\title{
DERIVING SPATIAL AND TEMPORAL PATTERNS OF COASTAL MARSH AGGRADATION FROM HURRICANE STORM SURGE MARKER BEDS
}

\author{
Joshua Hodge and Harry Williams \\ Department of Geography and the Environment \\ University of North Texas \\ Denton, TX 76203, U.S.A. \\ joshuahodge@my.unt.edu
}




\begin{abstract}
1 This study uses storm surge sediment beds deposited by Hurricanes Audrey (1957), Carla

2 (1961), Rita (2005) and Ike (2008) to investigate spatial and temporal changes in marsh

3 sedimentation on the McFaddin National Wildlife Refuge in Southeastern Texas. Fourteen

4 sediment cores were collected along a transect extending $1230 \mathrm{~m}$ inland from the Gulf coast.
\end{abstract}

5 Storm-surge-deposited sediment beds were identified by texture, organic content, carbonate

6 content, the presence of marine microfossils and ${ }^{137} \mathrm{Cs}$ dating. The hurricane-derived sediment

7 beds facilitate assessment of changes in marsh sedimentation from nearshore to inland locations

8 and over decadal to annual timescales. Spatial variation along the transect reflects varying

9 contributions from three prevailing sediment sources: flooding, overwash and organic

10 sedimentation from marsh plants. Over about the last decade, hurricane overwash has been the

11 predominant sediment source for nearshore locations because of large sediment inputs from

12 Hurricanes Rita and Ike. Farther inland, hurricane inputs diminish and sedimentation is

13 dominated by deposition from flood waters and a larger organic component. Temporal variations

14 in sedimentation reflect hurricane activity, changes in marsh surface elevation and degree of

15 compaction of marsh sediments, which is time-dependent. There was little to no marsh

16 sedimentation in the period 2008-2014, firstly because no hurricanes impacted the study area and

17 secondly because overwash sedimentation prior to 2008 had increased nearshore marsh surface

18 elevations by up to $0.68 \mathrm{~m}$, reducing subsequent inputs from flooding. Marsh sedimentation rates

19 were relatively high in the period 2005-2008, averaging $2.13 \mathrm{~cm} / \mathrm{yr}$ and possibly reflecting

20 sediment contributions from Hurricanes Humberto and Gustav. However, these marsh sediments

21 are highly organic and largely uncompacted. Older, deeper marsh deposits formed between 1961

22 and 2005 are less organic-rich, more compacted and have an average annual sedimentation rate 
23 of $0.38 \mathrm{~cm} / \mathrm{yr}$, which is closely comparable to long-term sedimentation rates in similar marsh

24 settings nearby. These results demonstrate the utility of using hurricane storm surge marker beds

25 to investigate marsh sedimentation, provide insights into the sedimentary response of coastal

26 marshes to hurricanes and provide useful guidance to public policy aimed at combating the

27 effects of sea-level rise on coastal marshes along the northern Gulf of Mexico.

28 KEYWORDS: sediment accretion, sedimentation rate, sea level rise, overwash, washover,

29 Hurricane Audrey, Hurricane Carla, Hurricane Rita, Hurricane Ike.

30

31

32

33

34

35

36

37

38

39

40

41

42

43

44

45 
INTRODUCTION

Coastal marshes along the northern Gulf of Mexico provide valuable habitats for a variety of

flora and fauna, and serve to protect areas further inland by acting as buffers against storms

49 (Mitsch and Gosselink, 1984; Kennish, 2001; Turner et al., 2006; Yuill et al., 2009; Gedan, et al.,

50 2011; Tweel and Turner, 2014). Rising sea-level caused by thermal expansion of seawater due to

51 increasing global temperatures, regional subsidence due to groundwater extraction, and lack of

52 riverine sediment inputs to fill growing accommodation space, threaten to convert coastal

53 marshes to open water with the consequent loss of valuable marsh functions (DeLaune et al.,

54 1994; Kennish, 2001; Glick et al., 2013; Kent and Dokka, 2013). Rates of northern Gulf of

55 Mexico marsh loss have been dramatic - between 1955 and 1978 the loss of marshes was 127

$56 \mathrm{~km}^{2}$ per year - equivalent to the area of Rhode Island every 21 years (Turner, 1997). Blum and

57 Roberts (2009) estimate that in the absence of sediment input an additional $10,000-13,500 \mathrm{~km}^{2}$

58 of Mississippi delta plain marshes will be submerged by the year 2100 owing to subsidence and

59 sea-level rise.

60 Aggradation of coastal marshes by influx and deposition of inorganic sediment counters

61 declining relative elevation due to subsidence and sea-level rise. DeLaune et al., (2003)

62 demonstrated that diversion of Mississippi River waters into adjoining marshes provided

63 freshwater and sediment inputs that lowered salinity and enhanced marsh accretion and stability.

64 Roberts et al., (2015), working on marshes between the Wax Lake Outlet and the Lower

65 Atchafalaya River in Louisiana, found that the passage of cold fronts raised water levels by up to

$661 \mathrm{~m}$ and reversed normal river discharge into Atchafalaya Bay, causing overbank flooding into

67 adjoining coastal plain marshes. They found that deposition of suspended sediment carried in 
68 floodwaters resulted in $>1 \mathrm{~cm} /$ year of fine-grained sedimentation in streamside locations up to

$69100 \mathrm{~m}$ from channels.

Hurricane storm surges represent another mechanism for transport of sediment into marshes.

71 Williams (2012) found that Hurricane Ike (U.S. landfall September 13, 2008) deposited 16.2

72 million tonnes of sediment into marshes along $160 \mathrm{~km}$ of coastline in Texas and Louisiana. The

73 storm surge-derived sediment bed was up to $0.85 \mathrm{~m}$ thick and extended up to $3.6 \mathrm{~km}$ inland. A

74 number of other studies have also documented the contribution of hurricanes to aggradation of

75 coastal marshes (Mitsch and Gosselink, 1984; Nyman et al., 1995; Stone et al., 1997; Liu, 2004;

76 Törnqvist et al., 2006; Turner et al., 2006; Williams \& Flanagan, 2009; Boldt et al., 2010;

77 Williams, 2010; 2011; Tweel and Turner, 2012, 2014; Williams and Denlinger, 2013).

78 Hurricanes can deposit sediment on marshes along long sections of coasts and in locations

79 that are remote from significant riverine sediment sources (Williams, 2012). Hurricane storm

80 surges, combined with wind-driven waves, erode and entrain sediment from offshore, intertidal

81 flats, bays, beaches and dunes, and transport sediment, usually as a combination of traction load

82 and suspended load, into marsh interiors (Williams, 2010). Although hurricane storm surge

83 deposition often occurs on marshes paralleling the Gulf Coast, sedimentation also occurs on

84 marshes surrounding inland lakes and bays, such as Lake Pontchartrain, Louisiana (Liu et al.,

85 2014; Naquin et al., 2014).

86 Some coastal marshes experience increased aggradation even as sea-level rise

87 accelerates, due to biotic processes such as the $\mathrm{CO}_{2}$ fertilization effect and the stimulation of

88 increased above-ground and below-ground biomass production. Increased above-ground

89 biomass production may also increase inorganic sedimentation because of enhanced trapping of

90 suspended sediment from tidal flood waters; although if sea-level rise accelerates beyond a 
91 critical threshold, plant dieback and marsh loss can still occur (Cherry et al., 2008; Hill and

92 Anisfeld, 2015; Ratliff et al., 2015). In contrast, the permanent inundation and conversion to

93 open water of large areas of marsh in the Mississippi delta plain following reductions in

94 Mississippi River suspended sediment inputs, shows that other marshes are sediment-limited and 95 dependent on sufficient inorganic sediment inputs to keep pace with accelerated sea-level rise

96 (Day et al., 2000; Blum and Roberts, 2009).

97 Tropical cyclones often result in net gains of sediment for marshes subjected to storm

98 surge overwash, counteracting the relative elevation loss from sea-level rise (Stone et al., 1997;

99 Cahoon, 2006; Turner et al., 2006; McKee and Cherry, 2009; Williams, 2012). Consequently, it

100 is important to gain a better understanding of the contributions and consequences of tropical

101 cyclone storm surge deposition to coastal marsh aggradation. Better understanding of tropical

102 cyclone-derived sedimentation could have important consequences for coastal management

103 agencies that build and maintain seawalls, levees, bulk-heads, dikes, weirs, piers, docks,

104 pipelines, dams and other hard structures, which act as physical barriers to storm surges and may

105 inhibit inorganic sediment accretion on marsh surfaces (Deegan et al., 1984; Sasser et al., 1986;

106 Swenson and Turner, 1987; Delaune et al., 1989; Turner, 1990; White and Morton, 1997; Bryant

107 and Chabreck, 1998; Kennish, 2001).

108 Williams (2010) documented Hurricane Ike storm surge sedimentation on the McFaddin

109 Wildlife Refuge in southeastern Texas in January 2009, four months after the hurricane made

110 landfall. Along a $1230 \mathrm{~m}$-long transect of thirteen trench locations, the storm surge deposit was

111 found to exhibit two distinct styles of sedimentation: a sandy washover fan, up to $0.64 \mathrm{~m}$ in

112 thickness, extending about $150 \mathrm{~m}$ inland and bounded by an avalanche face, deposited as traction 
113 load; and a thinner, finer, more organic-rich blanket of sediments extending several km inland,

114 deposited from suspension (Fig. 1).

\section{a}

116 Figure la. View to northwest across surface of a sandy washover fan deposited by Hurricane Ike

117 in January, 2009 (viewpoint is near core location 1 on Fig. 3). The fan was approximately $0.6 \mathrm{~m}$

118 thick at this location and was almost entirely devoid of vegetation at this time. Standing

119 vegetation is visible beyond the edge of the washover fan, in the vicinity of core site 4. $b$.

locations). The storm surge deposit, consisting of about $3 \mathrm{~cm}$ of sandy mud, has a sharp contact with underlying organic-rich marsh sediments. Stems of live marsh plants protrude through the storm surge deposit (arrowed).

\section{In 2011, a core obtained from the location of trench 5, $265 \mathrm{~m}$ inland, revealed three deeper} prominent sand beds, below the Hurricane Ike sand bed (Fig. 2). These sand beds appear to share many characteristics with the overlying Hurricane Ike deposit (higher sand content and lower organic content than enclosing marsh deposits; sharp basal contact) and are tentatively interpreted as hurricane storm surge deposits. 


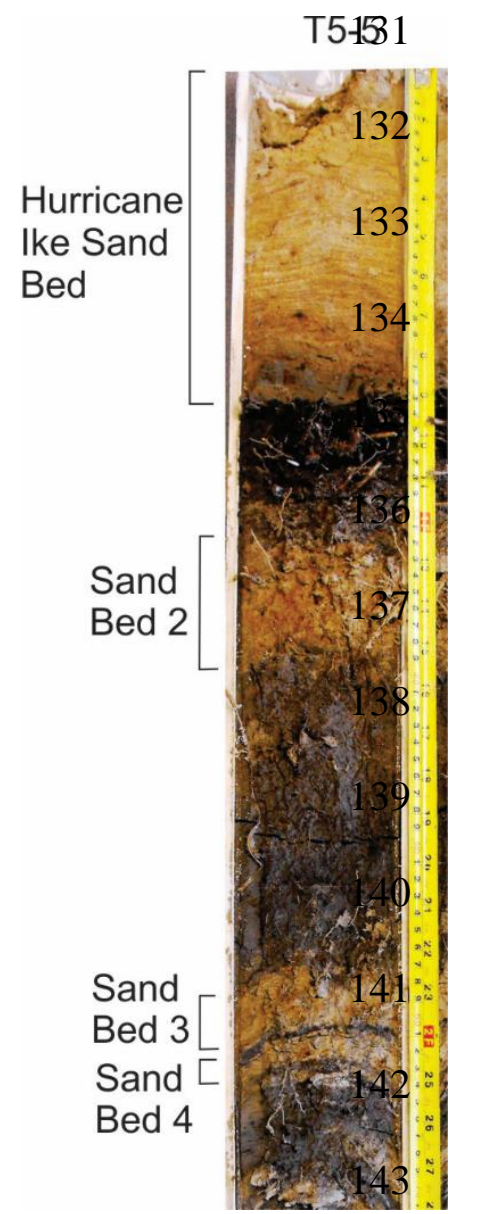

144 Figure 2. Core T5-5 obtained in 2011 from McFaddin National Wildlife Refuge showing sand

145 bed of Hurricane Ike (2008) and three deeper sand beds (Sand beds 2, 3 and 4) (Williams,

146 unpublished data; see Fig. 3 for core location).

This paper reports on a project that expands upon Williams' (2010) study by obtaining 149 sediment cores at the same thirteen trench locations used in the 2010 study, with the goal of 150 using hurricane storm surge marker beds to investigate changes in marsh sedimentation. The 151 objective of the study was to assess the contribution of hurricane storm surge sedimentation to 152 marsh aggradation and the effects of the abrupt elevation gain from storm surge deposition on 153 subsequent non-hurricane-related sedimentation. Information gained from this study provides 
154 insights into decadal-scale sedimentary response of coastal marshes subject to storm surge

155 deposition and useful guidance to public policy aimed at combating the effects of sea-level rise 156 on coastal marshes along the northern Gulf of Mexico coastline.

\section{STUDY AREA}

The study area is a transect of marshland located on the McFaddin National Wildlife 160 Refuge, a 23,820 hectare tract of marshes and lakes located in Jefferson County in the far

161 southeastern corner of Texas (Fig. 3). A wide sandy beach, backed by low discontinuous

162 foredunes, forms the boundary between the refuge and the Gulf of Mexico. Highway 87 runs

163 along the seaward edge of the refuge, but after repeated washouts caused by hurricanes, the

164 highway south from Clam Lake Road was closed in 1990.

165 Clam Lake is a tidally-influenced brackish lake having numerous connections via tidal 166 creeks and ditches to Sabine Pass and the Gulf Intracoastal Waterway, which forms much of the 167 northern boundary of the refuge. The lake, essentially at sea level, has the lowest elevation in the 168 study area. Elevation increases seaward along the transect from $0.3 \mathrm{~m}$ NAVD88 at core site 13 to $1691.72 \mathrm{~m} \mathrm{NAVD88}$ at core site 1. Adjacent to the transect, Highway 87 has an elevation of $1.47 \mathrm{~m}$ 170 NAVD88 (Fig. 3).

171 Flooding of marshes around the lake results from high discharges in the Sabine and Neches 172 rivers (which raises water levels in the Gulf Intracoastal Waterway, Sabine Lake and Sabine

173 Pass), heavy rain, high tides, storm surges and overwash. Marshes on the refuge range from

174 freshwater to brackish and are categorized as temporarily, seasonally or semi-permanently

175 flooded, depending upon subtle variations in elevation. In the study area, a narrow strip of marsh 176 at the seaward end of the transect is characterized as palustrine, emergent, intermittently flooded 
177 ( core sites 1-7) and the lower more landward marsh is characterized as estuarine, intertidal,

178 emergent, irregularly flooded ( core sites 8-13) (U.S. Fish and Wildlife Service, 2016) (Fig. 3).

179 The marshes are dominated by inorganic sediment. Williams (2010) found that the inorganic

180 sediment content of the 2008 marsh surface (pre-Hurricane Ike) at the 13 core sites along the

181 transect ranged from 67-95\% and averaged $85 \%$ (on a dry weight basis).
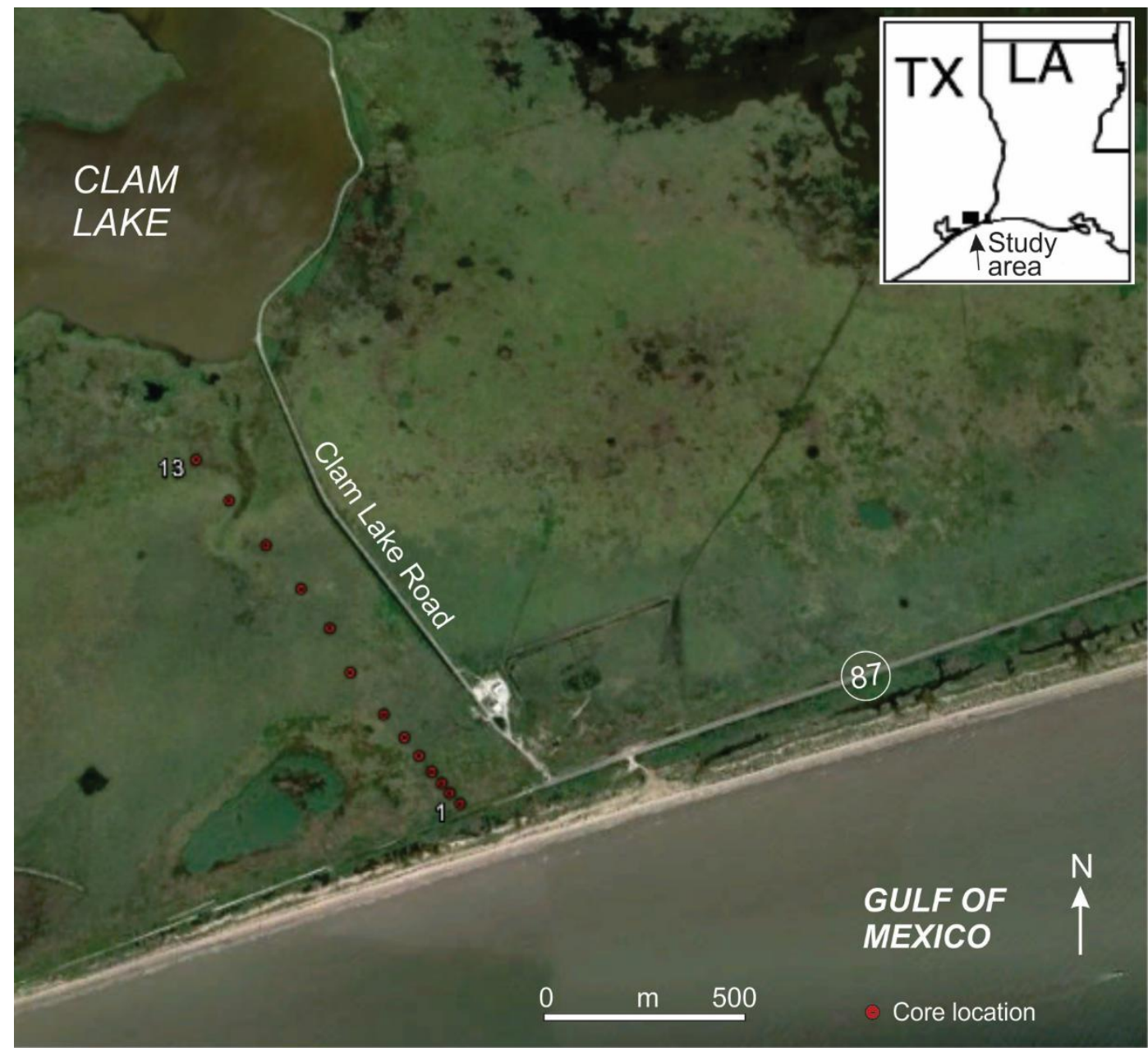

Figure 3. Study area at McFaddin National Wildlife Refuge, Texas. Core locations, numbered consecutively from 1 to 13, coincide with trench locations used in Williams' (2010) study. Core 
200 reached maximum heights of approximately $1 \mathrm{~m}$ above Highway 87. Although these dunes

201 formed a partial barrier to recent storm surge overwash, there were low spots in the dune line and

202 wide gaps in the dunes existed to allow vehicle access to the beach. In 2008, Hurricane Ike

203 generated an unusally large storm surge in the study area exceeding 4 m NAVD88, which

204 overtopped the foredunes, partially eroded them and completely inundated Clam Lake and

205 surrounding marshland.

\section{METHODS}

\section{Marsh Stratigraphy}

208 The thirteen trench locations used in Williams' (2010) study were relocated using a hand-

209 held GPS with reported accuracy of $\pm 10 \mathrm{~m}$ (Garmin, 2007). A core was obtained at each

210 location by driving aluminum or PVC tubes into the marsh, until resistance prevented further

211 penetration, typically at a depth of 50-100 cm. Compaction of cores was assessed by comparing

212 the depth of penetration of the coring tube and the distance between the top of the sediment core

213 inside the tube and the ground surface. This allowed compaction to be calculated as a percentage

214 of core length; compaction percentages varied from 2-25\%. Most compaction occurred in sand-

215 rich cores from the washover fan (cores 1-4, average compaction 19\%). This probably reflects

216 the greater resistance of these sediments to core penetration. Less compaction occurred in the

217 softer, wetter, less sand-rich cores farther inland (cores 5-13, average compaction 6\%).

218 Uncompacted depths within cores were estimated by applying the compaction percentage

219 uniformly over the entire length of the core. Although the compaction correction likely

220 introduced a small amount of error, stratigraphy does at least seem consistent between cores with

221 little compaction (e.g. core 6, 2\%) and cores with more compaction (cores 7 and 8, 4\% and 8\%

222 respectively). Cores were sealed and transported to the geomorphology laboratory at the 
223 University of North Texas, where the tubes were cut lengthwise and the sediment cores within

224 were split into two halves longitudinally. Cores were logged and photographed. Selected cores

225 were sampled at selected depths for textural analysis, loss-on-ignition (LOI) analysis and

226 foraminiferal analysis.

227

228 Marsh Topography

The elevation of each core site was measured by a level transit set up on Highway 87

230 near core site 1 , at core site 1 , at core site 8 and at core site 11 (four level sites were required to

231 cover the 1230 m-long transect). All elevations were tied to a USGS benchmark a few meters

232 north of Highway 87 in the vicinity of the study area (benchmark designation E1015, elevation

2331.54 m NAVD88; personal communication, R. Josey, Texas Department of Transportation,

234 August 14, 2015).

235

236 Sand Content, Organic Content and Carbonate Content

237 Sediment samples were collected from selected cores from within, below and above

238 suspected hurricane-storm-surge-deposited sediment beds for textural, Loss-On-Ignition (LOI)

239 and microfossil analyses to help document contrasts in lithology and microfossil content between

240 the sediment beds and the enclosing marsh sediments. Additional samples were taken from

241 sections of cores suspected to contain storm-surge-deposited sediment beds, but lacking in

242 visually distinct sand layers because of a lack of lithologic contrast and/or bioturbation.

243 All samples were divided into two subsamples for analysis. One subsample was weighed

244 and then oven-dried at $105^{\circ} \mathrm{C}$ for 24 hours to determine moisture content (\% wet weight). The

245 other subsample was weighed and then wet-sieved through a $63-\mu \mathrm{m}$ sieve to retain the sand 
246 fraction. The sand fraction was air-dried and weighed. The measured moisture content was used

247 to calculate the dry weight of the sieved sample, and the weight of the sand fraction was then

248 used to calculate sand content (\% dry weight). The dried subsample was weighed and then

249 placed in a muffle furnace at $550{ }^{\circ} \mathrm{C}$ for 4 hours to determine organic matter content (\% dry

250 weight). After reweighing, the same sample was returned to the muffle furnace for 2 hours at 950

$251{ }^{\circ} \mathrm{C}$ to determine carbonate mineral content (\% dry weight).

252 Loss on ignition (LOI) is a widely used technique to estimate the amount of organic

253 matter and carbonate mineral content in sediments (Dean, 1974). The LOI technique has sources

254 of potential error related to variations in sample size, sample composition, furnace temperature,

255 furnace exposure time and furnace position. LOI results may vary, for example, due to

256 dehydration of clay minerals or insufficient furnace temperatures and exposures times (Heiri et

257 al., 2001). These limitations decrease the effectiveness of LOI as a quantitative tool, but LOI

258 results correlate well to results gained from other standard techniques, allowing the use of LOI as

259 a qualitative method (Beaudoin, 2003; Santiseban et al., 2004). LOI procedures used in this study

260 follow the recommendation of Heiri et al. (2001) for consistency; all samples had uniform

261 treatment in terms of sample size, furnace temperatures and furnace exposure times.

263 Microfossil Analysis

264 Sand fractions derived from wet sieving were examined under a dissecting microscope to

265 identify and count foraminifers. If the sand fraction was small $(<1 \mathrm{~g})$, the entire sample was

266 examined for foraminifers; if the sand fraction was large (>1 g), a dry splitter was used to obtain

267 a subsample (typically $0.2-0.5 \mathrm{~g}$ ) for analysis and foraminiferal counts were multiplied

268 accordingly to estimate the number of specimens in the entire sample. Foraminifers were 
269 identified to the genus or species level and the percentage of calcareous and agglutinated species

270 in each sample was calculated. The total number of foraminifers in the sample was used to

271 calculate the number of foraminifers per gram of dry sediment.

\section{RESULTS}

\section{Marsh Stratigraphy and Identification of Storm-Surge-Deposited Sediment Beds}

276 and was visually identifiable in all fourteen cores (Fig. 4). This sediment bed thins and fines

277 inland; its thickness and texture closely matches descriptions made by Williams (2010) shortly

278 after the hurricane's landfall in 2008. Hurricane Ike's deposit provides a modern analog to aid in

279 identification of older storm surge sediment beds deeper within the marsh. Older sediment beds

280 were readily identifiable in many cores because they are visually distinct, relatively thick, sandy,

281 have sharp basal contacts and contrast lithologically with enclosing finer-grained, more organic-

282 rich marsh sediments. Farther inland, the storm surge deposits become thinner, more

283 lithologically similar to enclosing marsh sediments and more bioturbated (Fig. 4).

284 Four distinct sediment beds are visible in core T5-5, including Hurricane Ike's deposit at 285 the top of the core (Figs. 2, 4). A relatively thick, sandy sediment bed (sand bed 2) is apparent a 286 short depth below the Hurricane Ike deposit and two thinner, closely-spaced, but distinctly 287 separate, sediment beds are visible near the bottom of the core (beds $3 \& 4$ ). These two sediment 288 beds are separated by a thin layer $(\sim 5 \mathrm{~mm})$ of marsh sediment. The same four sediment beds are 289 recognizable in cores 6 and 9. In core 9, a sandy sediment bed a short depth below Hurricane 290 Ike's deposit is recognizable, but appears heavily disturbed by bioturbation; in core 6, the two 291 deeper sediment beds (beds 3 \& 4) also appear disturbed by bioturbation, but they are still 
292 recognizable as distinct sediment beds, separated by a thin layer of marsh deposits. In core 7, all 293 three sediment beds (beds 2, 3 \& 4) appear to have been disturbed by bioturbation, to the extent 294 that the two deeper sediment beds have apparently become mixed into a single sandy layer. In

295 core 8 , the two deeper sediment beds (beds $3 \& 4$ ) are recognizable and separated by marsh 296 deposits, but sediment bed 2, immediately below Hurricane Ike's deposit, is not visible. In cores 297 10-13 there are no visually recognizable sediment beds below the Hurricane Ike deposit (Fig. 4). 

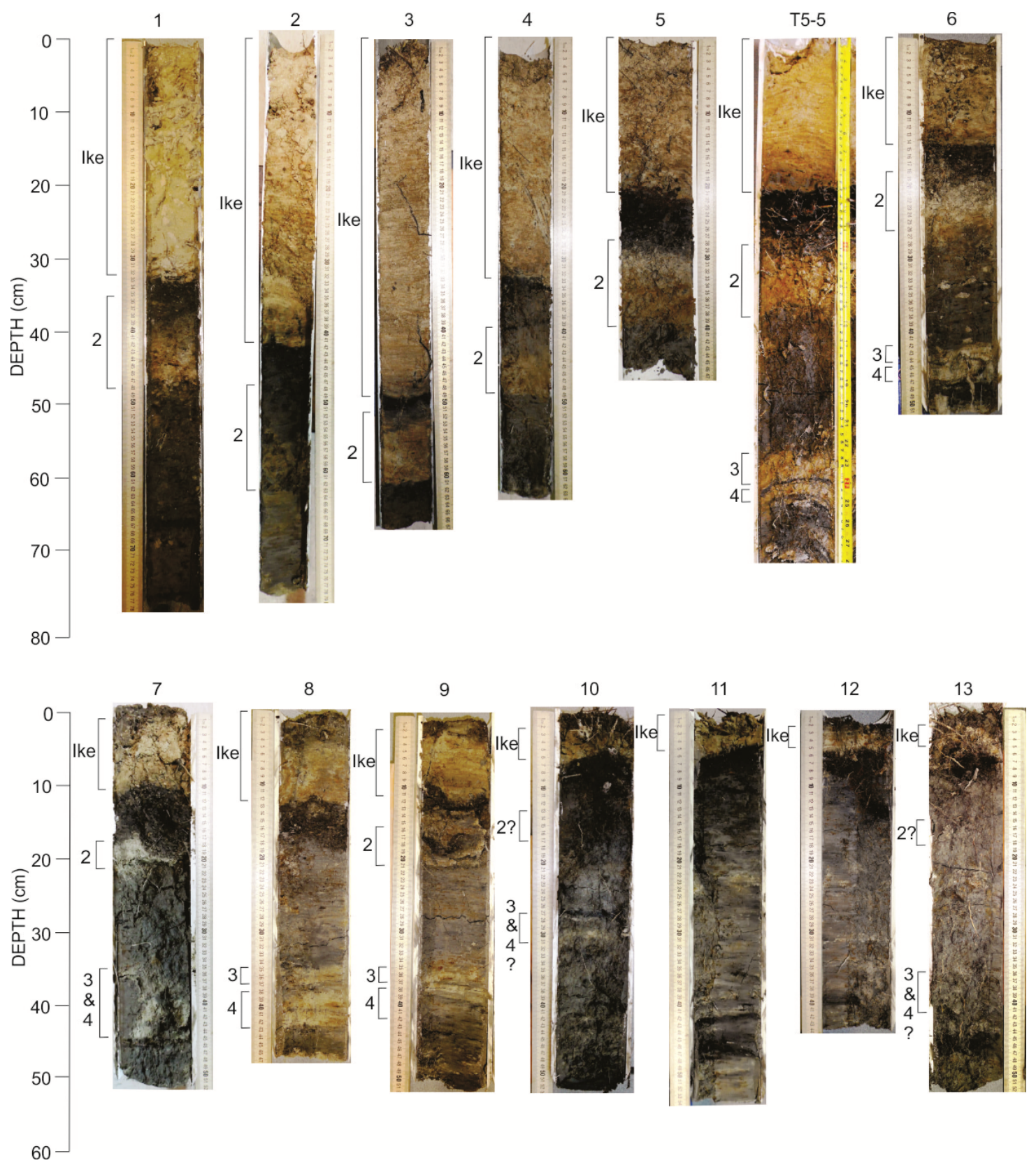

$300 \quad$ Figure 4. Storm surge sediment bed deposited by Hurricane Ike (2008) and other sediment beds

301 of suspected hurricane-storm-surge origin (beds 2, 3 and 4) in cores from McFaddin National

302 Wildlife Refuge. Storm surge deposits that are not visually distinct but are identified by LOI

303 analysis are followed by a question mark. Some of the bed 2 deposits include a "mud cap."

304 Cores 1-13 were obtained in 2014; core T5-5, from the same location as core 5, was obtained in 3052011 (Williams, unpublished data, 2011). 

organic\% and carbonate $\%$ ) were examined in an attempt to identify sediment beds that were not

310 visually recognizable in cores (Fig. 5).

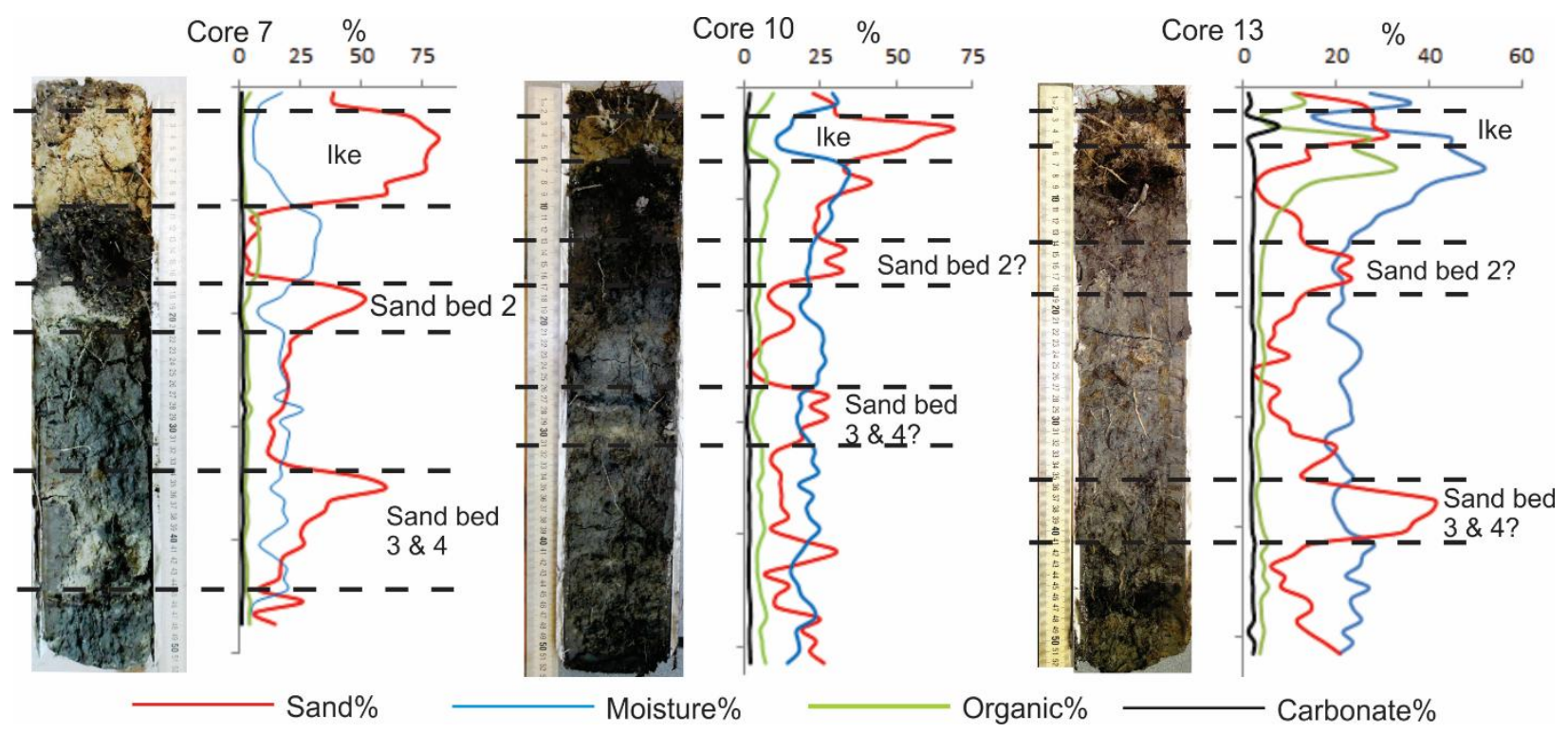

Figure 5. LOI analysis results for cores 7, 10 and 13. Core 7 is included to illustrate the LOI

313 signature of known (visually recognizable) storm surge sediment beds (elevated sand\%, reduced 314 moisture\% and reduced organic\%; carbonate\% varied little throughout most cores and did not 315 help in interpretation).

318 surge sediment beds, only in cores 10 and 13. The sand-rich zones a short depth below Hurricane

319 Ike's storm surge deposit in both cores are assumed to be sediment bed 2 and the deepest sand-

320 rich zones in cores 10 and 13 are assumed to be the result of mixing of the closely-spaced 
321 sediment beds 3 and 4 by bioturbation. These presumably bioturbated storm surge sediment

322 beds have been indicated on Fig. 4.

323 Foraminiferal analysis did not reveal any additional bioturbated sediment beds within the

324 cores. Samples were examined from selected depths in cores with the aim of identifying

325 calcareous foraminifers presumably transported inland by hurricane storm surges, as had been

326 shown to be the case for Hurricane Ike (Williams, 2010). However, the majority of samples

327 examined were either entirely barren or contained low numbers of agglutinated marsh

328 foraminifers, which are presumably in-situ and do not indicate landward transport of marine

329 sediment. The only exception was core 4, where samples from the base of the Hurricane Ike sand

330 bed, the underlying marsh deposits and the sand bed below Hurricane Ike's, contained

331 moderately large numbers of calcareous and agglutinated specimens (Table 1; Fig. 6).

332 It is notable that Williams (2010) also found large numbers of foraminifers at core site 4.

333 In the 2010 study, 1661 foraminifers per gram of dried sediment, $98 \%$ calcareous forms, were

334 found in the base of Hurricane Ike's storm surge deposit at trench site 4 - more than at any of the

335 other 12 trench locations along the transect, where foraminiferal concentrations varied from 85 to

3361058 specimens per gram of dried sediment. The spike in foraminiferal concentration at this

337 location may be related to the effects of the topographic step at the landward edge of the

338 washover fan and the presence of standing vegetation beyond the edge of the washover fan on

339 the hydrodynamics of storm surge deposition; for example, foraminifers in suspension may be

340 winnowed out and deposited where there is a substantial reduction in flow energy (Williams,

341 2010; Fig. 1a).

342 The virtual absence of foraminifers, particularly calcareous forms, in the majority of

343 samples examined suggests that foraminiferal tests are poorly preserved in the marsh. This 
344 supports Williams' (2010) contention that foraminifers are poorly preserved in nearby Clam

345 Lake (Fig. 3) and is consistent with the substantial reduction in foraminiferal concentrations in

346 the base of the Hurricane Ike deposit at core site 4 - from 1661 specimens per gram of dried

347 sediment in January 2009 to 543 specimens per gram of dried sediment in August 2014 (Table 1;

348 Fig. 6).

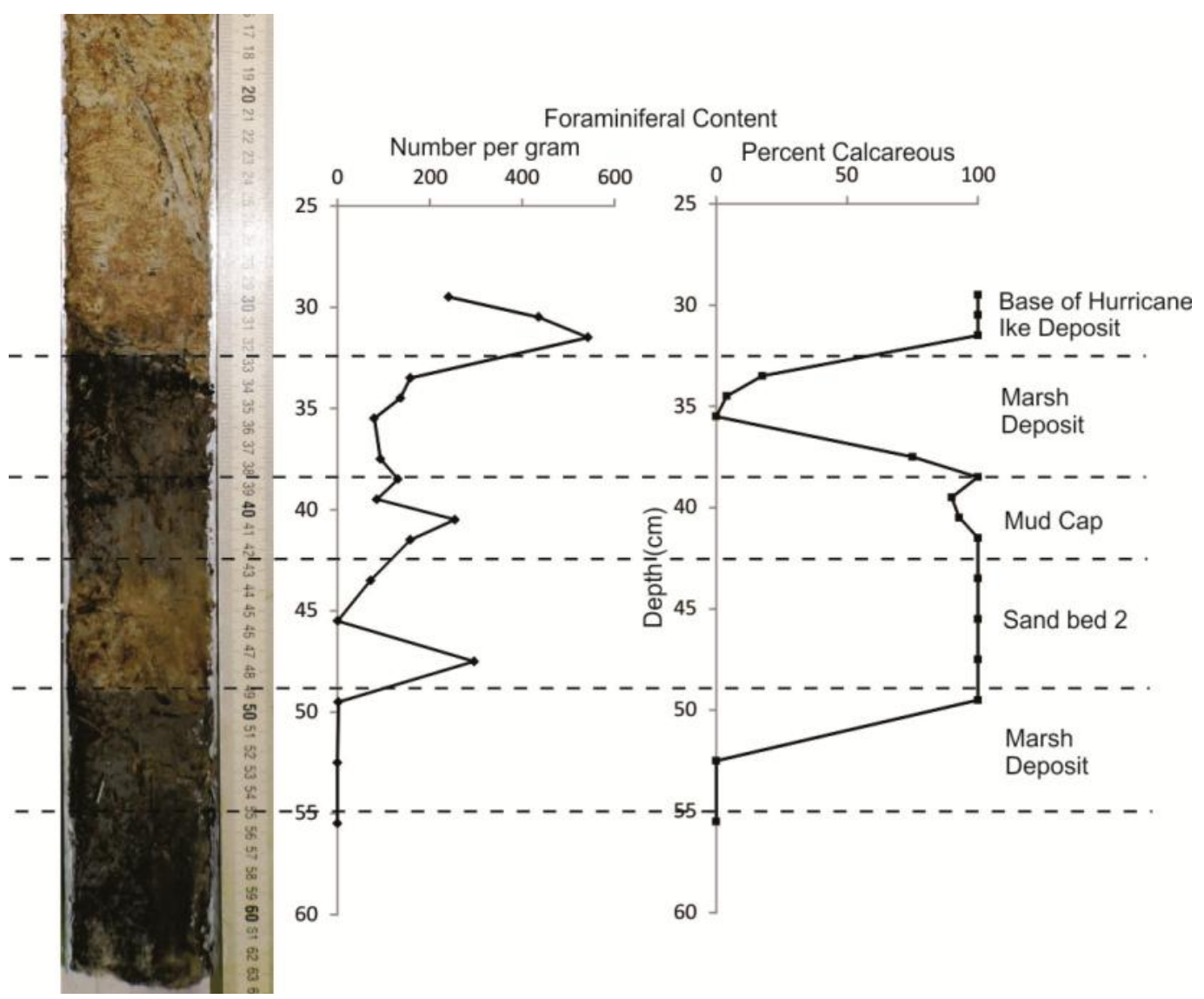

350 Figure 6. Foraminiferal content of core 4. Foraminifers are abundant and almost entirely

351 calcareous marine forms in the storm surge sediment beds. Lower numbers of agglutinated

352 marsh forms are present between the storm surge deposits, recording marsh sedimentation.

The distribution of foraminifers in core 4 also indicates the presence of a "mud cap" on top of sand bed 2. This part of the core is visually distinct from, and finer than, the underlying 
356 sand bed (although still $\sim 50 \%$ sand in the case of core 4 ), but it contains abundant calcareous

357 foraminifers, showing it is part of the storm surge deposit (Fig. 6). Although not as distinctive as

358 underlying sand beds, mud caps are visually apparent in several other cores and have LOI

359 signatures that contrast to overlying marsh deposits; most notably, lower organic and moisture

360 contents and, in most cases, elevated sand contents (Fig. 7). It is assumed that these mud caps

361 were deposited from suspension onto parts of the marsh where ponded flood waters remained for 362 one to several days following passage of the hurricane. Similar mud caps have been reported for

363 Hurricane Rita deposits in Louisiana (Williams, 2009, 2011; Freeman et al., 2015) and in

364 southeastern Texas (Crosby and Reece, 2009). Mud caps are included in some of the sediment 365 bed 2 deposits shown in Fig. 4.

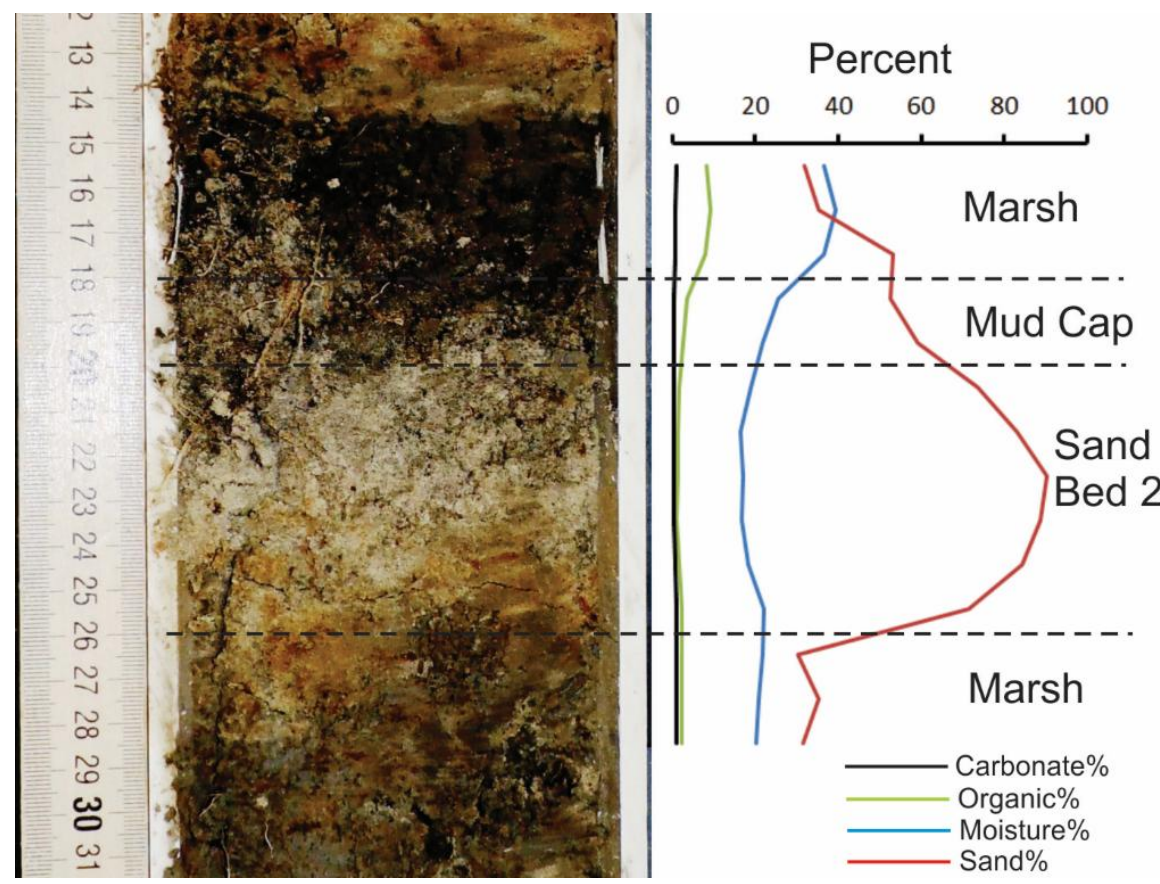

367 Figure 7. LOI characteristics of a mud cap on sand bed 2 in core 6. The 'mud cap' has lower

368 organic and moisture contents than overlying marsh deposits. The mud cap presumably was

369 deposited from suspension and is considered part of the storm surge deposit. 


\section{DISCUSSION}

372 Age and Origin of Storm Surge Sediment Beds.

The presence of abundant calcareous foraminifers in sand bed 2 confirms a marine origin

374 for this sand layer. Significant numbers of foraminifers were not found in sand beds 3 or 4 in any

375 of the cores. Given that Williams (2010) found marine calcareous foraminifers in all 13 cores

376 collected from Hurricane Ike's storm surge deposit four months after landfall (i.e. foraminifers

377 are apparently common in freshly-deposited storm surge deposits at this site), the lack of

378 foraminifers probably reflects poor preservation of foraminifera tests in these older deposits.

379 However, the similarities between all four sand beds - they are sand-rich, they thin and fine

380 landward, they have sharp basal contacts and they extend over 1,000 m inland - strongly

381 suggests they are hurricane storm surge deposits. Tsunamis can also deposit sand sheets in

382 marshes, but there is no historical record of a tsunami strike in the northern Gulf of Mexico.

383 There is no evidence that lower-intensity storms deposit extensive sand sheets over the surface of

384 the marsh and no other known mechanisms can account for these deposits.

A means of estimating the age of the two oldest storm-surge-deposited sediment beds

386 (sand beds 3 and 4) is provided by Williams and Denlinger (2013), who conducted ${ }^{137}$ Cs dating

387 of marsh sediment underlying the Hurricane Ike storm surge deposit at core site 3. Commonly,

388 this technique is based on the identification of a peak in ${ }^{137} \mathrm{Cs}$ concentration corresponding to the

389 year 1963, after which the Nuclear Test Ban Treaty was implemented, greatly reducing

390 atmospheric fallout from above-ground nuclear weapons testing (Gustafson, 1969). However,

391 many ${ }^{137} \mathrm{Cs}$ profiles from marshes in this area do not have an unambiguous ${ }^{137} \mathrm{Cs}$ concentration

392 peak. This includes the profile from core site 3 , which has high concentrations of ${ }^{137} \mathrm{Cs}$ at a

393 shallow depth (Fig. 8). This is a common finding in this area and probably results from erosion 
394 and re-deposition of ${ }^{137} \mathrm{Cs}$-rich sediments onto a more recent marsh surface (Williams and

395 Flanagan, 2009; Williams, 1995, 2011; Williams and Denlinger, 2013). Instead, dating is based

396 on the assumption that the depth at which the ${ }^{137}$ Cs concentration falls to zero corresponds to the

397 year 1950, which approximates the onset of large-scale above-ground nuclear weapons testing

398 and widespread fallout of atmospheric ${ }^{137}$ Cs (Milan, et al., 1995). On this basis, Williams and

399 Denlinger (2013) estimated that the surface of the marsh in the year 1950 is approximately $47 \mathrm{~cm}$

400 below the base of the Hurricane Ike deposit (Fig. 8).

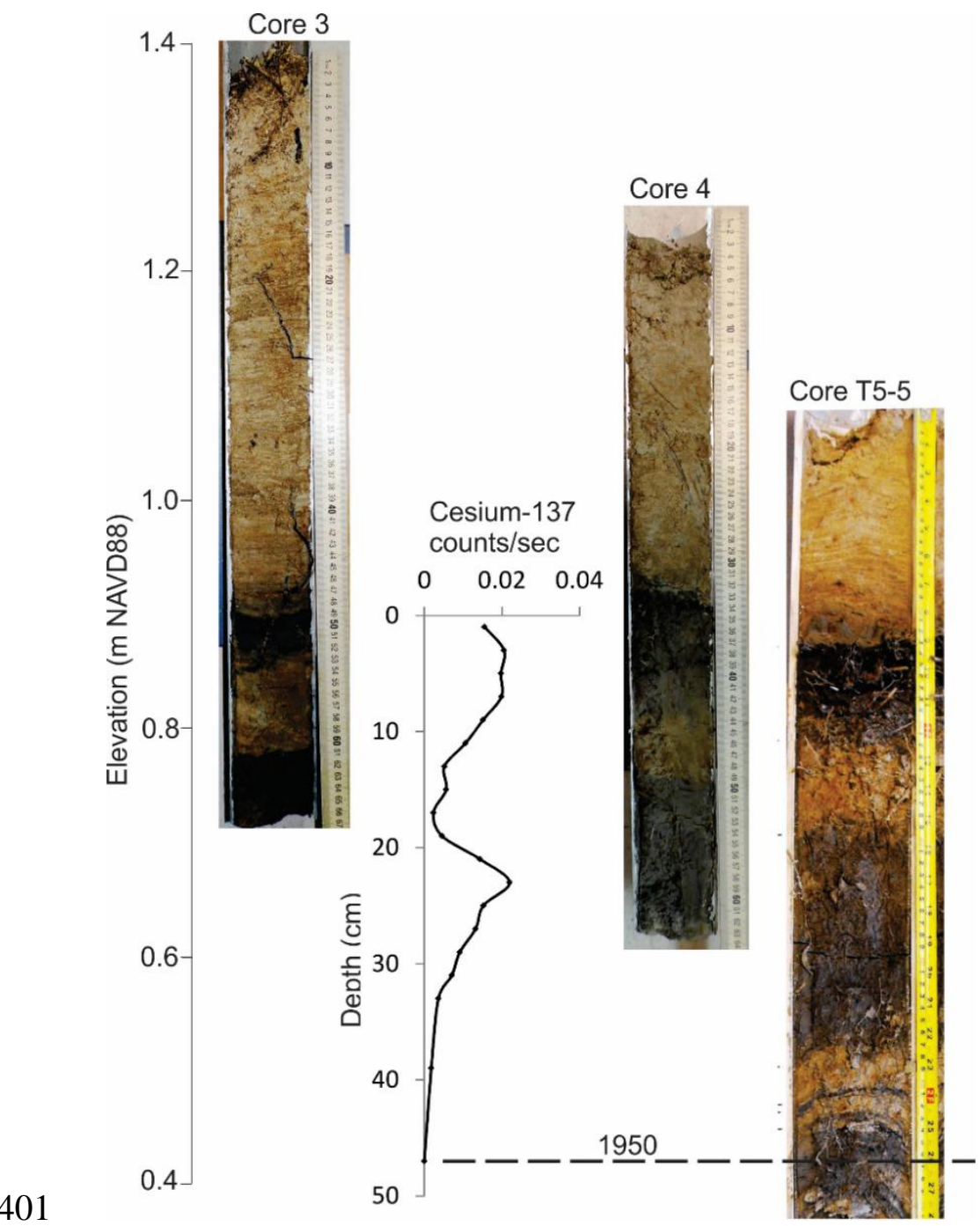

402 Figure $8 .{ }^{137}$ Cs concentration profile in sediments underlying Hurricane Ike's storm-surge

403 deposit at core site 3. The 1950 marker horizon is extended to core T5-5. Cores are shown at 
404 their correct elevation, but not their correct horizontal separation. ${ }^{137}$ Cs data from Williams and 405 Denlinger(2013).

406 Extending the 1950 marker horizon from core site 3 to core site T5-5, 90 m away, 407 suggests that sand beds 3 and 4 are a few $\mathrm{cm}$ above the level of the marsh surface in 1950 (Fig. 408 8). These two sand beds were probably deposited by hurricanes that occurred shortly after 1950. 409 Sand bed 2 is a relatively short depth below the Hurricane Ike deposit; it was probably deposited 410 shortly before 2008.

411 Twenty-three hurricanes passed within $300 \mathrm{~km}$ of the study area between 1950 and 2014 412 (Fig. 9). This radius was chosen because it encompasses Hurricane Carla (1961), which, 413 although making landfall $290 \mathrm{~km}$ to the west, generated a well-documented storm tide and 414 hurricane-force winds in the vicinity of the study area. In terms of wind speed, Hurricane Carla 415 was the most intense hurricane to make landfall on the Texas coast in the 20th century and the 416 9th most intense hurricane to affect the United States since 1851 (National Weather Service, 417 2011). In the study area, Hurricane Carla generated a 2.25-m storm tide and sustained winds of 41876 knots (Table 2).

419 Storm tide is the combined height of storm surge and tide level; this provides a better 420 indication of inundation potential than storm surge alone (i.e. a $1 \mathrm{~m}$ storm surge at low tide may 421 not cause inundation, whereas the same storm surge at high tide may lead to inundation). All 422 storm tides in Table 2 are referenced to NAVD88, which allows direct comparison of storm tide 423 height to the height of physical barriers, such as foredunes and Highway 87, and to the height of 424 the marsh surface. 


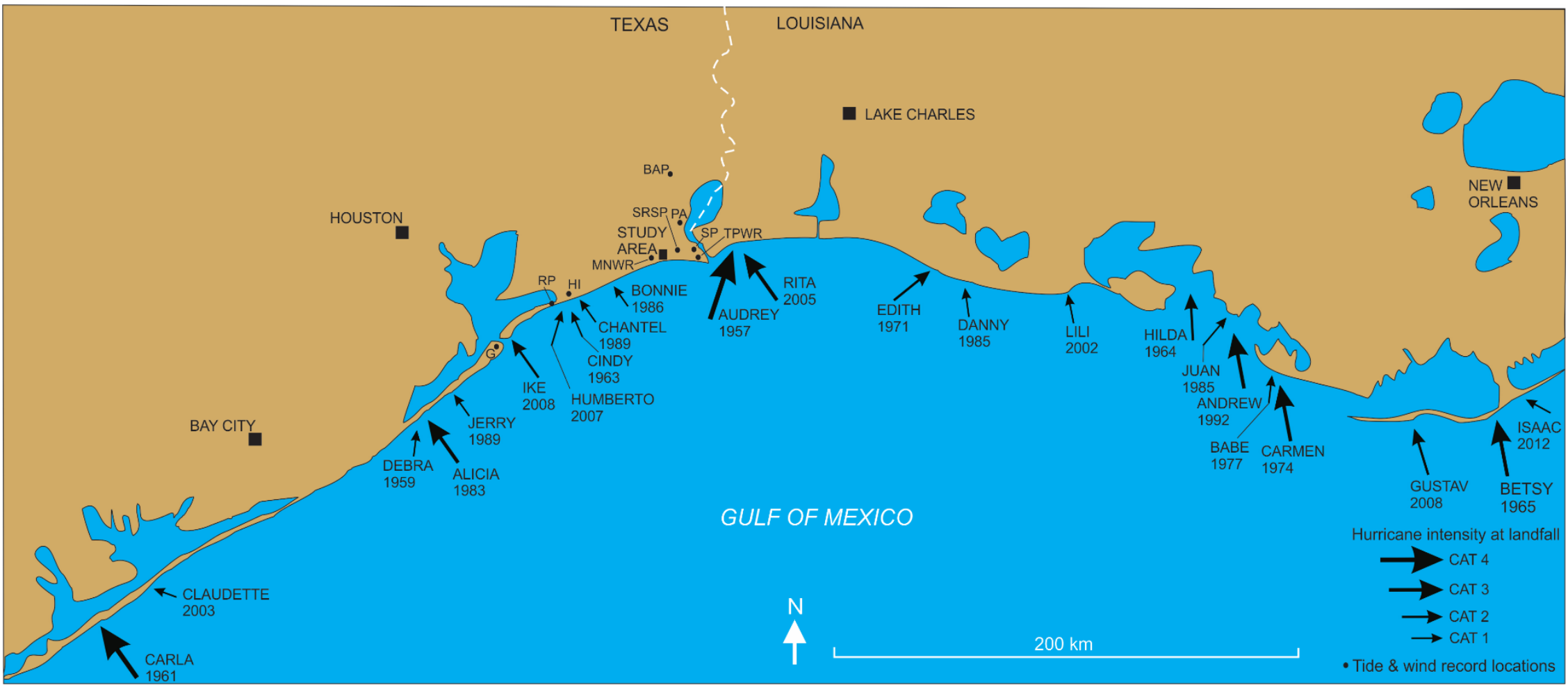

426 Figure 9. Map of hurricane landfalls within $300 \mathrm{~km}$ of study area and locations of tide and wind records. Location key: SP: Sabine

427 Pass, G: Galveston, PA: Port Arthur, BAP: Beaumont Air Port, HI: High Island, TPNWR: Texas Point National Wildlife Refuge,

428 MNWR: McFaddin National Wildlife Refuge, SRSP: Sea Rim State Park, RP: Rollover Pass. 
The largest storm tides and strongest sustained winds in the study area have been generated

432 by hurricanes of three kinds: very large and intense hurricanes that make landfall a considerable

433 distance to the west (e.g. Hurricane Carla); lower-intensity, but still powerful hurricanes that

434 make landfall a shorter distance to the west (e.g. Hurricane Ike); intense hurricanes that make

435 landfall a short distance to the east (e.g. hurricanes Audrey and Rita) (Table 2).

436 The importance of a landfall to the west or east of the study area results from the storm's

437 cyclonic circulation causing a larger storm surge in the right-front quadrant of the landfalling

438 hurricane (Liu, 2004). In this quadrant, onshore winds drive water against the coast causing a

439 large storm surge and large onshore waves: in the left-front quadrant, offshore winds greatly

440 reduce storm surge potential. This is why hurricanes Andrew, Carmen and Betsy had little to no

441 impact in the study area - they were intense storms, but made landfall a relatively large distance

442 to the east of the site (Table 2).

443 Other lower-intensity storms, such as hurricanes Bonnie and Humberto, even though making

444 landfall a short distance west of the study area, were not powerful enough to generate large storm

445 surges and strong sustained winds and, consequently, apparently did not deposit thick, extensive

446 sand-rich sediment layers over the marsh surface. These storms may have transported smaller

447 amounts of finer sediment into the marsh to form thinner, finer-grained, less extensive deposits;

448 if so, these deposits have presumably been mixed with marsh sediments by bioturbation and no

449 longer form recognizable storm surge sediment beds. A similar fate befell Hurricane Ike deposits

450 in a marsh in southwestern Louisiana; the hurricane formed a thin, muddy sediment bed that was

451 obscured by bioturbation within 20 months after landfall (Williams, 2011).

452 A combination of a large storm surge and large wind-driven waves are required to entrain

453 nearshore sediment and transport it onto a marsh (Williams, 2013). On this basis, it is likely that 
454 sand beds 2, 3 and 4 were deposited by hurricanes Rita, Carla and Audrey, respectively (Table

455 2). This interpretation is also consistent with the stratigraphic position of these sand beds with

456 respect to the ${ }^{137} \mathrm{Cs}$-derived 1950 marker horizon: it is plausible that sand bed 2, a short depth

457 below Hurricane Ike's deposit, could be the result of Hurricane Rita (2005), and that sand beds 3

458 and 4, a short distance above the 1950 marker horizon, could be the result of Hurricane Carla

459 (1961) and Hurricane Audrey (1957) (Fig. 8).

460 Additional support for this interpretation is provided by other studies of hurricane deposits

461 in this area: a sediment bed deposited by Hurricane Rita was found at Texas Point National

462 Wildlife Refuge, approximately $18 \mathrm{~km}$ east of the study area (Fig. 9). A survey of the marsh

463 made in November 2006, 14 months after landfall, revealed a sand-rich storm surge deposit at

464 the surface of the marsh. The deposit varied from 2 to $15 \mathrm{~cm}$ in thickness, extended at least 400

$465 \mathrm{~m}$ inland and, in places, was capped by clay, presumably deposited from suspension in standing

466 flood waters (Crosby and Reece, 2009). Williams (2011, 2013) documented storm surge

467 sediment beds deposited by hurricane Audrey and Rita in a marsh in southwestern Louisiana,

468 approximately $34 \mathrm{~km}$ east of the study area. Hurricane Audrey's storm surge deposit was

469 predominantly sand, thinned and fined inland, was up to $14 \mathrm{~cm}$ thick and extended over $400 \mathrm{~m}$

470 into the marsh. Hurricane Rita's deposit was up to $16 \mathrm{~cm}$ thick and extended over $800 \mathrm{~m}$ inland.

472 Spatial and Temporal Variations in Marsh Sedimentation

473 Identification of hurricane deposits dating from 1957, 1961, 2005 and 2008, provides a

474 means to assess both spatial and temporal variations in hurricane and non-hurricane marsh

475 sedimentation (Fig. 10). 


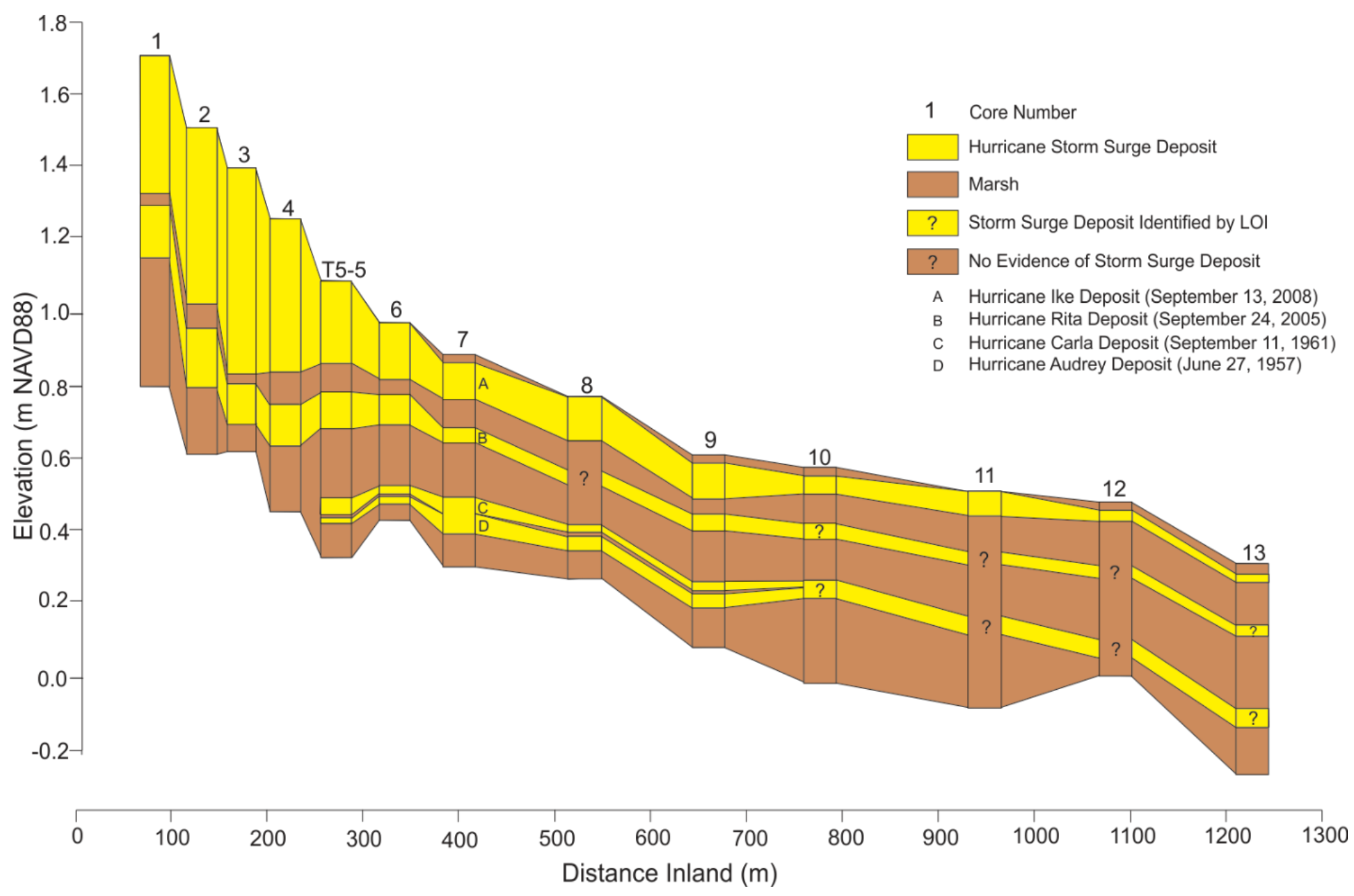

477 Figure 10. Stratigraphic section along transect, showing hurricane-storm-surge-deposited sand beds within marsh deposits. Core

478 lengths adjusted to remove compaction. Core 5 is not included because it is from the same location as core T5-5. 
Hurricane Ike's and Hurricane Rita's sediment beds clearly taper inland, most likely reflecting littoral sediment sources and deposition from a landward-directed surge of ocean water (Table 3). Both these storm surge-deposited sediment beds are thickest where washover fans 482 have formed (cores 1-4, Fig. 10; Fig. 1a). The washover fans are almost certainly traction load 483 deposits that built landward into the marsh during passage of the storm. Farther inland, the storm 484 surge deposits become finer-grained and more uniform in thickness and were probably deposited primarily from suspension (Williams, 2010).

Hurricane Carla’s and Hurricane Audrey’s sediment beds do not display a similar trend in thickness, probably because these sediment beds were only present in cores from the more distal part of the transect, beyond the likely extent of washover fans. It's likely that these sediment beds are present in the vicinity of cores 1-5, but at depths not reached by coring (Fig. 10). There 490 is also greater uncertainty in identifying the exact boundaries of these deposits in the cores; for 491 example, in several cores these sediment beds are bioturbated, probably resulting in an apparent 492 increase in thickness and, in cores 10 and 13, the boundaries of these sediment beds are only 493 tentatively identified by LOI analysis (Fig. 10; Table 3).

494 There are also apparent spatial trends in the thickness of marsh deposits between and above 495 the hurricane-deposited sediment beds (Figs. 10, 11; Table 3). No sediment had accumulated 496 above Hurricane Ike's sand bed at core sites 1-6 in the period 2008-2014. Farther inland, at lower 497 elevations, $\sim 1-2 \mathrm{~cm}$ of marsh sediment had accumulated at five of the remaining seven core sites 498 (Fig. 10; Table 3). Marsh sediment that formed between 2005 and 2008 (between deposition of 499 Hurricane Rita's and Ike's sand beds) shows a clear trend of increasing thickness in a landward 500 direction (Figs. 10, 11). Marsh sediment that accumulated after Hurricane Carla and before 501 Hurricane Rita (1961-2005) is more uniform, typically around 15-20 cm thickness, with no trend 
Hodge and Williams

Patterns of coastal marsh aggradation
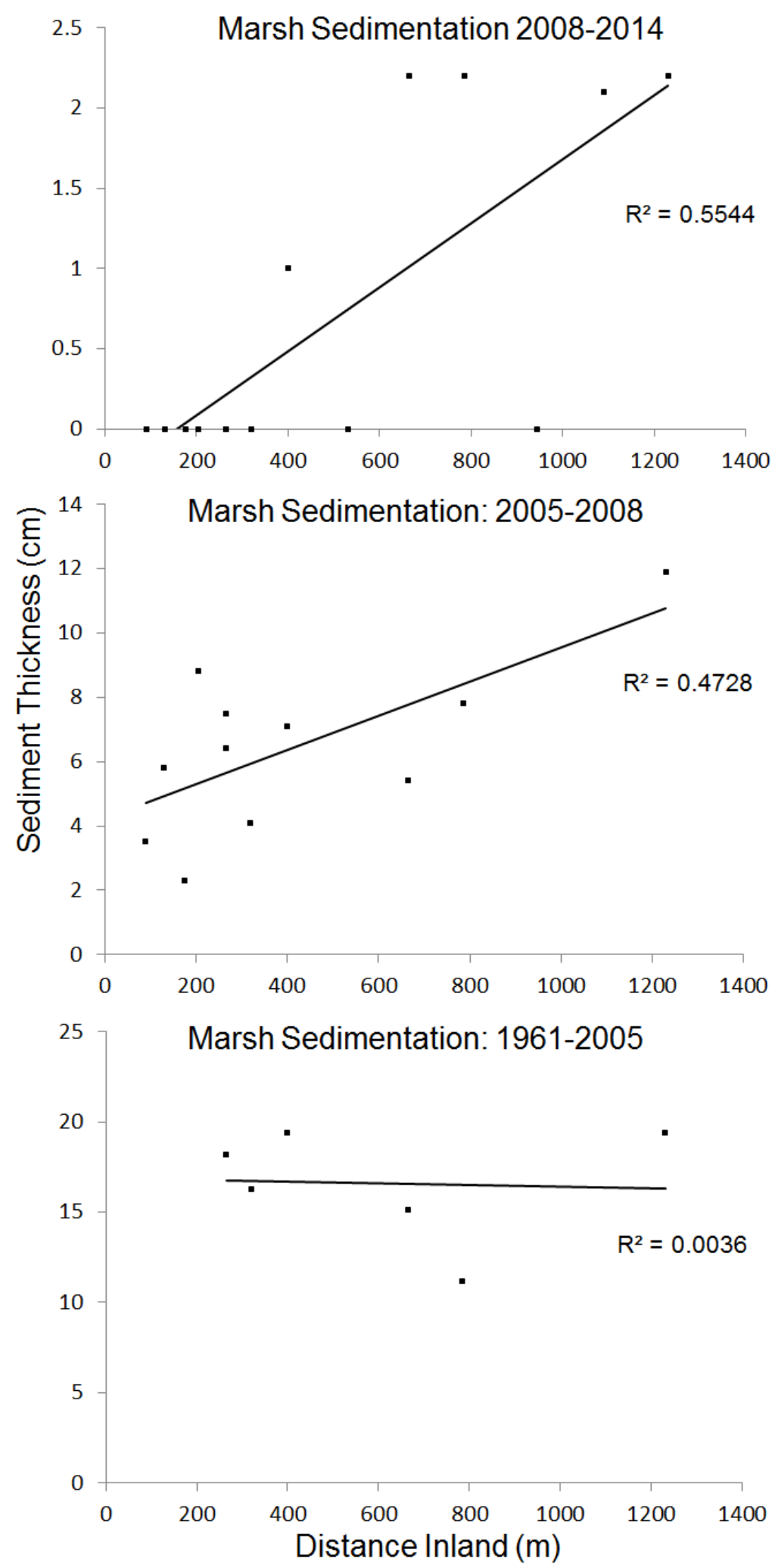

503 Fig. 11. Spatial trends in the thickness of marsh deposits along the core transect. 
505 with distance inland (Fig. 11). The amount of marsh sediment between Hurricane Audrey's and

506 Carla's sand beds (formed between 1957 and 1961) could only be discerned at four core sites,

507 varied between 0.5 and $1 \mathrm{~cm}$, and showed no apparent spatial trend (Fig. 10; Table 3).

508 Sediment sources for the marsh include flooding, overwash and organic sedimentation

509 from marsh plants. Flooding in the study area is caused by rising local water levels resulting

510 from high discharges in local rivers, heavy rain, high tides and storm surges (P. Walther, U.S.

511 Fish and Wildlife Service, personal communication, May 9, 2016). Flooding preferentially

512 delivers sediment to lower portions of the marsh, which are more frequently inundated and,

513 along the transect, are farther inland. Flooding also entails seaward transport of sediment along

514 the transect, as flood waters rise from lower, landward elevations, to higher, seaward elevations.

515 Some of the suspended sediment carried into the marsh by flood water presumably settles out

516 onto the marsh surface and some is likely trapped by the filtering effect of marsh vegetation.

517 When floodwaters (including storm surge flooding) recede, some suspended sediment is

518 probably carried back to lower elevations, but the overall effect of flooding is very likely a net

519 gain of sediment for the marsh.

520 Hurricanes Ike, Rita, Carla and Audrey all generated storm tides that were well above the 521 level of Highway 87 in the study area (1.47 m NAVD88) and, with the exception of the storm 522 tide of Hurricane Carla, may have overtopped foredunes (Table 2). In addition, all four storms 523 had strong sustained winds that probably generated large waves. The combination of waves and 524 storm tides likely caused widespread overwash and transported sediment hundreds of meters into

525 the marsh, forming the four sand beds. Lower intensity storms, in addition to causing storm 526 surge-related flooding of lower parts of the marsh, may also have caused small-scale overwash

527 and transported fine sediment landward into the marsh. Hurricanes Bonnie, Lili, Alicia and 
528 Humberto all generated storm tides that equaled or exceeded the height of Highway 87 in the

529 study area and probably caused overwash, at least where gaps in the dune line existed. In

530 addition, lower intensity storms, such as hurricanes Edith and Chantal, with storm tides below

531 the level of Highway 87 (Table 2), may still have caused overwash if accompanying waves were

532 sufficiently high to overtop the road.

533 It is notable that vegetation was slow to recover from the impact of Hurricane Ike on the

534 higher, drier parts of the transect, whereas dense vegetation continued to grow on the more

535 landward, lower and wetter parts of the transect (Fig. 1). Consequently, organic sedimentation

536 from in situ plant growth is a more important sediment source on lower more landward parts of

537 the transect; this is supported by Williams (2010) who found that the organic content of marsh

538 sediments markedly increased with distance inland along the transect.

539 Because marsh sediments along the transect are derived from both landward and seaward

540 sources, the relative contribution of each in any given time period, probably explains spatial

541 variations in marsh sedimentation. The abrupt jump in elevation along the seaward part of the

542 transect (core sites 1-6, Fig. 10), following deposition of Hurricane Ike's sand bed, probably

543 raised this part of the marsh above flooding levels during 2008-2014 and resulted in a lack of

544 flood-derived sedimentation. In the same period, no hurricanes impacted the study area, which

545 probably helped reduce flooding occurrence and resulted in a lack of overwash-derived

546 sedimentation. The slow recovery of vegetation on this part of the transect also appears to have

547 resulted in negligible organic sedimentation. The end result of this lack of sediment inputs was

548 that little to no sedimentation was recorded along the transect in the $\sim 6$-year period 2008-2014

549 (Table 3).

550 In contrast, between 2005 and 2008, the surface of the marsh along the transect was up to 
$551 \sim 56 \mathrm{~cm}$ lower (Table 3), increasing the likelihood of flood-derived sedimentation, which

552 presumably was of greater magnitude at lower elevations farther inland (Fig. 11). In the same

553 time period two hurricanes - Humberto and Gustav (Table 2) - and Tropical Storm Edouard

554 (Franklin, 2008) impacted the study area, possibly also resulting in flooding and some overwash-

555 derived sedimentation. Marsh sediment from this period also has a significant organic

556 component (Williams, 2010; Figs. 2, 5, 7). The combination of probable sediment inputs from a

557 seaward source (overwash), a landward source (flooding) and in situ plant growth, resulted in

558 considerable sedimentation along the entire transect, varying from 2.3 to $11.9 \mathrm{~cm}$ within this $\sim 3-$

559 year period (Table 3).

560 Between 1961 and 2005, the marsh aggraded at a relatively uniform rate along the transect,

561 with no apparent spatial trend (Fig. 11; Table 3). This suggests a balance between seaward

562 (overwash) and landward (flooding) sediment sources, as well as inputs of organic sedimentation

563 from local plants, along the entire transect. A large number of lower-intensity storms, for

564 example Hurricanes Bonnie (1986) and Lili (2002), impacted the study area in this 44-year

565 period, generating elevated water levels and strong winds (Table 2). These storms probably

566 contributed sediment to the marsh via flooding and, possibly, overwash, although none of them

567 formed a preserved, visually-recognizable sand bed within the marsh. It is likely that any storm-

568 surge sediment bed resulting from these storms has been mixed into marsh deposits by

569 bioturbation.

570 Average annual marsh sedimentation rates, derived from the thicknesses of marsh deposits

571 shown in Table 3, reveal large temporal variations in sedimentation (Table 4). Average

572 sedimentation rates are low in the period 2008-2014 when a combination of increased marsh

573 surface elevation and a lack of large storms decreased both overwash- and flooding-sourced 
574 sediment inputs. There is a considerable contrast in sedimentation rates between the period 2005-

5752008 , with sedimentation averaging $2.13 \mathrm{~cm} / \mathrm{yr}$, and the earlier periods 1961-2005 and 1957-

5761961 , when sedimentation averaged $0.38 \mathrm{~cm} / \mathrm{yr}$ and $0.16 \mathrm{~cm} / \mathrm{yr}$, respectively (Table 4).

577 It is very likely that these large differences in sedimentation rates are a reflection of the 578 degree of compaction of the marsh sediments. Marsh deposits formed between 2005 and 2008

579 are relatively uncompacted and highly organic; in many cores abundant large stems and roots are 580 visible, and the deposits have an open structure with large air pockets (for example, see core T5-

5815 in Fig. 2). Deeper in the cores, marsh deposits appear much more compacted; large organic

582 fragments and air pockets are not visible. This is supported by LOI results, for example in core

58310 organic content of marsh deposits is $\sim 10-11 \%$ at a depth of $7-9 \mathrm{~cm}$ (just below Hurricane

584 Ike's sand bed), but falls to $\sim 3-5 \%$ at depths of 30-32 cm, just below Hurricane Audrey's sand

585 bed (Fig. 5). These results suggest increasing compaction with age and depth within the marsh,

586 as organic matter is compressed, decomposes and air and water are removed from sediments by

587 progressively increasing burial pressure (Brain et al., 2012).

$588 \quad$ These findings are supported by a study of compaction and sedimentation of marsh

589 sediments in nearby Trinity Bay, Texas (Williams, 2003). At nine core sites in the Trinity Bay

590 marsh, autocompaction of marsh sediments was found to continue to depths of up to $166.5 \mathrm{~cm}$.

591 Compaction increased the bulk density of sediments at depth within the marsh by an average of

$592 \sim 400 \%$. Average annual sedimentation rates in the marsh, derived from ${ }^{137} \mathrm{Cs}$ dating, which

593 integrates several decades of sedimentation, averaged $0.37 \mathrm{~cm} / \mathrm{yr}$ at nine core sites. This result is

594 closely comparable to the average annual sedimentation rate of $0.38 \mathrm{~cm} / \mathrm{yr}$ obtained in this study

595 on marsh sediments deposited between 1961 and 2005 (Table 4).

596 The thicknesses of marsh deposits shown in Table 3 also allow calculation of the relative 
597 contribution of hurricane and non-hurricane sedimentation to growth of the marsh along the

598 transect (Table 5). Hurricane sedimentation, defined as the combined thickness of the storm-

599 surge-deposited sand beds, is greatest at the seaward end of the transect and diminishes inland.

600 At core sites 1-5 the contribution of hurricanes to sedimentation above the base of the Hurricane

601 Rita sand bed is equal to or greater than 85\%. Farther inland, at core sites 6-13, the contribution

602 of hurricanes to sedimentation above the base of the Hurricane Audrey sand bed progressively

603 decreases, reaching $\sim 24 \%$ at core site 13 (Table 5). The contribution of non-hurricane

604 sedimentation, defined as the combined thicknesses of marsh deposits, is the "mirror image" of

605 hurricane contributions, highest at the landward end of the transect at $\sim 76 \%$ and decreasing

606 seaward to only $3.3 \%$ at core site 3 (Table 5).

607 These results are not surprising because they reflect the primary sediment sources for

608 different parts of the transect; at the seaward end of the transect, sedimentation in recent years

609 has been dominated by overwash and the deposition of Hurricane Rita's and Ike's thick storm

610 surge-deposited sand beds. Inland, storm surge-deposited sediment beds become thinner and less

611 important and sedimentation is dominated by marsh deposits formed by sediment deposition

612 from flood waters and greater organic sediment inputs. It should be noted that the contribution of

613 "non-hurricane" sedimentation to marsh growth is likely exaggerated because some of this

614 sedimentation probably resulted from lower-intensity hurricanes that caused flooding and

615 overwash and transported sediment into the marsh, but did not form distinct sediment beds. A

616 significant finding of the study is that, over the last five decades, hurricanes were a predominant

617 or major sediment source for marsh aggradation along the entire transect extending over $1 \mathrm{~km}$

618 inland.

619 The results of this study could be of significant interest for coastal management agencies 
620 along the Northern Gulf of Mexico. This study supports other studies that suggest anthropogenic

621 impacts on inputs of inorganic sediment into sediment-limited marshes could be detrimental to

622 the continued sustainment of coastal marshes subject to sea-level rise (DeLuane et al., 1989;

623 Kennish, 2001; Day et al., 2000). On barrier islands, for example, artificial dunes are constructed

624 that prevent overwash and gradual island migration, until a large storm overtops the artificially

625 high dunes and the barrier morphology adjusts rapidly (Magliocca et al., 2011). Dikes and

626 impoundments also form barriers to inputs of inorganic sediment to marsh surfaces. . This is

627 especially true along the coast of Louisiana. Bryant and Chabreck (1998) investigated the

628 vertical accretion of impounded tidal salt marshes at four sites in the Chenier Plain of

629 southwestern Louisiana. Results of their work indicate that impoundment levees preclude flood

630 delivery of mineral sediment during storms, thereby deminishing accretion of the impounded

631 marshes. Walters and Kirwan (2016) found that 5-15 cm of overwash sedimentation enhances

632 marsh productivity and resilience to sea-level rise. With the exception of the unusually thick

633 washover fans deposited by Hurricane Ike, many of the storm surge deposits documented in this

634 study are within this optimal range (Table 3).

635 Coastal management agencies should consider the results provided in this study, and take

636 into consideration how anthropogenic barriers around coastal marshes could inhibit natural

637 inorganic sedimentation processes. If the highly inorganic marshes in McFaddin National

638 Wildlife Refuge are left in their natural state, without dikes, seawalls, artificial dunes and

639 impoundments; this would allow overwash from future hurricanes to continue depositing

640 inorganic sediment, thereby helping these marshes increase in elevation in order to keep pace

641 with sea-level rise. 


\section{CONCLUSIONS}

644 This study demonstrates the utility of using hurricane storm surge marker beds to assess

645 spatial and temporal patterns in marsh aggradation. This technique, like the use of artificial

646 marker beds in marshes, provides highly accurate sedimentation rates because the exact day of

647 deposition of the marker bed is known. This methodology is applicable in many parts of the

648 world where a better understanding of marsh aggradation dynamics are required to guide coastal

649 management policies aimed at encouraging marsh accretion to combat the effects of sea-level

650 rise. In this study, where marshes are dominated by inorganic sediment, the results show that

651 marsh dynamics are controlled by hurricane activity, flood-derived sedimentation, organic

652 sedimentation, changes in marsh surface elevation and degree of compaction of marsh sediments.

653 Long-term sedimentation rates of marsh deposits formed after Hurricane Carla in 1961 and

654 before Hurricane Rita in 2005 , average $0.38 \mathrm{~cm} / \mathrm{yr}$, which is closely comparable to long-term

655 sedimentation rates in similar marsh settings nearby. Inorganic sediment inputs from Hurricanes

656 Audrey, Carla, Rita and Ike have made major contributions to marsh aggradation in the study

657 area over the last six decades and have helped counteract the effects of sea-level rise on marsh

658 elevation. These results provide improved understanding of the sedimentary response of marshes

659 to tropical cyclone strikes and add support to other studies that encourage coastal management

660 agencies to consider reducing physical barriers to storm surge sedimentation.

\section{ACKNOWLEDGEMENTS}

662 This material is based, in part, upon work supported by the National Science Foundation under

663 Grant No. 0818073. C. Mader assisted with field work. D. Ruffino, C. Crenshaw, P. Walther and

664 B. Dunlap, USFWS McFaddin and Texas Point National Wildlife Refuges, are thanked for 
665 providing access to sites and help with field work. The paper was improved by the comments of 666 two anonymous reviewers.

\section{LITERATURE CITED}

669 Beaudoin A. 2003. A comparison of two methods for estimating the organic matter content of 670 sediments. J. Paleolim. 29: 387-390.

671 Berg, R. 2009. Tropical Cyclone Report Hurricane Ike (AL092008) 1 - 14 September 2008.

672 National Hurricane Center.

673 Berg, R., 2013. Tropical Cyclone Report, Hurricane Isaac (AL092012) 21 August - 1 September

674 2012. National Hurricane Center.

675 Beven, J. 2003. Tropical Cyclone Report Hurricane Claudette 8-17 July 2003. National

676 Hurricane Center.

677 Beven, J.L., Kimberlain, T.B., 2014. Tropical Cyclone Report Hurricane Gustav (AL072008) 25

678 August - 4 September 2008. National Hurricane Center.

679 Blake, E.S., 2007. Tropical Cyclone Report Hurricane Humberto (AL092007) 12-14 September

680 2007. National Hurricane Center.

681 Blum, M.D., Roberts, H.H., 2009. Drowning of the Mississippi Delta due to insufficient

682 sediment supply and global sea-level rise. Nature Geoscience 2, 488-491.

683 Boldt, K.V., Lane, P., Woodruff, J.D., Donnelly, J.P., 2010. Calibrating a sedimentary record of 684 overwash from Southeastern New England using modeled historic hurricane surges. Marine

685 Geology 275, 127-139

686 Brain, M.J., Long, A.J., Woodroffe, S.A., Petley, D.N., Milledge, D.G., Parnell A.C. 2012.

687 Modelling the effects of sediment compaction on salt marsh reconstructions of recent sea-level 
688 rise Earth and Planetary Science Letters, 345-348 (2012), 180-193.

689 Bryant, J.C., Chabreck, R.H., 1998. Effects of impoundment on vertical accretion of coastal

690 marsh. Estuaries, 21, 416-422.

691 Cahoon, D.R., 2006. A review of major storm impacts on coastal wetland elevations. Estuaries 692 and Coasts, 29: 889-898.

693 Case, R.A., Gerrish, H.P., 1983. Atlantic Hurricane Season 1983. National Hurricane Center,

694 National Weather Service, NOAA, Miami, FL.

695 Case, R.A., 1985. Atlantic Hurricane Season 1985. National Hurricane Center, National Weather

696 Service, NOAA, Miami, FL.

697 Case, B., Mayfield, M., 1990. Atlantic Hurricane Season of 1989. National Hurricane Center,

698 National Weather Service, NOAA, Miami, FL.

699 Cherry, J.A., McKee, K.L., Grace, J.B., 2008. Elevated CO2 enhances biological contributions to

700 elevation change in coastal wetlands by offsetting stressors associated with sea-level rise. Journal

701 of Ecology. 97: 67-77.

702 Crosby, M.K., Reese, C.A., 2009. Geologic Evidence of Hurricane Rita Recovered from Texas

703 Point, TX. Southeastern Geographer 49, 41-48.

704 Day, J.W., Britsch, L.D., Hawes, S.R., Shaffer, G.P., Reed, D.J., Cahoon, D., 2000. Pattern and 705 process of land loss in the Mississippi Delta: a spatial and temporal analysis of wetland habitat 706 change. Estuaries, 23(4), 425-438.

707 Dean W.E. 1974. Determination of carbonate and organic matter in calcareous sediments and 708 sedimentary rocks by loss on ignition: comparison with other methods. J. Sed. Petrol. 44: 242709248.

710 Deegan, L.A., Kennedy, H.M., Neill, C., 1984. Natural factors and human modifications 
711 contributing to marsh loss in Louisiana's Mississippi River Delta Plain. Environmental

712 Management, 8, 519-528.

713 DeLaune, R.D., Nyman, J.A., Patrick, W.H. Jr, 1994. Peat collapse, ponding and wetland loss in

714 a rapidly submerging coastal marsh. J. Coastal Res., 10, 1021-1030.

715 DeLaune, R.D., Jugsujinda, A., Peterson, G., Patrick, W., 2003. Impact of Mississippi River

716 freshwater reintroduction on enhancing marsh accretionary processes in a Louisiana estuary.

717 Estuarine Coast. Shelf Sci., 58, 653-662.

718 Deluane, R.D., Whitcomb, J.H., Patrick, JR., W.H., Pardue, H.H., Pezeshki,S.R., 1989.

719 Accretion and canal impacts in a rapidly subsiding wetland: $137 \mathrm{Cs}$ and $210 \mathrm{~Pb}$ techniques.

720 Estuaries, 12, 247- 259.

721 Dunn, G.E., Moore, P.L., Clark, G.B., Frank, N.L., Hill, E.C., Kraft, R., Sugg, A., 1964. The 722 Hurricane Season of 1964. U.S. Weather Bureau Office, Miami, FL.

723 Franklin, J.L., 2008. Tropical Cyclone Report, Tropical Storm Edouard (AL052008), 3-6 August 724 2008. National Hurricane Center.

725 Freeman, A.M., Jose, F., Roberts, H.H., Stone, G.W., 2015. Storm induced hydrodynamics and 726 sediment transport in a coastal Louisiana lake. Est. Coast. Shelf Sci., 161, 65-75.

727 Garmin, 2007. Garmin Etrek HC Owner's Manual.

728 Gedan, K.B., Kirwan, M.L., Wolanski, E., Barbier, E.B., Silliman, B.R., 2011. The present and 729 future role of coastal wetland vegetation in protecting shorelines: answering recent challenges to 730 the paradigm. Climatic Change, 106(1), 7-29.

731 Glick, P., Clough, J., Polaczyk, A., Couvillion, B., Nunley, B., 2013. Potential Effects of Sea732 Level Rise on Coastal Wetlands in Southeastern Louisiana. Journal of Coastal Research, Special 733 Issue 63, 211-233. 
734 Gustafson, P.F., 1969. 137-Cs in the U.S. diet 1961-69 and the influence of climatic and

735 agricultural factors: Proceedings of the Symposium on Environmental Contamination by

736 Radioactive Materials, United Nations, Vienna, 1969: 135-143.

737 Heiri O., Lotter A.F., Lemcke G., 2001. Loss on ignition as a method for estimating organic and 738 carbonate content in sediments: reproducibility and comparability of results. J. Paleolim. 25:

$739 \quad 101-110$.

740 Hill, T.D., Anisfeld, S.C., 2015. Coastal wetland response to sea level rise in Connecticut and

741 New York. Estuar. Coast. Shelf Sci. 163, 185-193.

742 Ho, F.P., Miller, J.F., 1982. NOAA Technical Report NWS 32. Pertinent Meteorological and

743 Hurricane Tide Data for Hurricane Carla. Silver Spring, Md.

744 Kennish, M.J., 2001. Coastal salt marsh systems in the U.S.: A review of anthropogenic impacts.

745 Journal of Coastal Research, 17, 731-748.

746 Kent, J.D. Dokka, R.K., 2013. Potential impacts of long-term subsidence on the wetlands and

747 evacuation routes in coastal Louisiana. GeoJournal 78, 641-655.

748 Knabb, R.D., Brown, D.P., Rhome, J.R., 2006. Tropical Cyclone Report Hurricane Rita 18 - 26

749 September 2005 National Hurricane Center.

750 Landreneau, D., Shamburger, S., 2009. Hurricane Audrey. National Weather Service Weather

751 Forecast Office, Lake Charles, LA.

752 Lawrence, M.B. 1987. Atlantic Hurricane Season of 1986. Monthly Weather Review, 115, $753 \quad 2155-2160$.

754 Lawrence, M.B., 2002. Tropical Cyclone Report Hurricane Lili 21 September - 04 October 2002.

755 National Hurricane Center.

756 Liu, K-b., 2004. Paleotempestology: Principles, methods, and examples from Gulf Coast lake 
757 sediments in hurricanes and typhoons: Past, present, and future. Ed. R.J. Murnane and K-b. Liu, 758 Columbia University Press, 464 pages.

759 Liu, K.., McCloskey, T.A., Bianchette, T.A., Keller, G., Lam, N.S.N., Cable, J.E., Arriola, J., 760 2014. Hurricane Isaac Storm Surge Deposition in a Coastal Wetland along Lake Pontchartrain, 761 Southern Louisiana. In: Green, A.N. and Cooper, J.A.G. (eds.), Proceedings 13th International 762 Coastal Symposium (Durban, South Africa), Journal of Coastal Research, Special Issue No. 70, $763 \quad 266-271$.

764 Magliocca, N.R., McNamara, D.E., Murray, A.B., 2011. Long-term, large-scale morphodynamic 765 effects of artificial dune construction along a barrier island coastline. Journal of Coastal 766 Research, 27(5), 918-930.

767 McKee, K.L., Cherry, J.A. 2009. Hurricane Katrina sediment slowed elevation loss in subsiding 768 brackish marshes of the Mississippi River Delta. Wetlands 29: 2-15.

769 Milan, C.S., Swenson, E.M., Turner, R.E., Lee, J.M., 1995. Assessmnet of the 137Cs method for 770 estimating sediment accumulation rates: Louisiana salt marshes. Journal of Coastal Research, 11, $771 \quad 296-307$.

772 Mitsch, W.J., Gosselink, J.G., 1984. Wetlands. Van Nostrand Reinhold, New York, 539 pp.

773 Moore, P., 1957. The Hurricane Season of 1957. Monthly Weather Review, 401- 408, Miami, 774 Florida.

775 Naquin, J.D., Liu, K.B., McCloskey, T.A., Bianchette, T.A., 2014. Storm Deposition Induced by 776 Hurricanes in a Subsiding Coastal Zone. In: Green, A.N. and Cooper, J.A.G. (eds.), Proceedings 777 13th International Coastal Symposium (Durban, South Africa), Journal of Coastal Research, 778 Special Issue No. 70, 308-313.

779 National Hurricane Center, 1983. Hurricane Alicia Preliminary Report. Miami, Florida. 
780 National Weather Service, 2011. Remembering Carla: $50^{\text {th }}$ Anniversary. National Weather

781 Service Weather Forecast Office Corpus Christi, Texas.

782 http://www.srh.noaa.gov/crp/?n=hurricanecarla

783 National Weather Service, 2016. Upper Texas Coast Tropical Cyclones in the 1980s. Weather

784 Forecast Office Houston/Galveston, TX.

785 http://www.srh.noaa.gov/hgx/?n=hurricanes_climatology_1980s

786 Nyman, J.A., Crozier, C.R., DeLaune, R.D., 1995. Roles and patterns of hurricane sedimentation

787 in an estuarine marsh landscape. Estuarine, Coastal and Shelf Science, 40, 665-679.

788 Rappaport, E., 1993. Hurricane Andrew 16-28 August, 1992, Preliminary Report. National

789 Hurricane Center.

790 Roberts, H.H., DeLaune, R.D., White, J.R., Li, C., Sasser, C.E., Braud, D., Weeks, E., Khalid,

791 S., 2015. Floods and Cold Front Passages: Impacts on Coastal Marshes in a River Diversion

792 Setting (Wax Lake Delta, Louisiana). Journal of Coastal Research, 31: 1057-1068.

793 Santisteban, J. I., Mediavilla, R., López-Pamo, Dabrio, C.J., Ruiz-Zapata, M.B., Gil García, M.J.,

794 Castaño, S., Martínez-Alfaro, P.E., 2004. Loss on ignition: a qualitative or quantitative method

795 for organic matter and carbonate mineral content in sediments? Journal of Paleolimnology 32:

$796 \quad 287-299$.

797 Sasser, C.E., Dozier, M.D., Gosselink,J.G., Hill, J.M., 1986. Spatial and temporal changes in 798 Louisiana's Barataria Basin marshes, 1945-1980. Environmental Management, 10, 671-680.

799 Simpson, R.H., Hope, J.R., 1971. Atlantic Hurricane Season of 1971. National Hurricane Center, 800 National Weather Service, NOAA, Miami, FL.

801 Stone, G.W., Grymes, J.M., III, Dingler, J.R., Pepper, D.A., 1997. Overview and significance of 802 hurricanes on the Louisiana coast, USA. Journal of Coastal Research, 13, 656-669. 
803 Swenson, E.M., Turner, R.E., 1987. Spoil banks: effects on a coastal marsh water level regime.

804 Estuarine and Continental Shelf Science, 24, 599-609.

805 Törnqvist, T.E., Paola, C., Parker, G., Liu, K-b, Mohrig, D., Holbrook, J.M., Twilley, R.R.,

806 2006. Comment on "Wetland Sedimentation from Hurricanes Katrina and Rita." Science, 201b.

807 Turner, R.E., 1990. Landscape development and coastal wetland losses in the northern Gulf of

808 Mexico. American Zoologist, 30, 89- 105.

809 Turner, R.E., 1997. Wetland Loss in the Northern Gulf of Mexico: Multiple Working

810 Hypotheses. Estuaries, 20, 1-13.

811 Turner, R.E., Baustian, J.J., Swenson, E.M., Spicer, J.S., 2006. Wetland sedimentation from

812 Hurricanes Katrina and Rita. Science, 449-452.

813 Tweel, A.W., Turner, R.E., 2012. Landscape-scale analysis of wetland sediment deposition from

814 four tropical cyclone events. PLoS One 7, e50528.

815 Tweel, A.W., Turner, R.E., 2014. Contribution of tropical cyclones to the sediment budget for

816 coastal wetlands in Louisiana, USA. Landscape Ecology 29, 1083-1094.

817 U.S. Fish and Wildlife Service. 2016. National Wetlands Inventory Mapper.

818 http://www.fws.gov/wetlands/Data/Mapper.html

819 U.S. Weather Bureau, 1959. Hurricane Debra, July 24-26, 1959. Preliminary report with

820 advisories and bulletins issued.

821 U.S. Weather Bureau, 1961. Hurricane Carla, September 6-14, 1961. Preliminary report with

822 advisories and bulletins issued.

823 U.S. Weather Bureau, 1963. Hurricane Cindy, September 16-18, 1963. Preliminary report with 824 advisories and bulletins issued.

825 Walters, D.C., Kirwan, M.L., 2016. Optimal hurricane overwash thickness for maximizing marsh 
826 resilience to sea level rise. Ecology and Evolution 6: 2948-2956.

827 White, W.A., Morton, R.A., 1997. Wetland losses related to fault movement and hydrocarbon

828 production, southeastern Texas Coast. Journal of Coastal Research, 13, 1305-1320.

829 Williams, H.F.L., 1995. Assessing the impact of weir construction on recent sedimentation using

830 Cesium-137. Environmental Geology, 26: 166-171.

831 Williams, H.F.L., 2003. Modeling shallow autocompaction in coastal marshes using Cesium-

832137 fallout: Preliminary results from the Trinity River Estuary, Texas. Journal of Coastal

833 Research, 19, 180-188.

834 Williams, H.F.L., 2010. Storm surge deposition by Hurricane Ike on the McFaddin National

835 Wildlife Refuge, Texas: Implications for paleotempestology studies. Journal of Foraminiferal

836 Research, 40, 510-519.

837 Williams, H.F.L., 2011. Stratigraphic record of Hurricanes Audrey, Rita and Ike in the Chenier

838 Plain of Southwest Louisiana. Journal of Coastal Research, Special Issue 64, 1921-1926.

839 Williams, H.F.L., 2012. Magnitude of Hurricane Ike storm surge sedimentation: Implications for

840 coastal marsh aggradation. Earth Surface Processes and Landforms, 37, 901-906.

841 Williams, H.F.L., Flanagan, W.M., 2009. Contribution of Hurricane Rita storm surge deposition

842 to long-term sedimentation in Louisiana coastal woodlands and marshes. Journal of Coastal

843 Research, Special Issue 56, 1671-1675.

844 Williams, H.F.L., Denlinger, E., 2013. Contribution of Hurricane Ike storm surge sedimentation

845 to long-term aggradation of Southeastern Texas coastal marshes. Journal of Coastal Research,

846 Special Issue 65, 838-843.

847 Yuill, B., Lavoie, D., Reed, D.J., 2009. Understanding subsidence processes in coastal Louisiana.

848 Journal of Coastal Research, Special Issue 54, 23-36. 
Table 1

Foraminiferal content of selected samples from core 4.

\begin{tabular}{|c|c|c|c|c|c|c|c|c|c|c|c|c|c|c|c|c|c|}
\hline Depth (cm) & $29-30$ & $30-31$ & $31-32$ & $33-34$ & $34-35$ & $35-36$ & $37-38$ & $38-39$ & $39-40$ & $40-41$ & $41-42$ & $43-44$ & $45-46$ & $47-48$ & $49-50$ & $52-53$ & $55-56$ \\
\hline Sample Weight (g) & 1.340 & 1.755 & 1.244 & 1.186 & 1.389 & 1.377 & 1.217 & 0.890 & 1.782 & 1.073 & 0.989 & 1.556 & 1.552 & 1.865 & 0.530 & 0.665 & 0.786 \\
\hline Weight Counted (g) & 0.274 & 0.147 & 0.188 & 0.215 & 0.183 & 0.213 & 0.086 & 0.122 & 0.117 & 0.110 & 0.076 & 0.111 & 1.552 & 0.152 & 0.530 & 0.223 & 0.211 \\
\hline Ammonia sp. & 35 & 30 & 52 & 1 & 0 & 0 & 5 & 5 & 3 & 6 & 1 & 2 & 1 & 26 & 0 & 0 & 0 \\
\hline Elphidium sp. & 28 & 30 & 37 & 5 & 1 & 0 & 1 & 11 & 6 & 20 & 11 & 6 & 0 & 19 & 1 & 0 & 0 \\
\hline Haynesina sp & 0 & 0 & 3 & 0 & 0 & 0 & 0 & 0 & 0 & 0 & 0 & 0 & 0 & 0 & 0 & 0 & 0 \\
\hline Quinqueloculina sp & 3 & 4 & 10 & 0 & 0 & 0 & 0 & 0 & 0 & 0 & 0 & 0 & 0 & 0 & 0 & 0 & 0 \\
\hline Ammobaculites sp. & 0 & 0 & 0 & 0 & 0 & 0 & 0 & 0 & 0 & 0 & 0 & 0 & 0 & 0 & 0 & 0 & 0 \\
\hline Haplophragmoides sp. & 0 & 0 & 0 & 9 & 3 & 0 & 1 & 0 & 0 & 1 & 0 & 0 & 0 & 0 & 0 & 0 & 0 \\
\hline Miliammina fusca & 0 & 0 & 0 & 0 & 0 & 0 & 0 & 0 & 0 & 0 & 0 & 0 & 0 & 0 & 0 & 0 & 0 \\
\hline Jadammina macrescens & 0 & 0 & 0 & 10 & 11 & 7 & 1 & 0 & 1 & 1 & 0 & 0 & 0 & 0 & 0 & 0 & 0 \\
\hline Trochammina inflata & 0 & 0 & 0 & 9 & 10 & 10 & 0 & 0 & 0 & 0 & 0 & 0 & 0 & 0 & 0 & 0 & 0 \\
\hline total counted & 66 & 64 & 102 & 34 & 25 & 17 & 8 & 16 & 10 & 28 & 12 & 8 & 1 & 45 & 1 & 0 & 0 \\
\hline calcareous \% & 100 & 100 & 100 & 18 & 4 & 0 & 75 & 100 & 90 & 93 & 100 & 100 & 100 & 100 & 100 & 0 & 0 \\
\hline agglutinated $\%$ & 0 & 0 & 0 & 82 & 96 & 100 & 25 & 0 & 10 & 7 & 0 & 0 & 0 & 0 & 0 & 0 & 0 \\
\hline Number in sample & 323 & 764 & 675 & 188 & 190 & 110 & 113 & 117 & 152 & 273 & 156 & 112 & 1 & 552 & 1 & 0 & 0 \\
\hline Number per gram & 241 & 435 & 543 & 158 & 137 & 80 & 93 & 131 & 85 & 255 & 158 & 72 & 1 & 296 & 2 & 0 & 0 \\
\hline
\end{tabular}


Table 2.

Storm tides and maximum sustained winds in the vicinity of the study area resulting from hurricanes passing within $300 \mathrm{~km}, 1950-2014$ (in descending order of storm tide height).

\begin{tabular}{|c|c|c|c|c|c|}
\hline \multirow[t]{2}{*}{ Year } & \multirow[t]{2}{*}{ Name } & \multirow{2}{*}{$\begin{array}{l}\text { Category } \\
\text { at } \\
\text { landfall }\end{array}$} & \multirow{2}{*}{$\begin{array}{l}\text { Landfall proximity } \\
\text { to study area }(\mathrm{km}) \\
\text { (East or West) }\end{array}$} & \multicolumn{2}{|c|}{ Conditions in vicinity of study area ${ }^{1}$} \\
\hline & & & & $\begin{array}{l}\text { Storm tide }^{2}(\mathrm{~m}) \\
\text { (location) }\end{array}$ & $\begin{array}{l}\text { Maximum sustained } \\
\text { winds (kts) (location) }\end{array}$ \\
\hline 2008 & Ike & 2 & $75(\mathrm{~W})$ & $4.31(\mathrm{SP})^{\mathrm{a}}$ & $65(\mathrm{SP})^{\mathrm{a}}$ \\
\hline 2005 & Rita & 3 & $33(\mathrm{E})$ & $2.81(\mathrm{PA})^{\mathrm{b}}$ & $61(\mathrm{PA})^{\mathrm{b}}$ \\
\hline 1957 & Audrey & 4 & $35(\mathrm{E})$ & $2.79(\mathrm{SP})^{\mathrm{c}}$ & $74(\mathrm{SP})^{\mathrm{d}}$ \\
\hline 1961 & Carla & 4 & $290(\mathrm{~W})$ & $2.25(\mathrm{SP})^{\mathrm{e}}$ & $76(G)^{f}$ \\
\hline 1986 & Bonnie & 1 & $26(\mathrm{~W})$ & $1.64(\mathrm{SP})^{\mathrm{g}}$ & $54(\mathrm{PA})^{\mathrm{h}}$ \\
\hline 2002 & Lili & 1 & $173(\mathrm{E})$ & $1.64(\mathrm{BAP})^{\mathrm{i}}$ & $27(\mathrm{BAP})^{\mathrm{i}}$ \\
\hline 1983 & Alicia & 3 & $117(\mathrm{~W})$ & $1.59(\mathrm{HI})^{\mathrm{j}}$ & $35(\mathrm{PA})^{\mathrm{k}}$ \\
\hline 2007 & Humberto & 1 & $35(\mathrm{~W})$ & $1.47{\text { (TPNWR })^{1}}^{1}$ & $52(\mathrm{MNWR})^{1}$ \\
\hline 1971 & Edith & 2 & $123(\mathrm{E})$ & $1.21(\mathrm{SP})^{\mathrm{m}}$ & $30(\mathrm{SP})^{\mathrm{m}}$ \\
\hline 1989 & Chantal & 1 & $36(\mathrm{~W})$ & $1.19(\mathrm{SRSP})^{\mathrm{n}}$ & $47(\mathrm{HI})^{\mathrm{n}}$ \\
\hline 1963 & Cindy & 1 & $37(\mathrm{~W})$ & $1.15(\mathrm{SP})^{\mathrm{o}}$ & $36(\mathrm{PA})^{\circ}$ \\
\hline 2003 & Claudette & 1 & $272(\mathrm{~W})$ & $1.01(\mathrm{RP})^{\mathrm{p}}$ & $45{(\text { SRSP })^{\mathrm{p}}}^{-}$ \\
\hline 2008 & Gustav & 2 & $322(\mathrm{E})$ & $0.85(\mathrm{SP})^{\mathrm{q}}$ & $32(\mathrm{SP})^{\mathrm{q}}$ \\
\hline 1964 & Hilda & 2 & $240(\mathrm{E})$ & $0.78(\mathrm{SP})^{\mathrm{r}}$ & $30(\mathrm{SP})^{\mathrm{r}}$ \\
\hline 1989 & Jerry & 1 & $102(\mathrm{~W})$ & $0.69(\mathrm{SP})^{\mathrm{s}}$ & $41(\mathrm{GWSO})^{\mathrm{s}}$ \\
\hline 1959 & Debra & 1 & $115(\mathrm{~W})$ & $0.48(\mathrm{HI})^{\mathrm{t}}$ & $39(\mathrm{HI})^{\mathrm{t}}$ \\
\hline 1992 & Andrew & 3 & $262(\mathrm{E})$ & $0.39(\mathrm{SP})^{\mathrm{u}}$ & $22(\mathrm{PA})^{\mathrm{u}}$ \\
\hline 1985 & Juan & 1 & $245(\mathrm{E})$ & $1.1^{*}(\mathrm{SP})^{\mathrm{v}}$ & $27(\mathrm{PA})^{\mathrm{v}}$ \\
\hline 1985 & Danny & 1 & $130(\mathrm{E})$ & $0.9^{*}(\mathrm{SP})^{\mathrm{v}}$ & $19(\mathrm{PA})^{\mathrm{v}}$ \\
\hline 2012 & Isaac & 1 & $330(\mathrm{E})$ & N/A & $30(\mathrm{SP})^{\mathrm{w}}$ \\
\hline 1974 & Carmen & 3 & $275(\mathrm{E})$ & N/A & $\mathrm{N} / \mathrm{A}$ \\
\hline 1965 & Betsy & 3 & $330(\mathrm{E})$ & N/A & N/A \\
\hline 1977 & Babe & 1 & $267(\mathrm{E})$ & N/A & N/A \\
\hline
\end{tabular}

Tide and wind record locations were selected for close proximity to MNWR study area.

${ }^{2}$ Storm tide is normal tide plus storm surge (NAVD88).

Location key: SP: Sabine Pass, G: Galveston, PA: Port Arthur, BAP: Beaumont Air Port, HI:

High Island, TPNWR: Texas Point National Wildlife Refuge, MNWR: McFaddin National

Wildlife Refuge, SRSP: Sea Rim State Park, RP: Rollover Pass.

* Height above normal tide

N/A: significant hurricane-related conditions not recorded in vicinity of study area.

Wind and tide data sources: ${ }^{\mathrm{a}}$ Berg, 2009;; ${ }^{\mathrm{b}}$ Knabb et al., 2006; ${ }^{\mathrm{c}}$ Moore et al., 1957;

${ }^{\mathrm{d}}$ Landreneau and Shamburger, 2009; ${ }^{\mathrm{e}}$ Ho and Miller, 1982; ${ }^{\mathrm{f}}$ U.S. Weather Bureau, 1961;

${ }^{\mathrm{g}}$ National Weather Service, 2016; ${ }^{\mathrm{h}}$ Lawrence, 1987; ${ }^{\mathrm{i}}$ Lawrence, 2002; ${ }^{\mathrm{j}}$ Case and Gerrish, 1983;

${ }^{\mathrm{k}}$ National Hurricane Center, 1983; ${ }^{1}$ Blake, 2007; ${ }^{\mathrm{m}}$ Simpson and Hope, 1971; ${ }^{\mathrm{n}}$ Case and

Mayfield, 1990; ${ }^{\circ}$ U.S. Weather Bureau, 1963; ${ }^{\mathrm{p}}$ Beven, 2003; ${ }^{\mathrm{q}}$ Beven and Kimberlain, 2014;

${ }^{\mathrm{r}}$ Dunn et al., 1964; ${ }^{\mathrm{s}}$ Case and Mayfield, 1990; ${ }^{\mathrm{t}}$ U.S. Weather Bureau, 1959; ${ }^{\mathrm{u}}$ Rappaport, 1993;

${ }^{\mathrm{v}}$ Case, 1985; ${ }^{\mathrm{w}}$ Berg, 2013.

Table 3. 
Marsh and hurricane deposit thicknesses ${ }^{1}(\mathrm{~cm}): 1957-2014$.

\begin{tabular}{|c|c|c|c|c|c|c|c|c|c|}
\hline Core & $\begin{array}{l}\text { Marsh: } \\
2008- \\
2014\end{array}$ & $\begin{array}{l}\text { Hurricane } \\
\text { Ike } \\
\text { Deposit }\end{array}$ & $\begin{array}{l}\text { Marsh: } \\
\text { 2005- } \\
2008\end{array}$ & $\begin{array}{l}\text { Hurricane } \\
\text { Rita } \\
\text { Deposit }\end{array}$ & $\begin{array}{l}\text { Marsh: } \\
1961- \\
2005\end{array}$ & $\begin{array}{l}\text { Hurricane } \\
\text { Carla } \\
\text { Deposit }\end{array}$ & $\begin{array}{l}\text { Marsh: } \\
1957- \\
1961\end{array}$ & $\begin{array}{l}\text { Hurricane } \\
\text { Audrey } \\
\text { Deposit }\end{array}$ & $\begin{array}{l}\text { Carla and } \\
\text { Audrey } \\
\text { Combined }^{2}\end{array}$ \\
\hline 1 & 0 & 37.8 & 3.5 & 15.3 & - & - & - & - & - \\
\hline 2 & 0 & 48.7 & 5.8 & 18.6 & - & - & - & - & - \\
\hline 3 & 0 & 56.4 & 2.3 & 11.5 & - & - & - & - & - \\
\hline 4 & 0 & 40.0 & 8.8 & 12.5 & - & - & - & - & - \\
\hline 5 & 0 & 22.5 & 6.4 & 13.9 & - & - & - & - & - \\
\hline T5-5 & 0 & 24.6 & 7.5 & 10.7 & 18.2 & 3.7 & 0.5 & 1.6 & - \\
\hline 6 & 0 & 14.3 & 4.1 & 8.2 & 16.3 & 2.0 & 0.5 & 2.6 & - \\
\hline 7 & 1.0 & 9.2 & 7.1 & 4.1 & 19.4 & - & - & - & 5.1 \\
\hline 8 & 0 & 12.5 & - & - & - & 2.1 & 1.0 & 5.2 & - \\
\hline 9 & 2.2 & 9.7 & 5.4 & 5.4 & 15.1 & 2.2 & 0.5 & 0.5 & - \\
\hline 10 & 2.2 & 4.5 & 7.8 & 4.5 & 11.2 & - & - & - & 4.5 \\
\hline 11 & 0 & 5.9 & - & - & - & - & - & - & - \\
\hline 12 & 2.1 & 3.2 & - & - & - & - & - & - & - \\
\hline 13 & 2.2 & 2.2 & 11.9 & 3.2 & 19.4 & - & - & - & 5.4 \\
\hline
\end{tabular}

${ }^{1}$ adjusted to remove compaction, which presumably introduced small uncertainties in estimated thicknesses; ${ }^{2}$ hurricane deposits apparently combined by bioturbation.

Table 4.

Marsh average annual sedimentation rates $(\mathrm{cm} /$ year)

\begin{tabular}{ccccc}
\hline Core & $2008-2014^{1}$ & $2005-2008^{2}$ & $1961-2005^{3}$ & $1957-1961^{4}$ \\
\hline 1 & 0.00 & 1.19 & - & - \\
2 & 0.00 & 1.95 & - & - \\
3 & 0.00 & 0.77 & - & - \\
4 & 0.00 & 2.95 & - & - \\
5 & 0.00 & 2.16 & - & - \\
T5-5 & 0.00 & 2.52 & 0.41 & 0.13 \\
6 & 0.00 & 1.37 & 0.37 & 0.12 \\
7 & 0.17 & 2.40 & 0.44 & - \\
8 & 0.00 & - & - & 0.25 \\
9 & 0.36 & 1.82 & 0.34 & 0.13 \\
10 & 0.38 & 2.64 & 0.25 & - \\
11 & 0.00 & - & - & - \\
12 & 0.35 & - & - & - \\
13 & 0.36 & 3.64 & 0.44 & - \\
Average & 0.12 & 2.13 & 0.38 & 0.16 \\
\hline 15.92 years; ${ }^{2} 2.97$ years; ${ }^{3} 44.04$ years; ${ }^{4} 4.21$ years
\end{tabular}


Table 5.

Hurricane and non-hurricane sedimentation ${ }^{1}$

\begin{tabular}{rcccccc} 
Core $^{2}$ & $\begin{array}{l}\text { Depth to Base of } \\
\text { Hurricane Audrey } \\
\text { Deposit }(\mathrm{cm})^{3}\end{array}$ & $\begin{array}{l}\text { Depth to Base of } \\
\text { Hurricane Rita } \\
\text { Deposit }(\mathrm{cm})^{4}\end{array}$ & $\begin{array}{l}\text { Hurricane } \\
\text { Sedimentation } \\
(\mathrm{cm})^{5}\end{array}$ & $\begin{array}{l}\text { Non-Hurricane } \\
\text { Sedimentation } \\
(\mathrm{cm})^{6}\end{array}$ & $\begin{array}{l}\text { \% Hurricane } \\
\text { Sedimentation }\end{array}$ & $\begin{array}{l}\text { \% Non-Hurricane } \\
\text { Sedimentation }\end{array}$ \\
\hline 1 & - & 56.6 & 53.1 & 3.5 & 93.8 & 6.3 \\
2 & - & 73.1 & 67.3 & 5.8 & 92.1 & 7.9 \\
3 & - & 70.2 & 67.9 & 2.3 & 96.7 & 3.3 \\
4 & - & 61.3 & 52.5 & 8.8 & 85.7 & 14.3 \\
5 & - & 42.8 & 36.4 & 6.4 & 85.0 & 15.0 \\
$\mathrm{~T} 5-5$ & 66.9 & 42.8 & 40.7 & 26.2 & 60.8 & 39.2 \\
6 & 47.9 & 26.5 & 27.0 & 20.9 & 56.4 & 43.6 \\
7 & 45.9 & 21.4 & 18.4 & 27.5 & 40.0 & 60.0 \\
8 & 44.7 & - & 19.7 & 25.0 & 44.2 & 55.8 \\
9 & 41.0 & 22.7 & 17.8 & 23.2 & 43.4 & 56.6 \\
10 & 34.7 & 19.0 & 13.4 & 21.3 & 38.7 & 61.3 \\
13 & 44.3 & 19.4 & 10.8 & 33.5 & 24.4 & 75.6 \\
\hline
\end{tabular}

${ }^{1}$ adjusted to remove compaction; ${ }^{2}$ cores 11 and 12 did not contain Hurricane Audrey's or Rita's deposit and are excluded; ${ }^{3}$ used to find hurricane/non-hurricane sedimentation in cores T5-5 10 and core $13 ;{ }^{4}$ used to find hurricane/non-hurricane sedimentation in cores $1-5 ;{ }^{5}$ combined thickness of hurricane sand beds; ${ }^{6}$ combined thickness of marsh deposits. 
Table 1.

Foraminiferal content of selected samples from core 4.

\begin{tabular}{|c|c|c|c|c|c|c|c|c|c|c|c|c|c|c|c|c|c|}
\hline Depth (cm) & $29-30$ & $30-31$ & $31-32$ & $33-34$ & $34-35$ & $35-36$ & $37-38$ & $38-39$ & $39-40$ & $40-41$ & $41-42$ & $43-44$ & $45-46$ & $47-48$ & $49-50$ & $52-53$ & $55-56$ \\
\hline$\overline{\text { Sample Weight (g) }}$ & 1.340 & 1.755 & 1.244 & 1.186 & 1.389 & 1.377 & 1.217 & 0.890 & 1.782 & 1.073 & 0.989 & 1.556 & 1.552 & 1.865 & 0.530 & 0.665 & 0.786 \\
\hline Weight Counted (g) & 0.274 & 0.147 & 0.188 & 0.215 & 0.183 & 0.213 & 0.086 & 0.122 & 0.117 & 0.110 & 0.076 & 0.111 & 1.552 & 0.152 & 0.530 & 0.223 & 0.211 \\
\hline Ammonia sp. & 35 & 30 & 52 & 1 & 0 & 0 & 5 & 5 & 3 & 6 & 1 & 2 & 1 & 26 & 0 & 0 & 0 \\
\hline Elphidium sp. & 28 & 30 & 37 & 5 & 1 & 0 & 1 & 11 & 6 & 20 & 11 & 6 & 0 & 19 & 1 & 0 & 0 \\
\hline Haynesina sp & 0 & 0 & 3 & 0 & 0 & 0 & 0 & 0 & 0 & 0 & 0 & 0 & 0 & 0 & 0 & 0 & 0 \\
\hline Quinqueloculina sp & 3 & 4 & 10 & 0 & 0 & 0 & 0 & 0 & 0 & 0 & 0 & 0 & 0 & 0 & 0 & 0 & 0 \\
\hline Ammobaculites sp. & 0 & 0 & 0 & 0 & 0 & 0 & 0 & 0 & 0 & 0 & 0 & 0 & 0 & 0 & 0 & 0 & 0 \\
\hline Haplophragmoides sp. & 0 & 0 & 0 & 9 & 3 & 0 & 1 & 0 & 0 & 1 & 0 & 0 & 0 & 0 & 0 & 0 & 0 \\
\hline Miliammina fusca & 0 & 0 & 0 & 0 & 0 & 0 & 0 & 0 & 0 & 0 & 0 & 0 & 0 & 0 & 0 & 0 & 0 \\
\hline Jadammina macrescens & 0 & 0 & 0 & 10 & 11 & 7 & 1 & 0 & 1 & 1 & 0 & 0 & 0 & 0 & 0 & 0 & 0 \\
\hline Trochammina inflata & 0 & 0 & 0 & 9 & 10 & 10 & 0 & 0 & 0 & 0 & 0 & 0 & 0 & 0 & 0 & 0 & 0 \\
\hline total counted & 66 & 64 & 102 & 34 & 25 & 17 & 8 & 16 & 10 & 28 & 12 & 8 & 1 & 45 & 1 & 0 & 0 \\
\hline calcareous \% & 100 & 100 & 100 & 18 & 4 & 0 & 75 & 100 & 90 & 93 & 100 & 100 & 100 & 100 & 100 & 0 & 0 \\
\hline agglutinated $\%$ & 0 & 0 & 0 & 82 & 96 & 100 & 25 & 0 & 10 & 7 & 0 & 0 & 0 & 0 & 0 & 0 & 0 \\
\hline Number in sample & 323 & 764 & 675 & 188 & 190 & 110 & 113 & 117 & 152 & 273 & 156 & 112 & 1 & 552 & 1 & 0 & 0 \\
\hline Number per gram & 241 & 435 & 543 & 158 & 137 & 80 & 93 & 131 & 85 & 255 & 158 & 72 & 1 & 296 & 2 & 0 & 0 \\
\hline
\end{tabular}


Table 2.

Storm tides and maximum sustained winds in the vicinity of the study area resulting from hurricanes passing within $300 \mathrm{~km}, 1950-2014$ (in descending order of storm tide height).

\begin{tabular}{|c|c|c|c|c|c|}
\hline \multirow[t]{2}{*}{ Year } & \multirow[t]{2}{*}{ Name } & \multirow{2}{*}{$\begin{array}{l}\text { Category } \\
\text { at } \\
\text { landfall }\end{array}$} & \multirow{2}{*}{$\begin{array}{l}\text { Landfall proximity } \\
\text { to study area }(\mathrm{km}) \\
\text { (East or West) }\end{array}$} & \multicolumn{2}{|c|}{ Conditions in vicinity of study area ${ }^{1}$} \\
\hline & & & & $\begin{array}{l}\text { Storm tide }^{2}(\mathrm{~m}) \\
\text { (location) }\end{array}$ & $\begin{array}{l}\text { Maximum sustained } \\
\text { winds (kts) (location) }\end{array}$ \\
\hline 2008 & Ike & 2 & $75(\mathrm{~W})$ & $4.31(\mathrm{SP})^{\mathrm{a}}$ & $65(\mathrm{SP})^{\mathrm{a}}$ \\
\hline 2005 & Rita & 3 & $33(\mathrm{E})$ & $2.81(\mathrm{PA})^{\mathrm{b}}$ & $61(\mathrm{PA})^{\mathrm{b}}$ \\
\hline 1957 & Audrey & 4 & $35(\mathrm{E})$ & $2.79(\mathrm{SP})^{\mathrm{c}}$ & $74(\mathrm{SP})^{\mathrm{d}}$ \\
\hline 1961 & Carla & 4 & $290(\mathrm{~W})$ & $2.25(\mathrm{SP})^{\mathrm{e}}$ & $76(G)^{f}$ \\
\hline 1986 & Bonnie & 1 & $26(\mathrm{~W})$ & $1.64(\mathrm{SP})^{\mathrm{g}}$ & $54(\mathrm{PA})^{\mathrm{h}}$ \\
\hline 2002 & Lili & 1 & $173(\mathrm{E})$ & $1.64(\mathrm{BAP})^{\mathrm{i}}$ & $27(\mathrm{BAP})^{\mathrm{i}}$ \\
\hline 1983 & Alicia & 3 & $117(\mathrm{~W})$ & $1.59(\mathrm{HI})^{\mathrm{j}}$ & $35(\mathrm{PA})^{\mathrm{k}}$ \\
\hline 2007 & Humberto & 1 & $35(\mathrm{~W})$ & $1.47{\text { (TPNWR })^{1}}^{1}$ & $52(\mathrm{MNWR})^{1}$ \\
\hline 1971 & Edith & 2 & $123(\mathrm{E})$ & $1.21(\mathrm{SP})^{\mathrm{m}}$ & $30(\mathrm{SP})^{\mathrm{m}}$ \\
\hline 1989 & Chantal & 1 & $36(\mathrm{~W})$ & $1.19(\mathrm{SRSP})^{\mathrm{n}}$ & $47(\mathrm{HI})^{\mathrm{n}}$ \\
\hline 1963 & Cindy & 1 & $37(\mathrm{~W})$ & $1.15(\mathrm{SP})^{\mathrm{o}}$ & $36(\mathrm{PA})^{\circ}$ \\
\hline 2003 & Claudette & 1 & $272(\mathrm{~W})$ & $1.01(\mathrm{RP})^{\mathrm{p}}$ & 45 (SRSP) $^{\mathrm{p}}$ \\
\hline 2008 & Gustav & 2 & $322(\mathrm{E})$ & $0.85(\mathrm{SP})^{\mathrm{q}}$ & $32(\mathrm{SP})^{\mathrm{q}}$ \\
\hline 1964 & Hilda & 2 & $240(\mathrm{E})$ & $0.78(\mathrm{SP})^{\mathrm{r}}$ & $30(\mathrm{SP})^{\mathrm{r}}$ \\
\hline 1989 & Jerry & 1 & $102(\mathrm{~W})$ & $0.69(\mathrm{SP})^{\mathrm{s}}$ & $41(\mathrm{GWSO})^{\mathrm{s}}$ \\
\hline 1959 & Debra & 1 & $115(\mathrm{~W})$ & $0.48(\mathrm{HI})^{\mathrm{t}}$ & $39(\mathrm{HI})^{\mathrm{t}}$ \\
\hline 1992 & Andrew & 3 & $262(\mathrm{E})$ & $0.39(\mathrm{SP})^{\mathrm{u}}$ & $22(\mathrm{PA})^{\mathrm{u}}$ \\
\hline 1985 & Juan & 1 & $245(\mathrm{E})$ & $1.1^{*}(\mathrm{SP})^{\mathrm{v}}$ & $27(\mathrm{PA})^{\mathrm{v}}$ \\
\hline 1985 & Danny & 1 & $130(\mathrm{E})$ & $0.9 *(\mathrm{SP})^{\mathrm{v}}$ & $19(\mathrm{PA})^{\mathrm{v}}$ \\
\hline 2012 & Isaac & 1 & $330(\mathrm{E})$ & N/A & $30(\mathrm{SP})^{\mathrm{w}}$ \\
\hline 1974 & Carmen & 3 & $275(\mathrm{E})$ & N/A & $\mathrm{N} / \mathrm{A}$ \\
\hline 1965 & Betsy & 3 & $330(\mathrm{E})$ & N/A & N/A \\
\hline 1977 & Babe & 1 & $267(\mathrm{E})$ & N/A & N/A \\
\hline
\end{tabular}

Tide and wind record locations were selected for close proximity to MNWR study area.

${ }^{2}$ Storm tide is normal tide plus storm surge (NAVD88).

Location key: SP: Sabine Pass, G: Galveston, PA: Port Arthur, BAP: Beaumont Air Port, HI:

High Island, TPNWR: Texas Point National Wildlife Refuge, MNWR: McFaddin National

Wildlife Refuge, SRSP: Sea Rim State Park, RP: Rollover Pass.

* Height above normal tide

N/A: significant hurricane-related conditions not recorded in vicinity of study area.

Wind and tide data sources: ${ }^{\mathrm{a}}$ Berg, 2009;; ${ }^{\mathrm{b}}$ Knabb et al., 2006; ${ }^{\mathrm{c}}$ Moore et al., 1957;

${ }^{\mathrm{d}}$ Landreneau and Shamburger, 2009; ${ }^{\mathrm{e}}$ Ho and Miller, 1982; ${ }^{\mathrm{f}}$ U.S. Weather Bureau, 1961;

${ }^{\mathrm{g}}$ National Weather Service, 2016; ${ }^{\mathrm{h}}$ Lawrence, 1987; ${ }^{\mathrm{i}}$ Lawrence, 2002; ${ }^{\mathrm{j}}$ Case and Gerrish, 1983;

${ }^{\mathrm{k}}$ National Hurricane Center, 1983; ${ }^{1}$ Blake, 2007; ${ }^{\mathrm{m}}$ Simpson and Hope, 1971; ${ }^{\mathrm{n}}$ Case and

Mayfield, 1990; ${ }^{\circ}$ U.S. Weather Bureau, 1963; ${ }^{\mathrm{p}}$ Beven, 2003; ${ }^{\mathrm{q}}$ Beven and Kimberlain, 2014;

${ }^{\mathrm{r}}$ Dunn et al., 1964; ${ }^{\mathrm{s}}$ Case and Mayfield, 1990; ${ }^{\mathrm{t}}$ U.S. Weather Bureau, 1959; ${ }^{\mathrm{u}}$ Rappaport, 1993;

${ }^{\mathrm{v}}$ Case, 1985; ${ }^{\mathrm{w}}$ Berg, 2013. 
Table 3.

Marsh and hurricane deposit thicknesses ${ }^{1}$ (cm): $1957-2014$.

\begin{tabular}{|c|c|c|c|c|c|c|c|c|c|}
\hline Core & $\begin{array}{l}\text { Marsh: } \\
\text { 2008- } \\
2014\end{array}$ & $\begin{array}{l}\text { Hurricane } \\
\text { Ike } \\
\text { Deposit }\end{array}$ & $\begin{array}{l}\text { Marsh: } \\
2005- \\
2008\end{array}$ & $\begin{array}{l}\text { Hurricane } \\
\text { Rita } \\
\text { Deposit }\end{array}$ & $\begin{array}{l}\text { Marsh: } \\
1961 \text { - } \\
2005\end{array}$ & $\begin{array}{l}\text { Hurricane } \\
\text { Carla } \\
\text { Deposit }\end{array}$ & $\begin{array}{l}\text { Marsh: } \\
1957- \\
1961\end{array}$ & $\begin{array}{l}\text { Hurricane } \\
\text { Audrey } \\
\text { Deposit }\end{array}$ & $\begin{array}{l}\text { Carla and } \\
\text { Audrey } \\
\text { Combined }^{2}\end{array}$ \\
\hline 1 & 0 & 37.8 & 3.5 & 15.3 & - & - & - & - & - \\
\hline 2 & 0 & 48.7 & 5.8 & 18.6 & - & - & - & - & - \\
\hline 3 & 0 & 56.4 & 2.3 & 11.5 & - & - & - & - & - \\
\hline 4 & 0 & 40.0 & 8.8 & 12.5 & - & - & - & - & - \\
\hline 5 & 0 & 22.5 & 6.4 & 13.9 & - & - & - & - & - \\
\hline T5-5 & 0 & 24.6 & 7.5 & 10.7 & 18.2 & 3.7 & 0.5 & 1.6 & - \\
\hline 6 & 0 & 14.3 & 4.1 & 8.2 & 16.3 & 2.0 & 0.5 & 2.6 & - \\
\hline 7 & 1.0 & 9.2 & 7.1 & 4.1 & 19.4 & - & - & - & 5.1 \\
\hline 8 & 0 & 12.5 & - & - & - & 2.1 & 1.0 & 5.2 & - \\
\hline 9 & 2.2 & 9.7 & 5.4 & 5.4 & 15.1 & 2.2 & 0.5 & 0.5 & - \\
\hline 10 & 2.2 & 4.5 & 7.8 & 4.5 & 11.2 & - & - & - & 4.5 \\
\hline 11 & 0 & 5.9 & - & - & - & - & - & - & - \\
\hline 12 & 2.1 & 3.2 & - & - & - & - & - & - & - \\
\hline 13 & 2.2 & 2.2 & 11.9 & 3.2 & 19.4 & - & - & - & 5.4 \\
\hline
\end{tabular}

${ }^{1}$ adjusted to remove compaction, which presumably introduced small uncertainties in estimated thicknesses; ${ }^{2}$ hurricane deposits apparently combined by bioturbation. 
Table 4.

Marsh average annual sedimentation rates (cm/year)

\begin{tabular}{ccccc}
\hline Core & $2008-2014^{1}$ & $2005-2008^{2}$ & $1961-2005^{3}$ & $1957-1961^{4}$ \\
\hline 1 & 0.00 & 1.19 & - & - \\
2 & 0.00 & 1.95 & - & - \\
3 & 0.00 & 0.77 & - & - \\
4 & 0.00 & 2.95 & - & - \\
5 & 0.00 & 2.16 & - & - \\
T5-5 & 0.00 & 2.52 & 0.41 & 0.13 \\
6 & 0.00 & 1.37 & 0.37 & 0.12 \\
7 & 0.17 & 2.40 & 0.44 & - \\
8 & 0.00 & - & - & 0.25 \\
9 & 0.36 & 1.82 & 0.34 & 0.13 \\
10 & 0.38 & 2.64 & 0.25 & - \\
11 & 0.00 & - & - & - \\
12 & 0.35 & - & - & - \\
13 & 0.36 & 3.64 & 0.44 & - \\
Average & 0.12 & 2.13 & 0.38 & 0.16 \\
\hline
\end{tabular}

${ }^{1} 5.92$ years; ${ }^{2} 2.97$ years; ${ }^{3} 44.04$ years; ${ }^{4} 4.21$ years 
Table 5.

Hurricane and non-hurricane sedimentation ${ }^{1}$

\begin{tabular}{rcccccc}
\hline Core $^{2}$ & $\begin{array}{l}\text { Depth to Base of } \\
\text { Hurricane Audrey } \\
\text { Deposit }(\mathrm{cm})^{3}\end{array}$ & $\begin{array}{l}\text { Depth to Base of } \\
\text { Hurricane Rita } \\
\text { Deposit }(\mathrm{cm})^{4}\end{array}$ & $\begin{array}{l}\text { Hurricane } \\
\text { Sedimentation } \\
(\mathrm{cm})^{5}\end{array}$ & $\begin{array}{l}\text { Non-Hurricane } \\
\text { Sedimentation } \\
(\mathrm{cm})^{6}\end{array}$ & $\begin{array}{l}\text { \% Hurricane } \\
\text { Sedimentation }\end{array}$ & $\begin{array}{l}\text { \% Non-Hurricane } \\
\text { Sedimentation }\end{array}$ \\
\hline 1 & - & 56.6 & 53.1 & 3.5 & 93.8 & 6.3 \\
2 & - & 73.1 & 67.3 & 5.8 & 92.1 & 7.9 \\
3 & - & 70.2 & 67.9 & 2.3 & 96.7 & 3.3 \\
4 & - & 61.3 & 52.5 & 8.8 & 85.7 & 14.3 \\
5 & - & 42.8 & 36.4 & 6.4 & 85.0 & 15.0 \\
T5-5 & 66.9 & 42.8 & 40.7 & 26.2 & 60.8 & 39.2 \\
6 & 47.9 & 26.5 & 27.0 & 20.9 & 56.4 & 43.6 \\
7 & 45.9 & 21.4 & 18.4 & 27.5 & 40.0 & 60.0 \\
8 & 44.7 & - & 19.7 & 25.0 & 44.2 & 55.8 \\
9 & 41.0 & 22.7 & 17.8 & 23.2 & 43.4 & 56.6 \\
10 & 34.7 & 19.0 & 13.4 & 21.3 & 38.7 & 61.3 \\
\hline
\end{tabular}

' adjusted to remove compaction; ${ }^{2}$ cores 11 and 12 did not contain Hurricane Audrey's or Rita's deposit and are excluded; ${ }^{3}$ used to find hurricane/non-hurricane sedimentation in cores T5-5 10 and core $13 ;{ }^{4}$ used to find hurricane/non-hurricane sedimentation in cores $1-5 ;{ }^{5}$ combined thickness of hurricane sand beds; ${ }^{6}$ combined thickness of marsh deposits. 

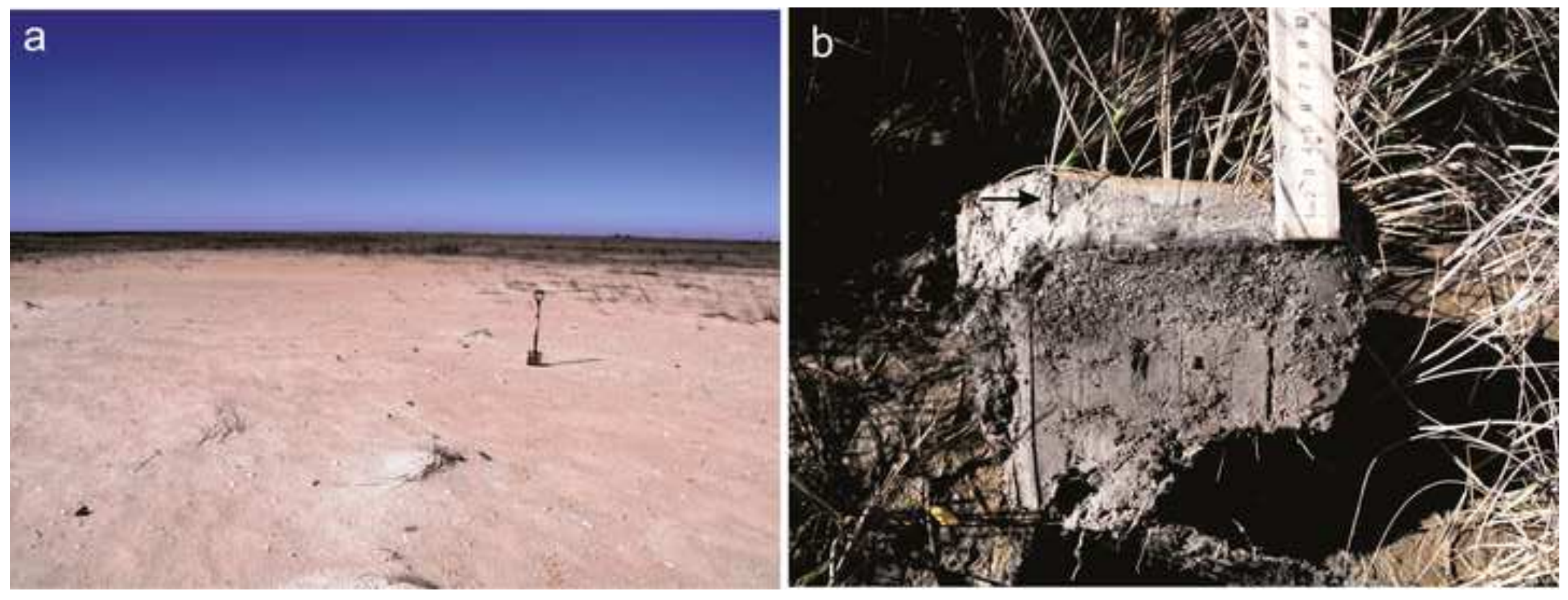
T5-5

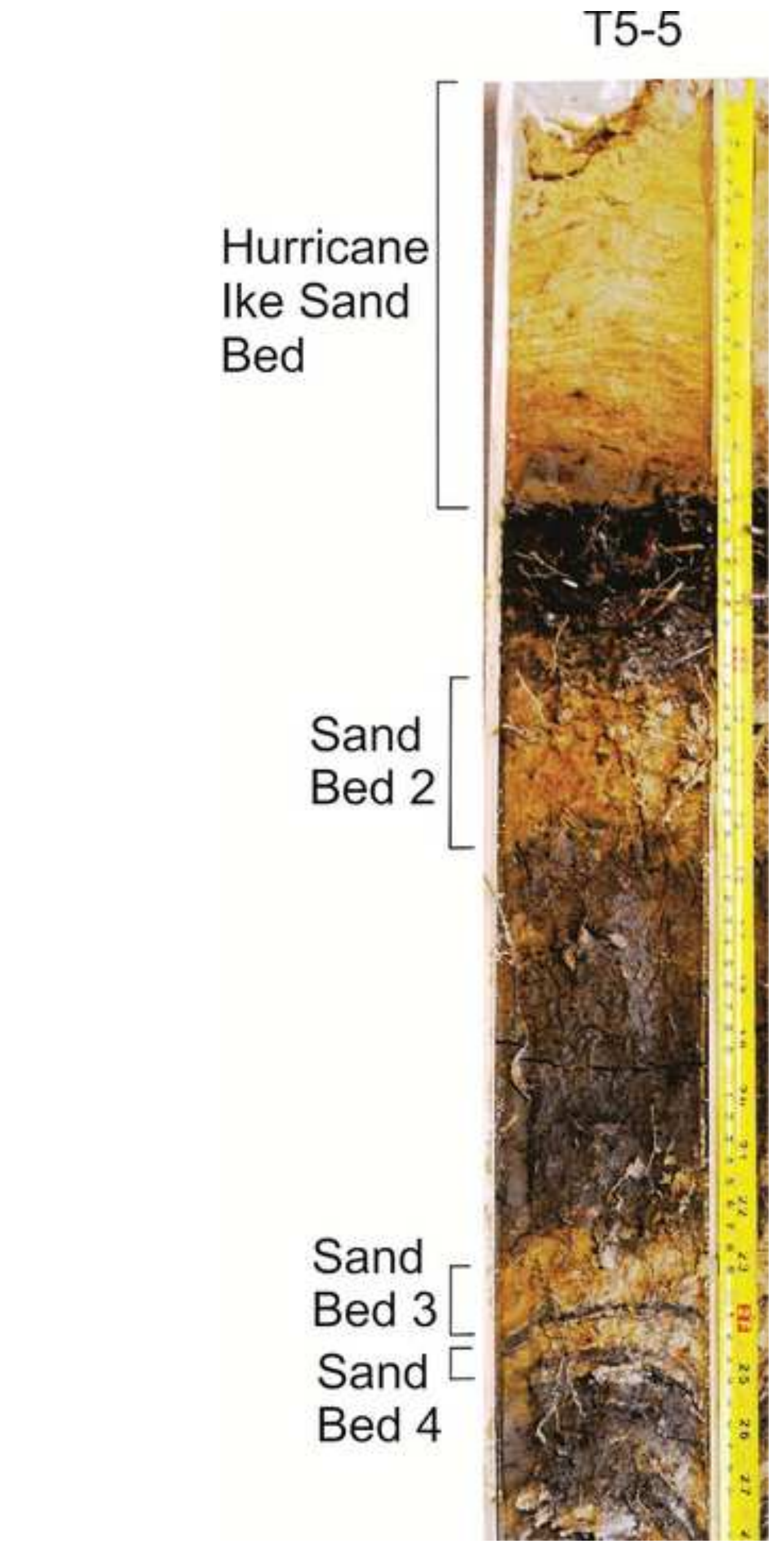

Figure 2 (Color)

.




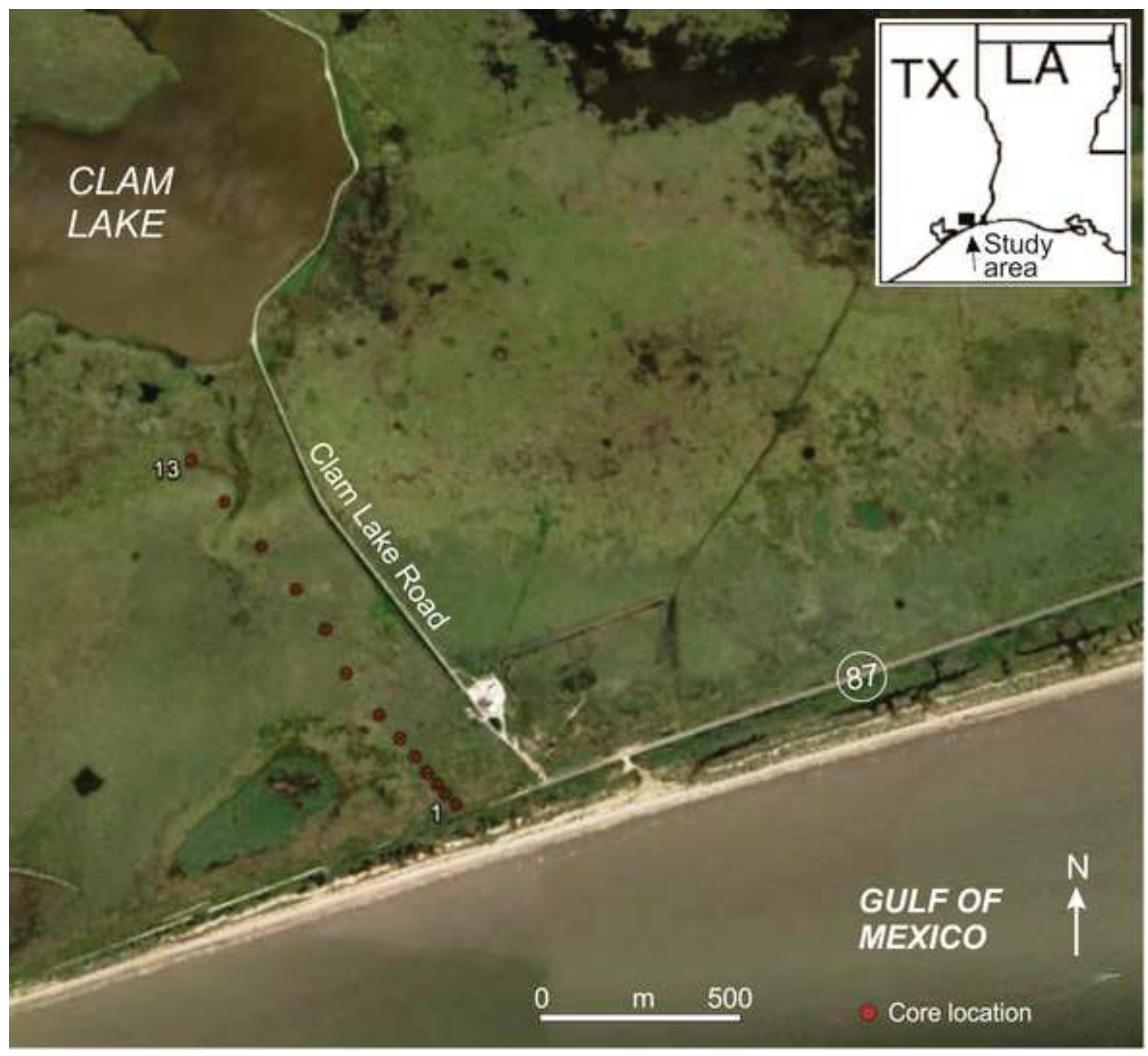

\section{LAKE}

0

GULF OF

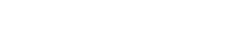


Figure 4 (Color)
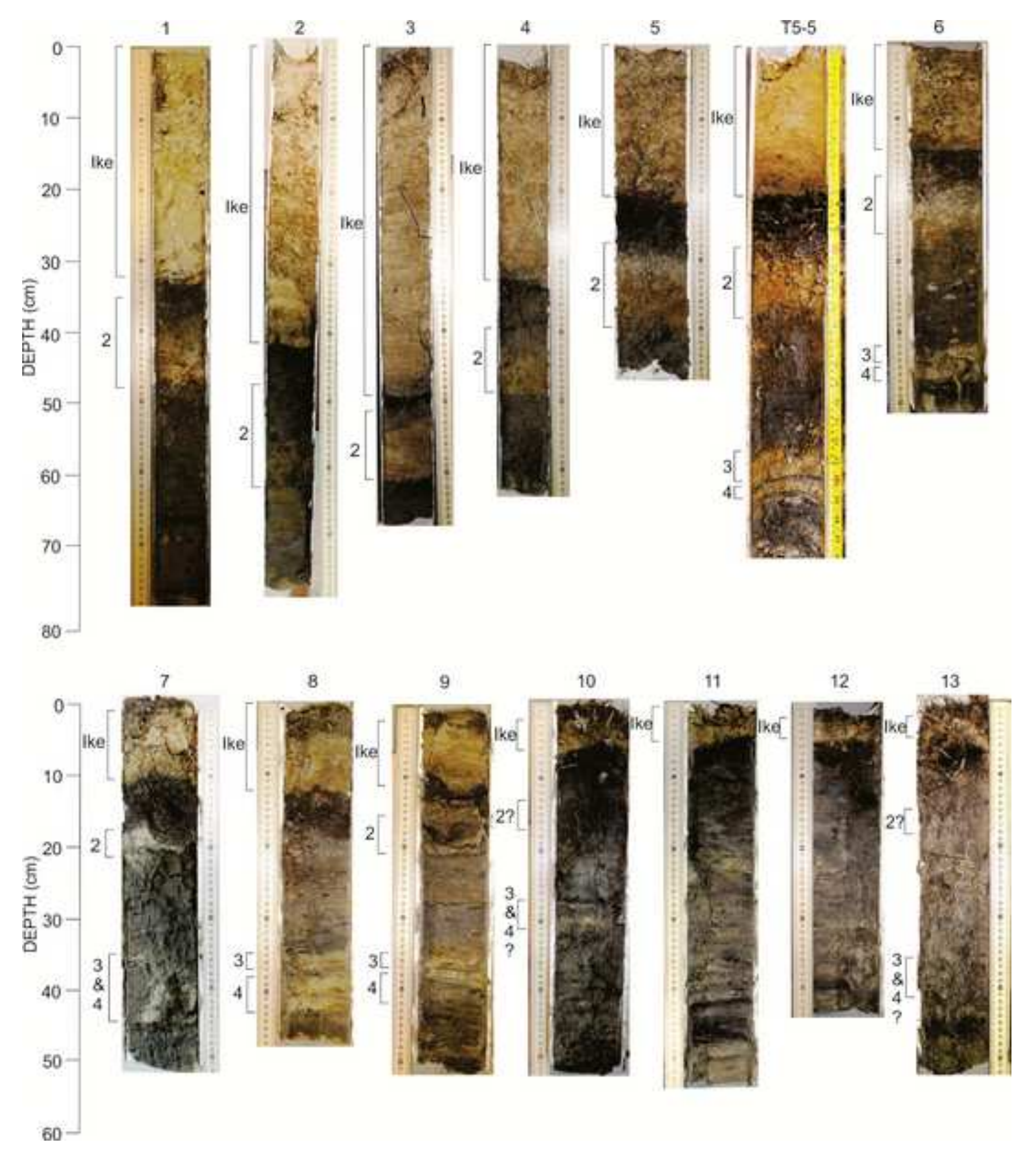


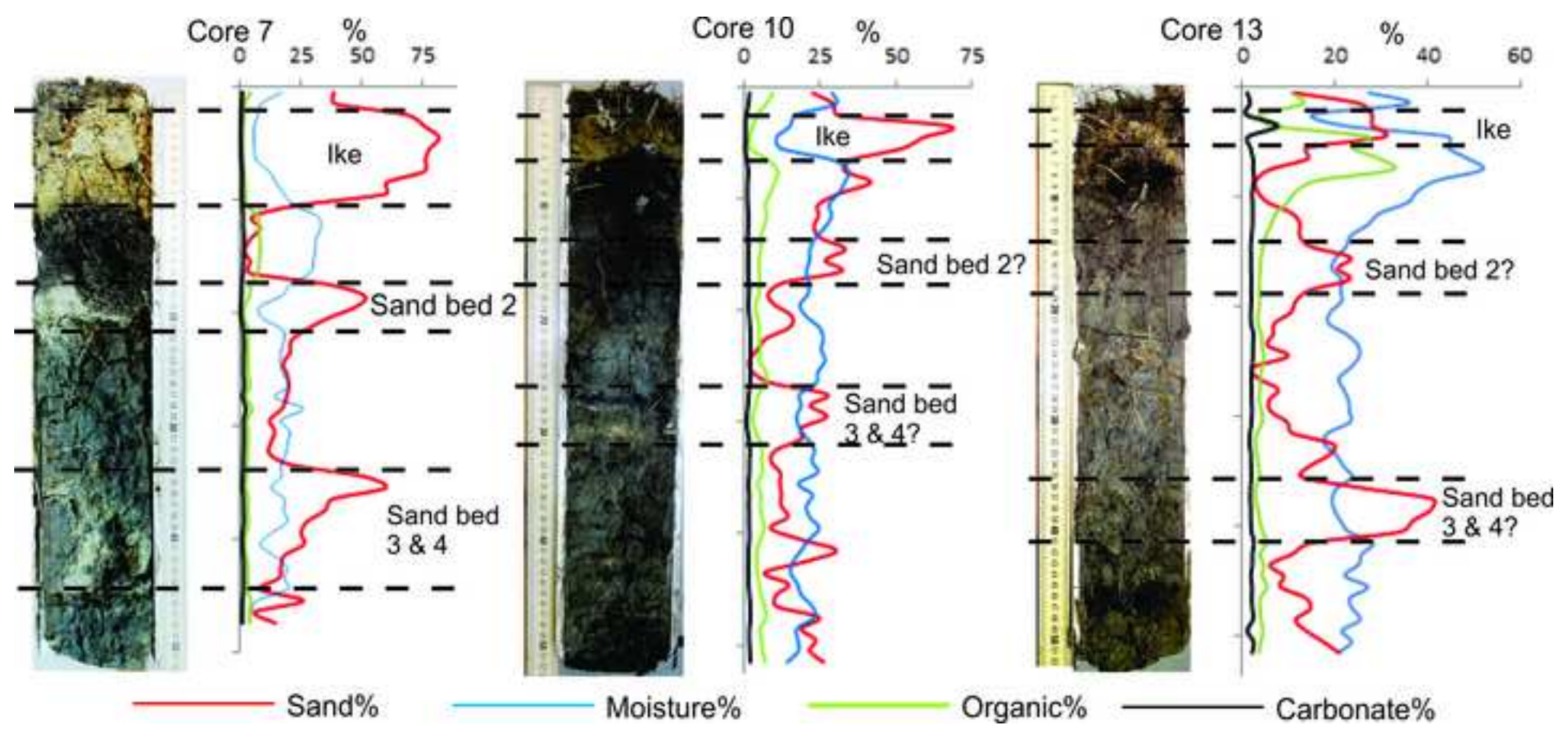




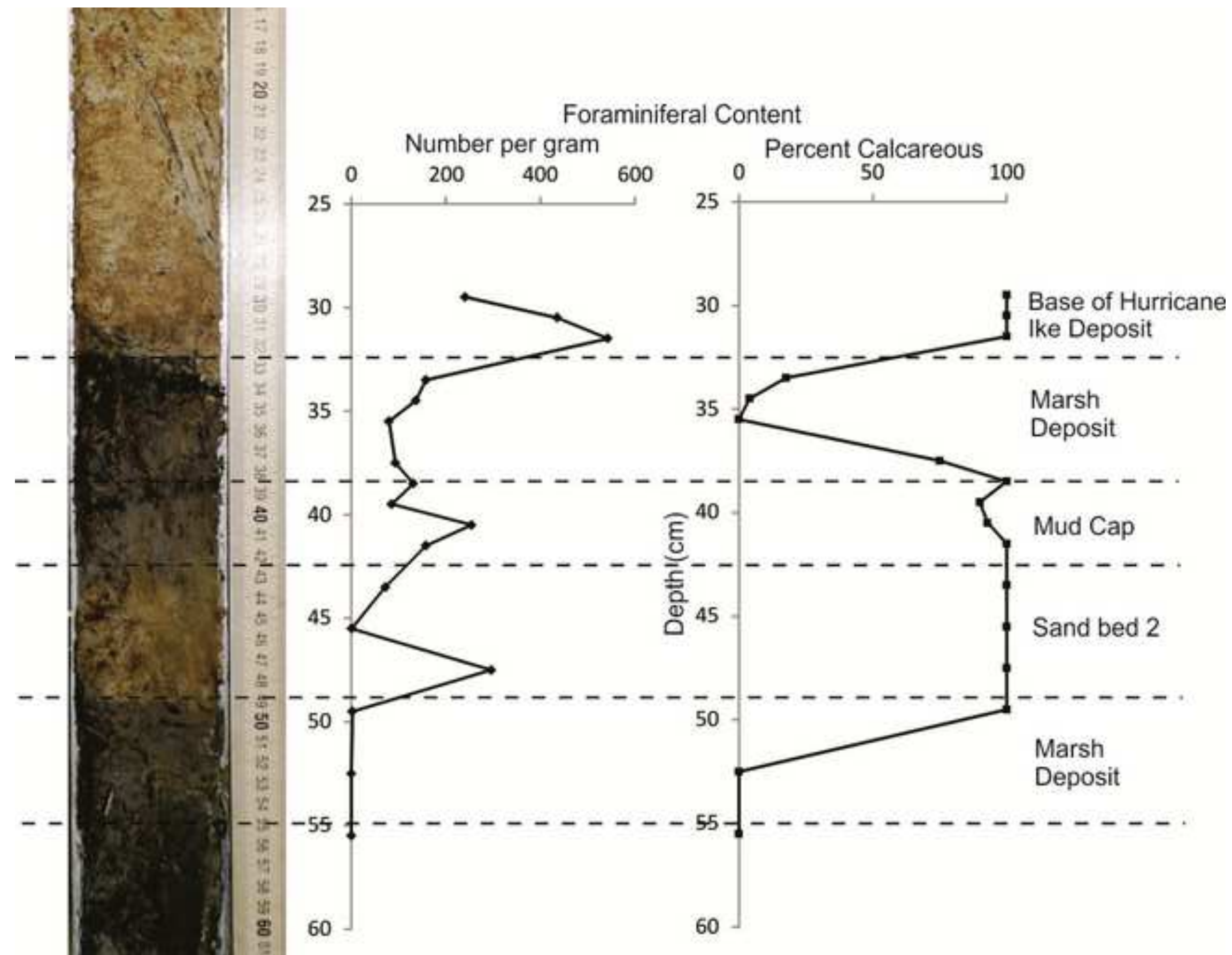




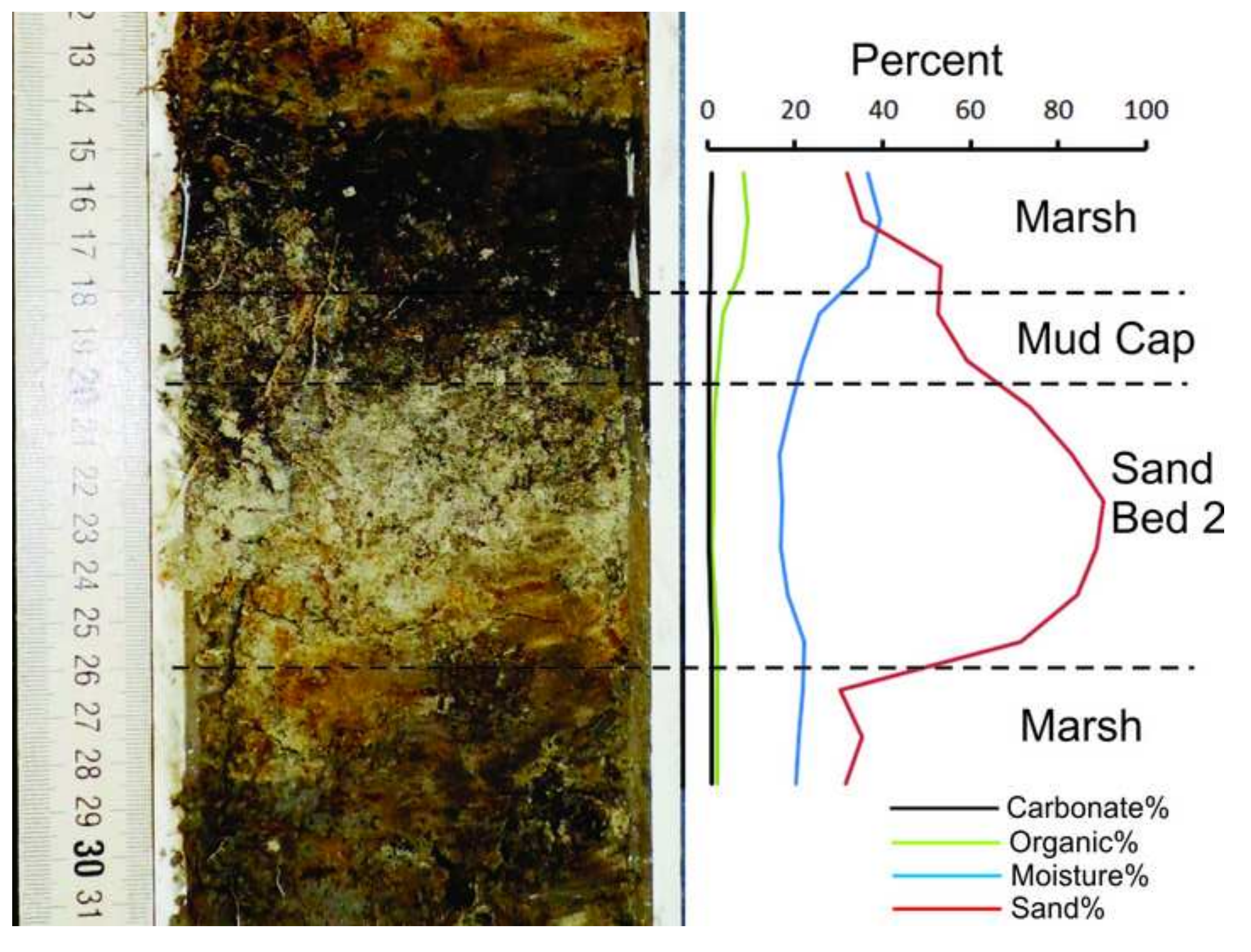

Sand \%

\section{7}

$$
\text { 年 }
$$
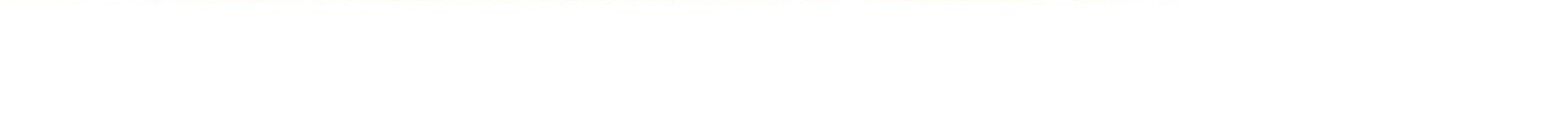
Figure 8 (Color)

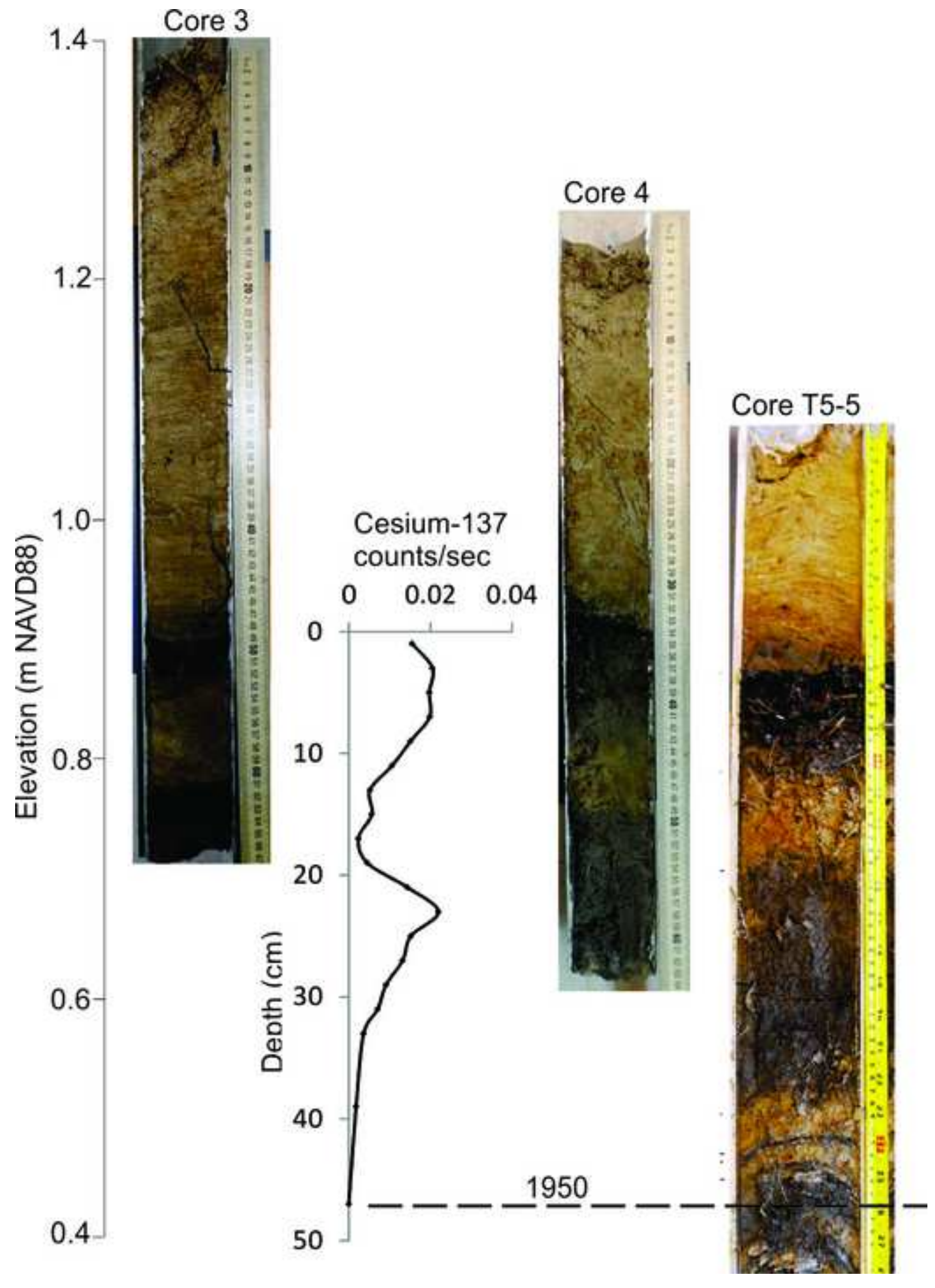




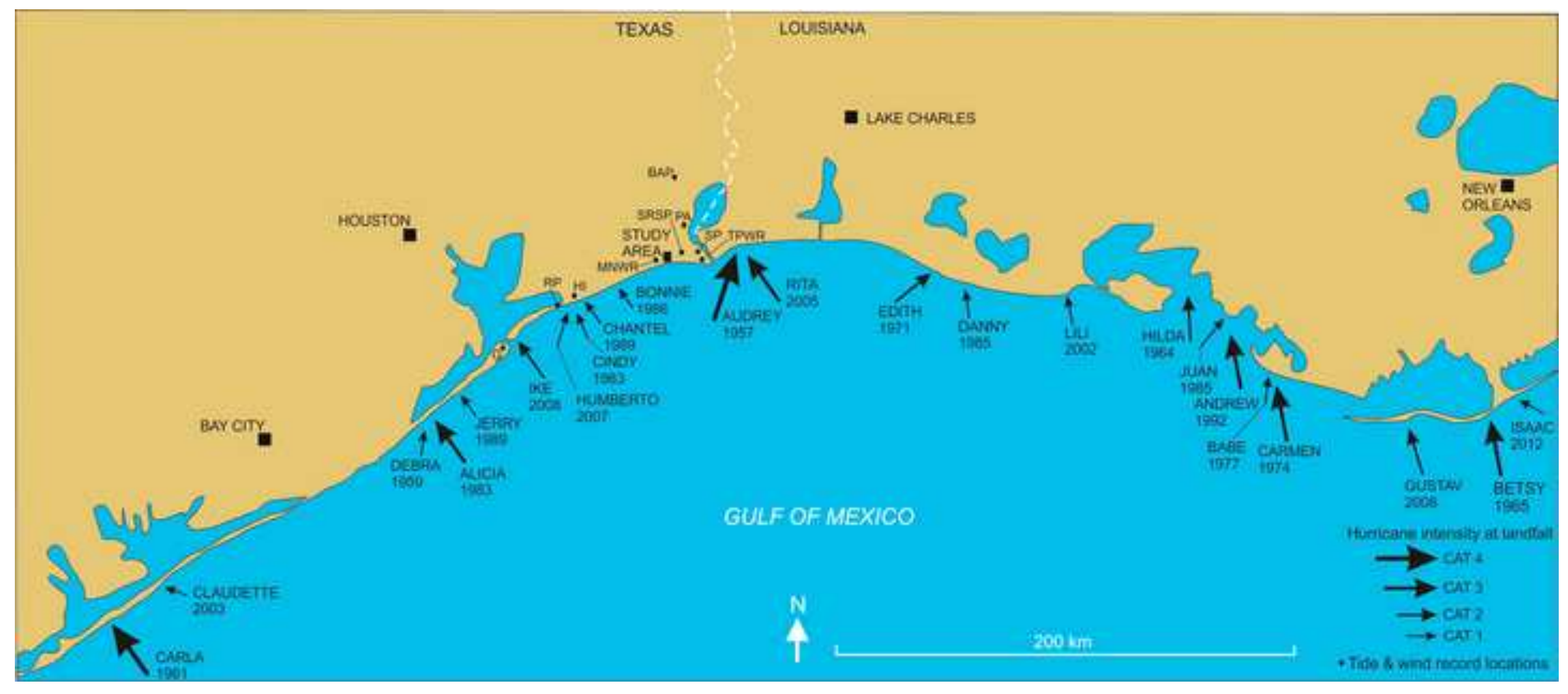




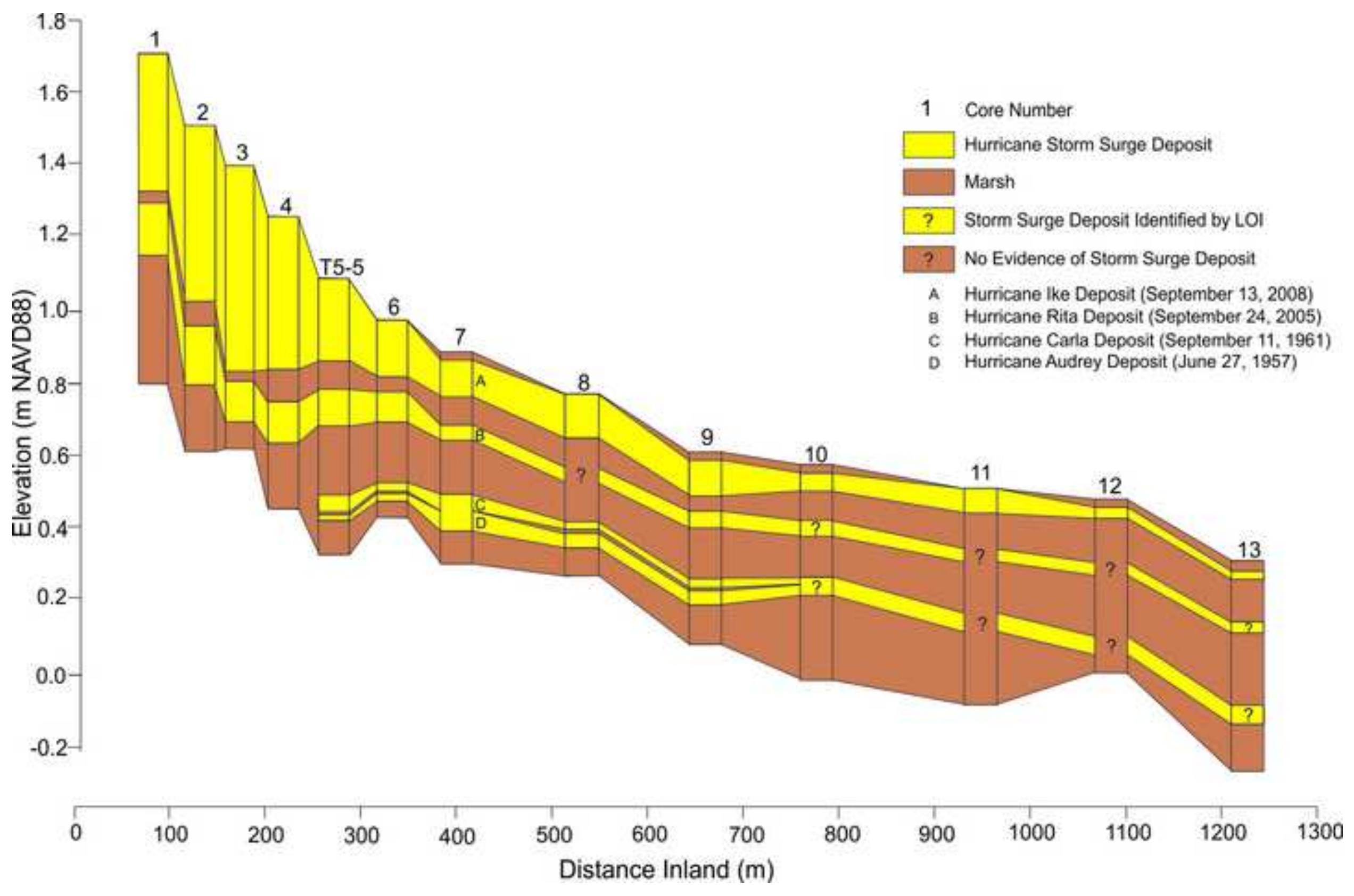



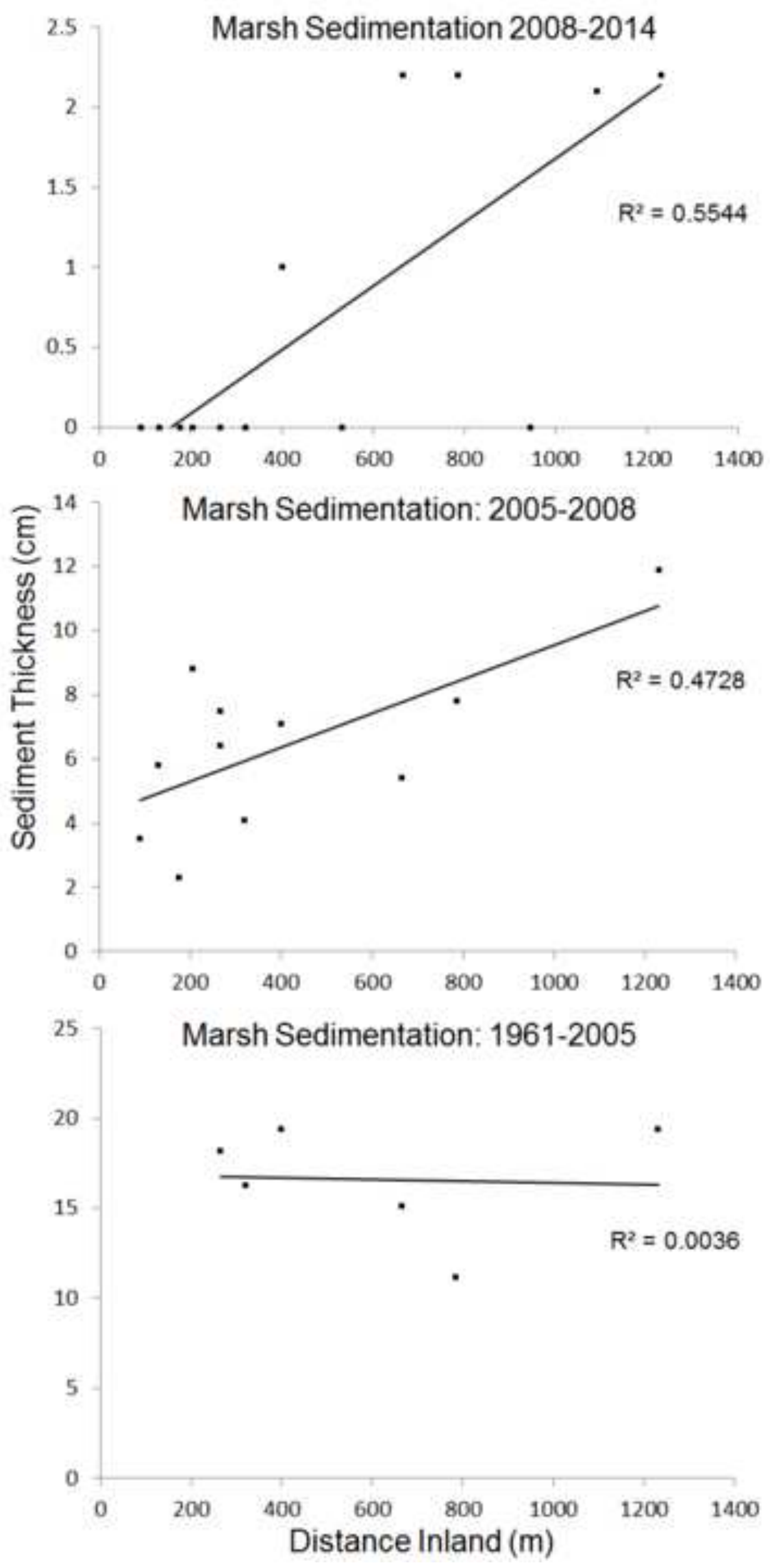


\section{Figure 1 (Greyscale)}
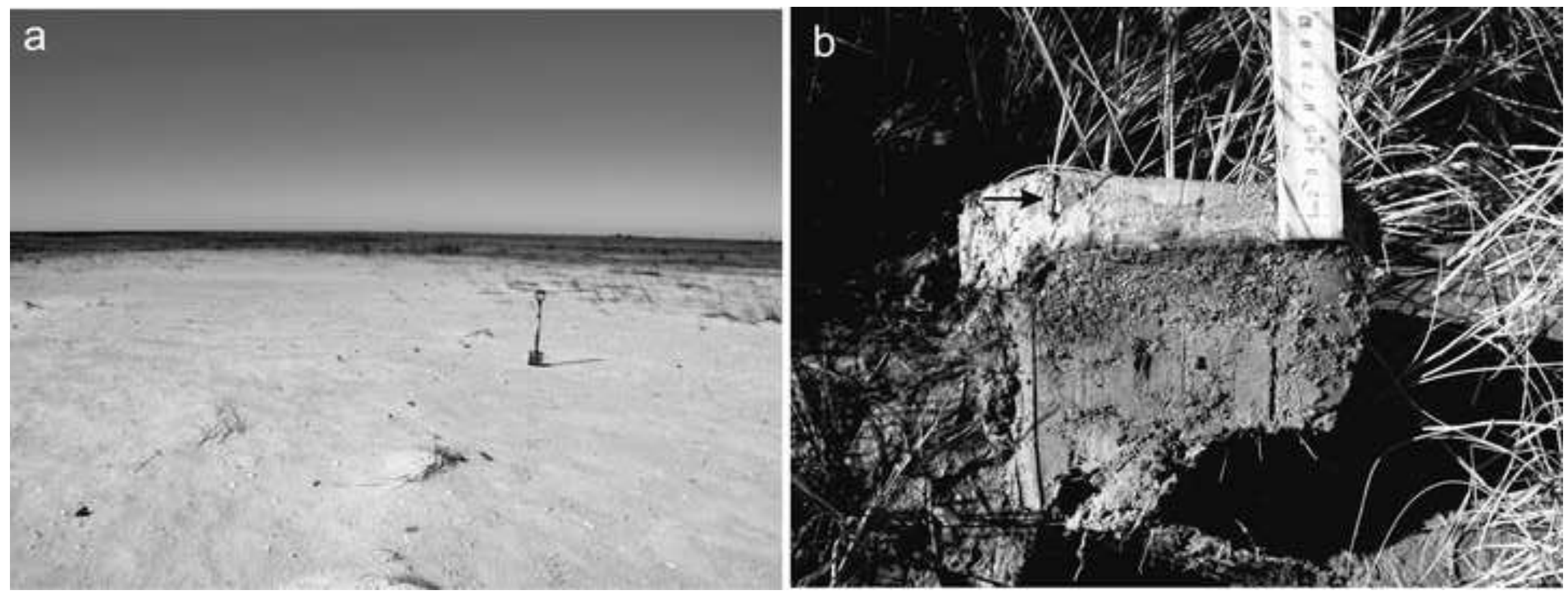
Figure 2 (Greyscale)

T5-5
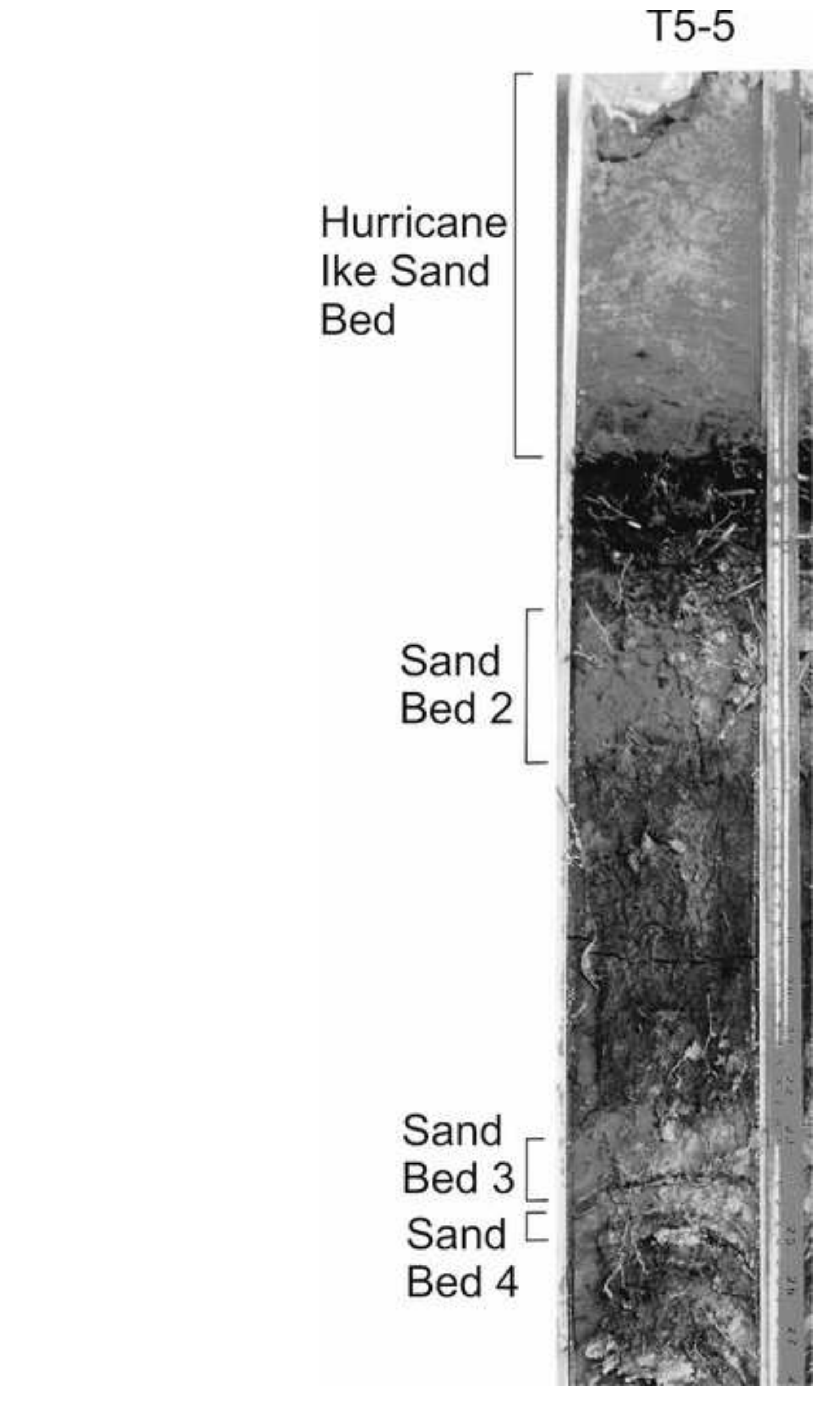


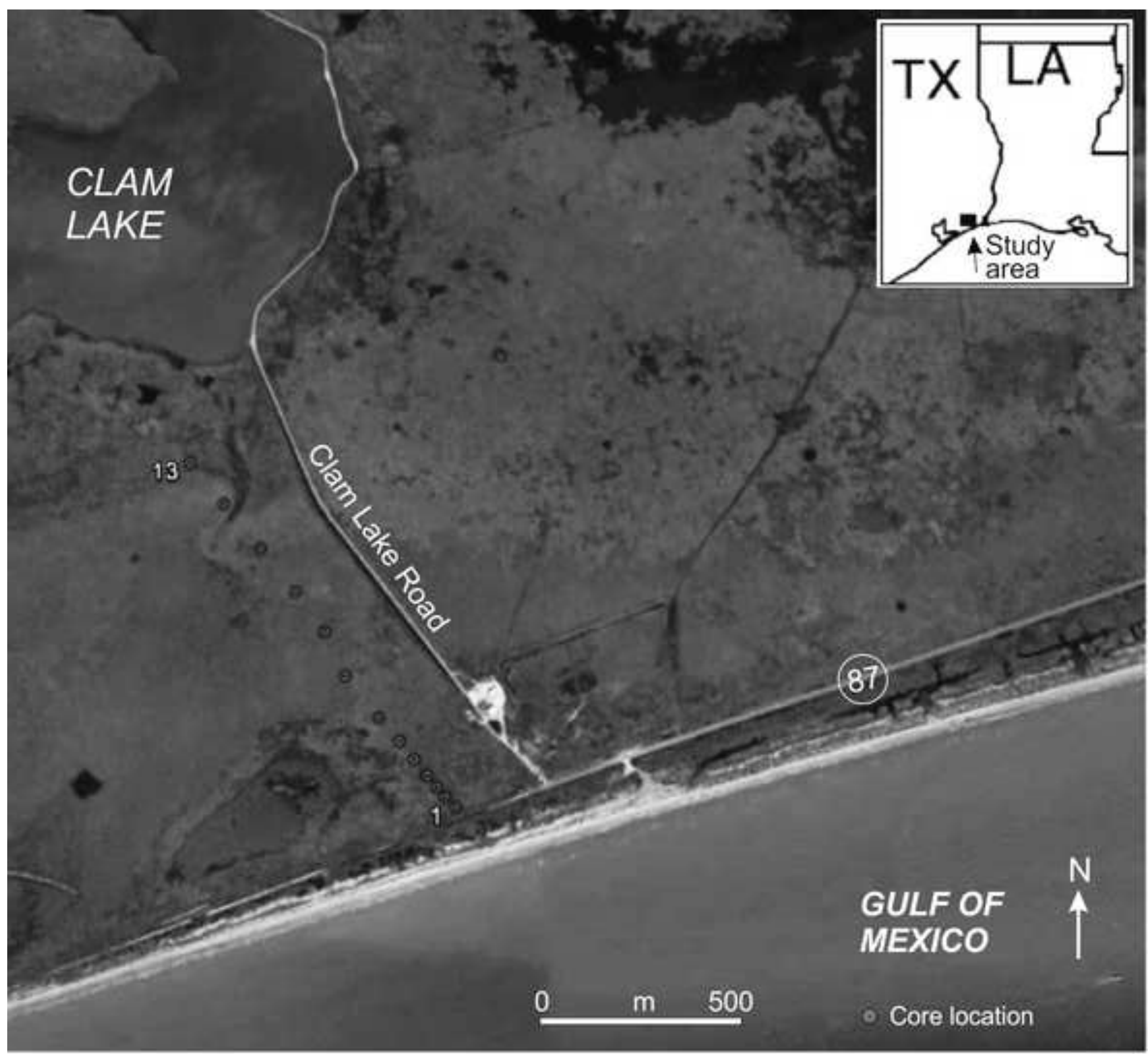


Figure 4 (Greyscale)
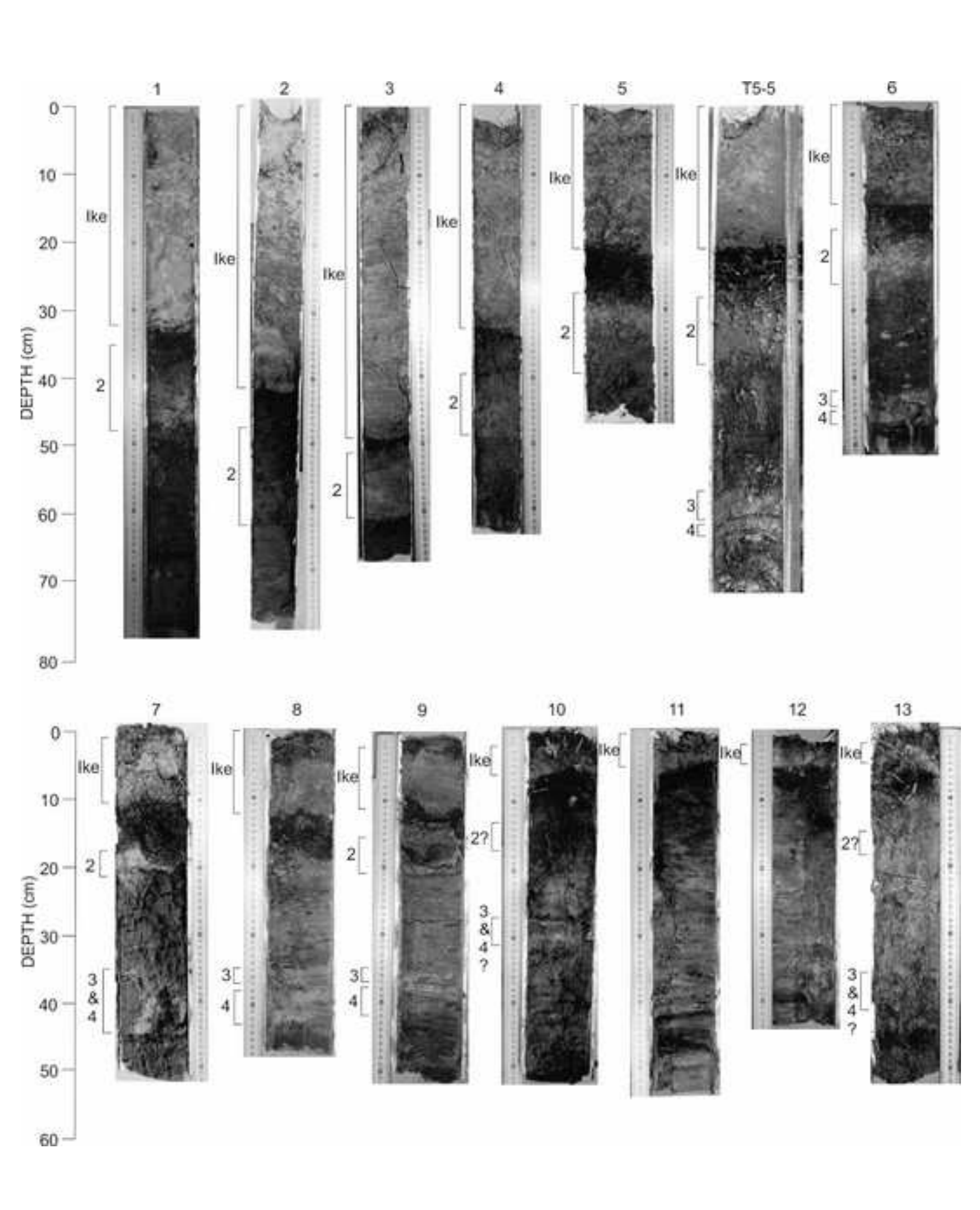

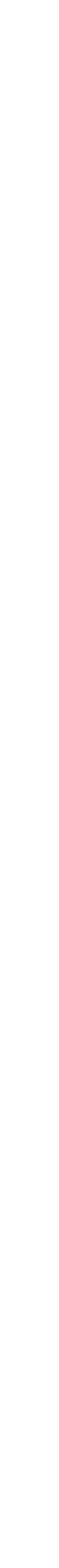


Core $7 \quad \%$

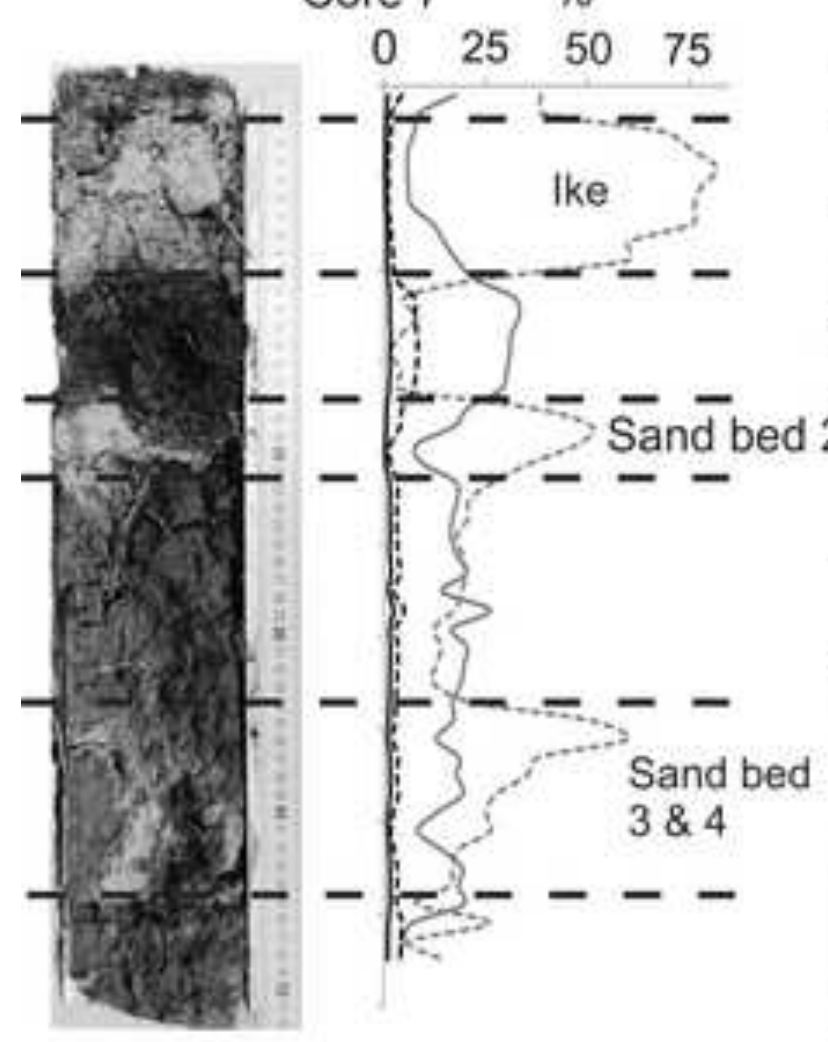

Sand $\%$

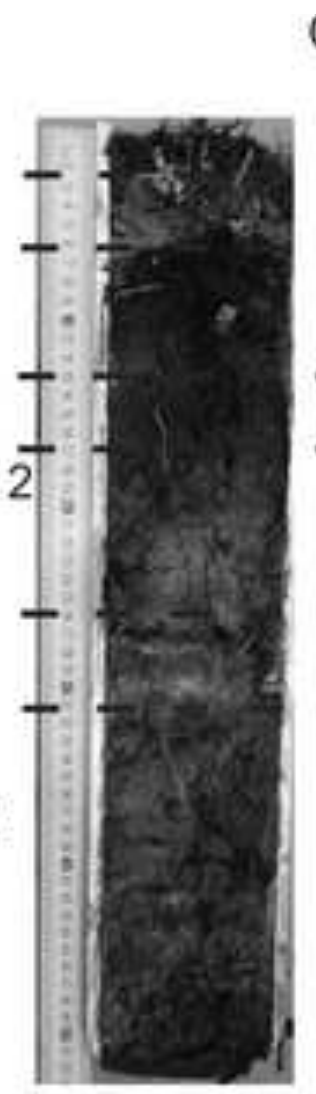

Core 10

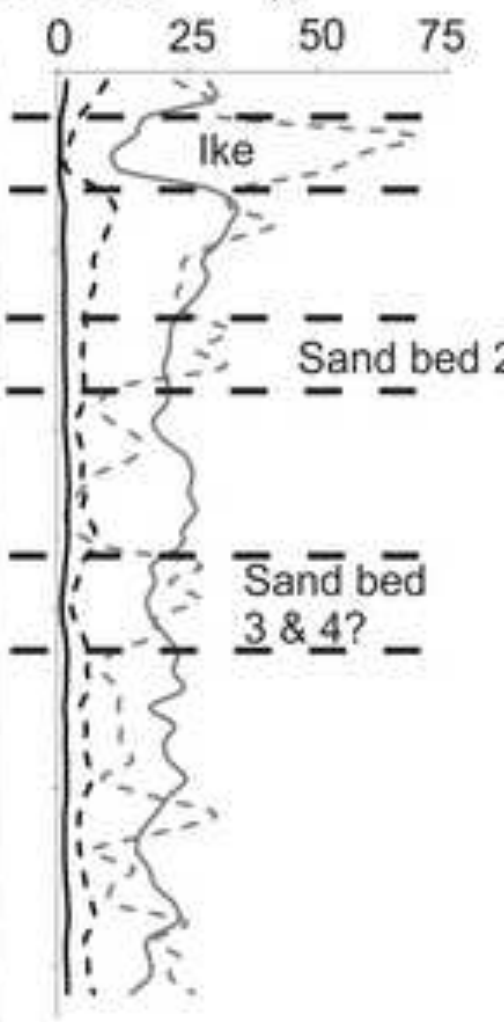

Moisture\%

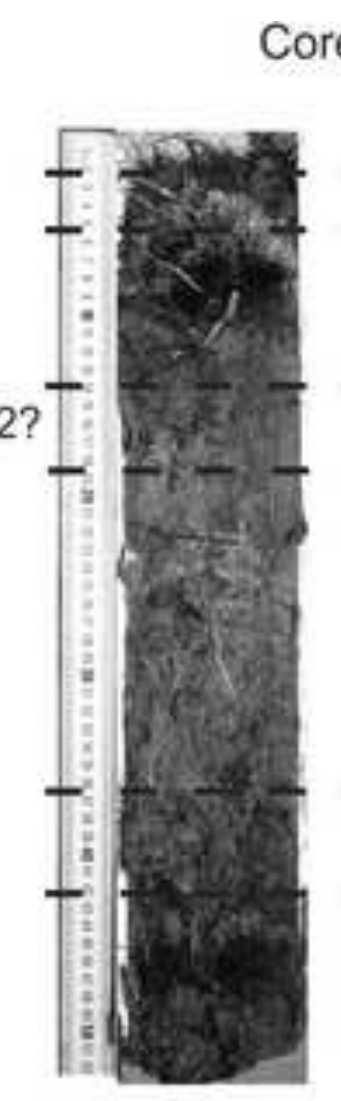

Organic\%

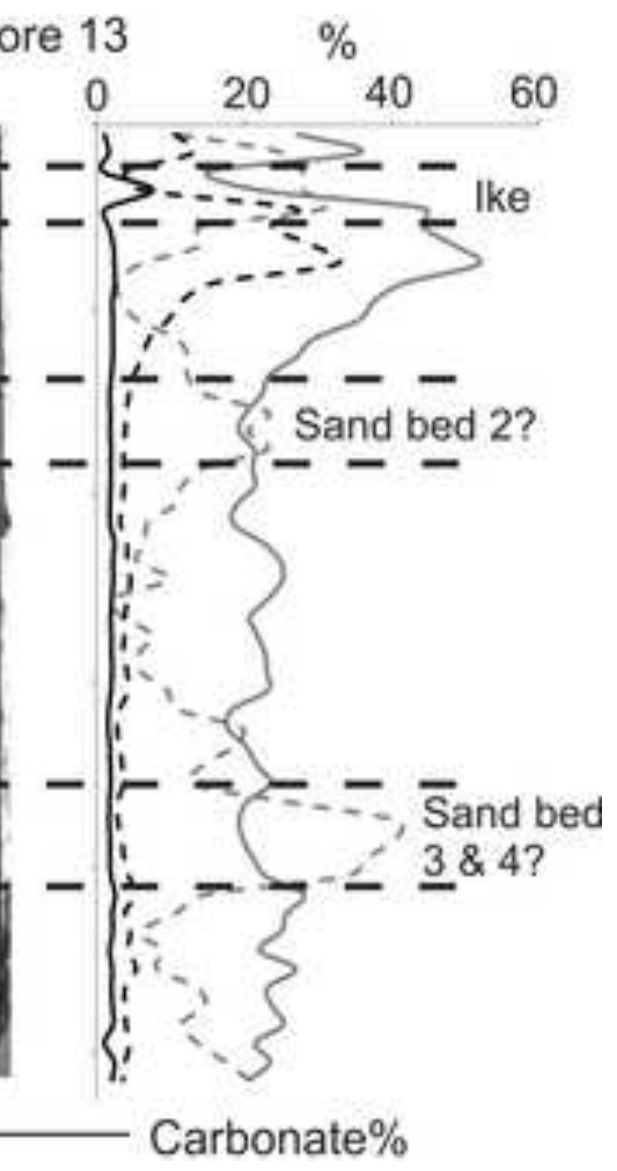




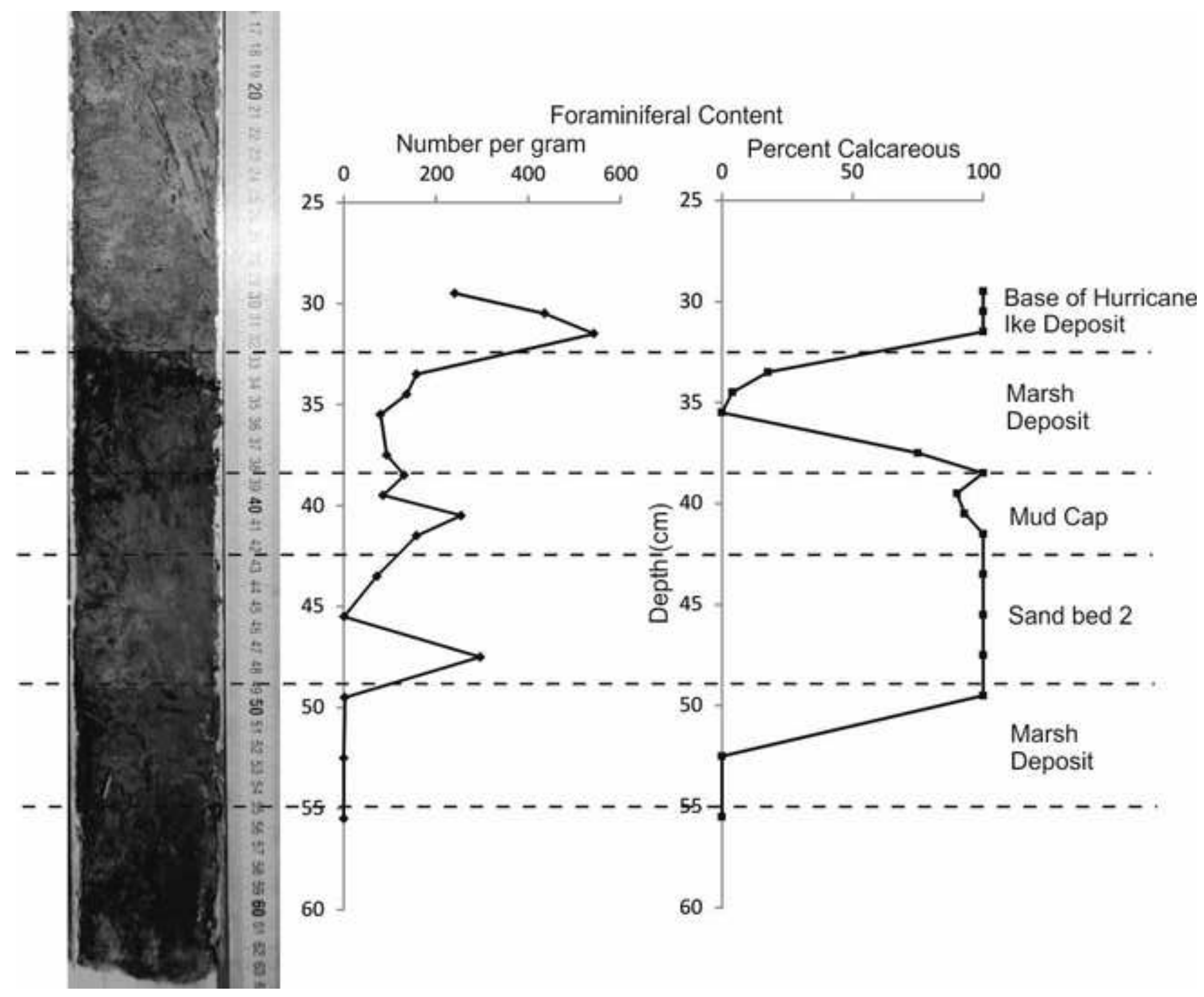


Figure 7 (Greyscale)

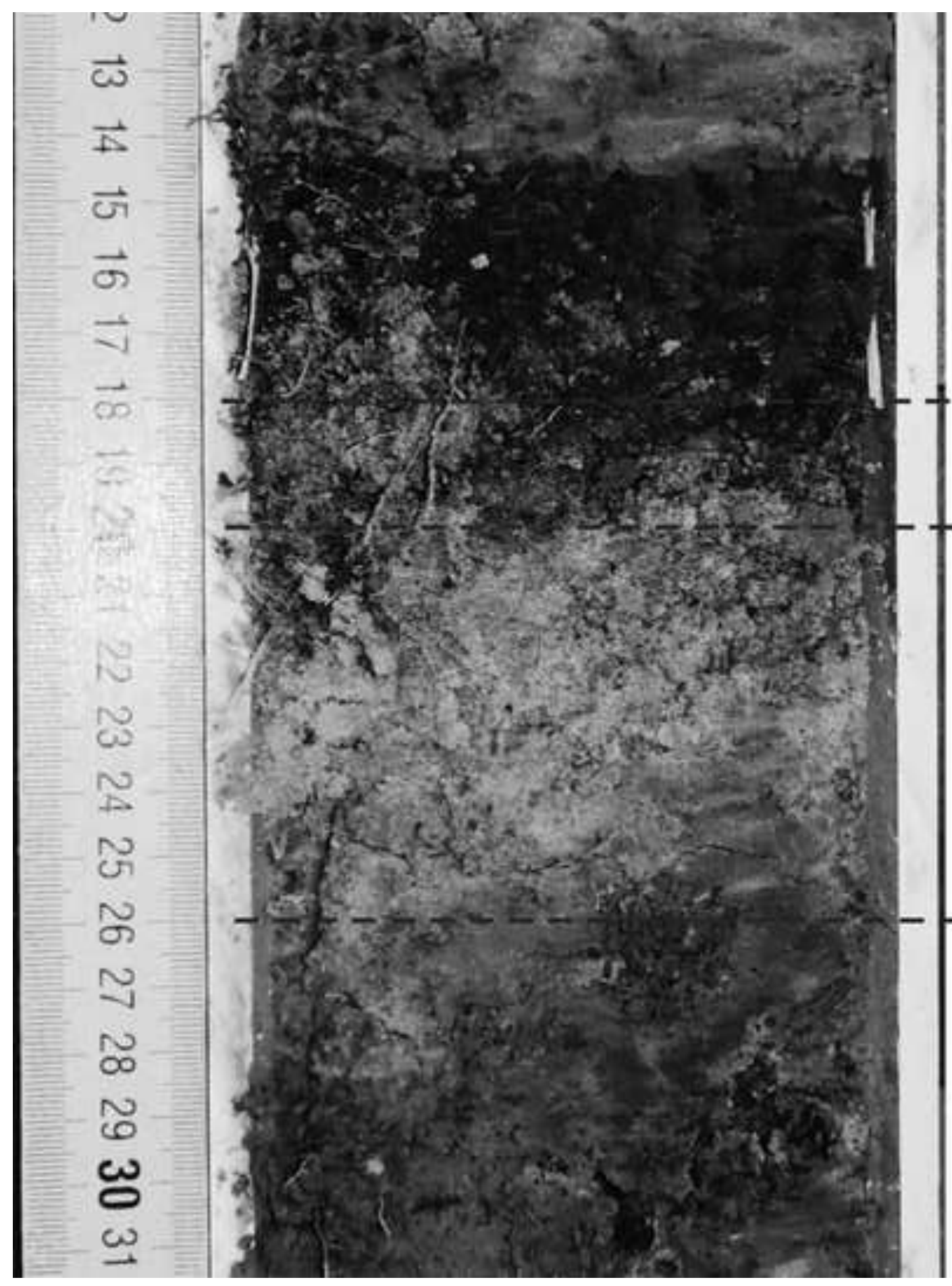

\section{Percent}

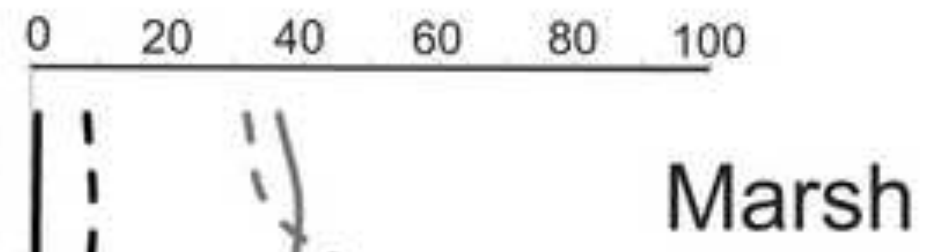

Mud Cap

.

Sand 'Bed 2

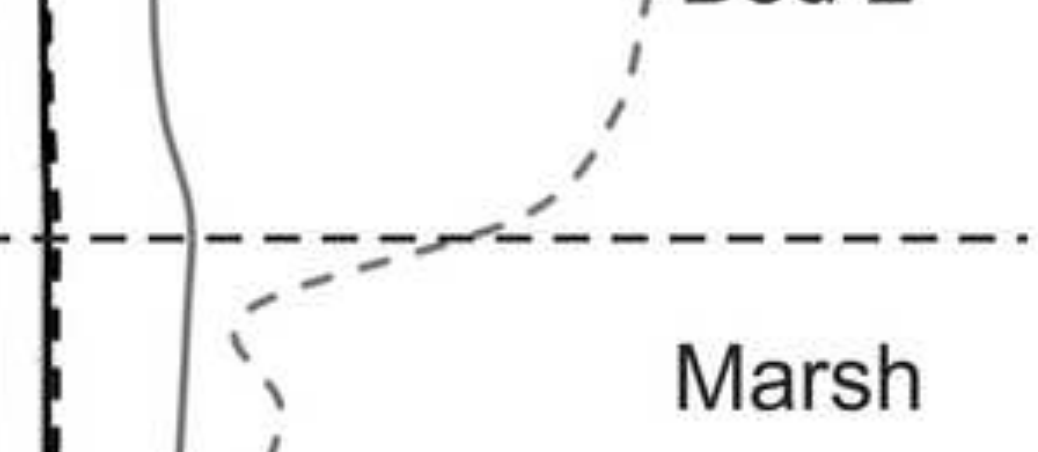

- Carbonate $\%$

- - - Organic\% Moisture\%

- - - Sand $\%$ 


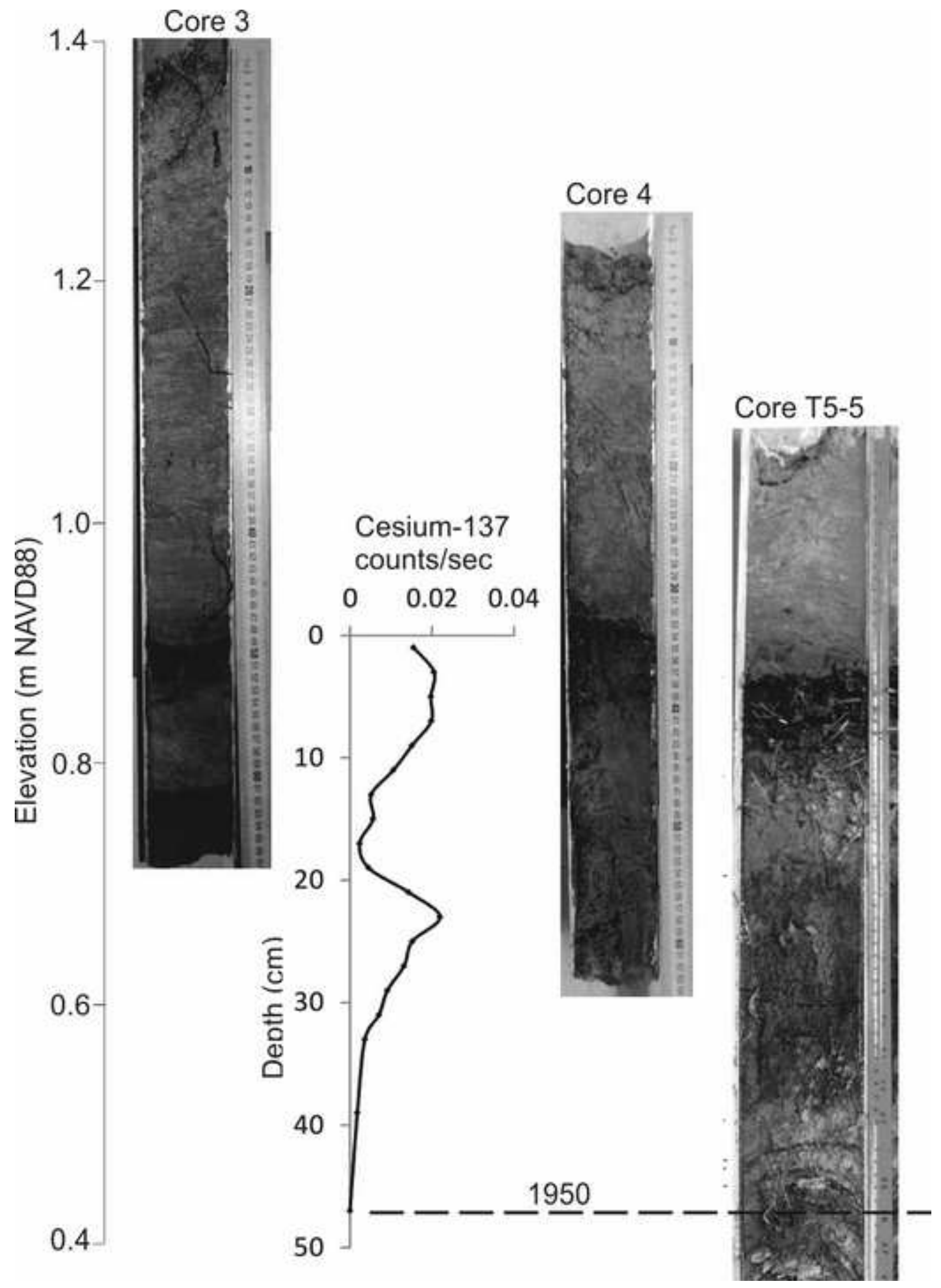




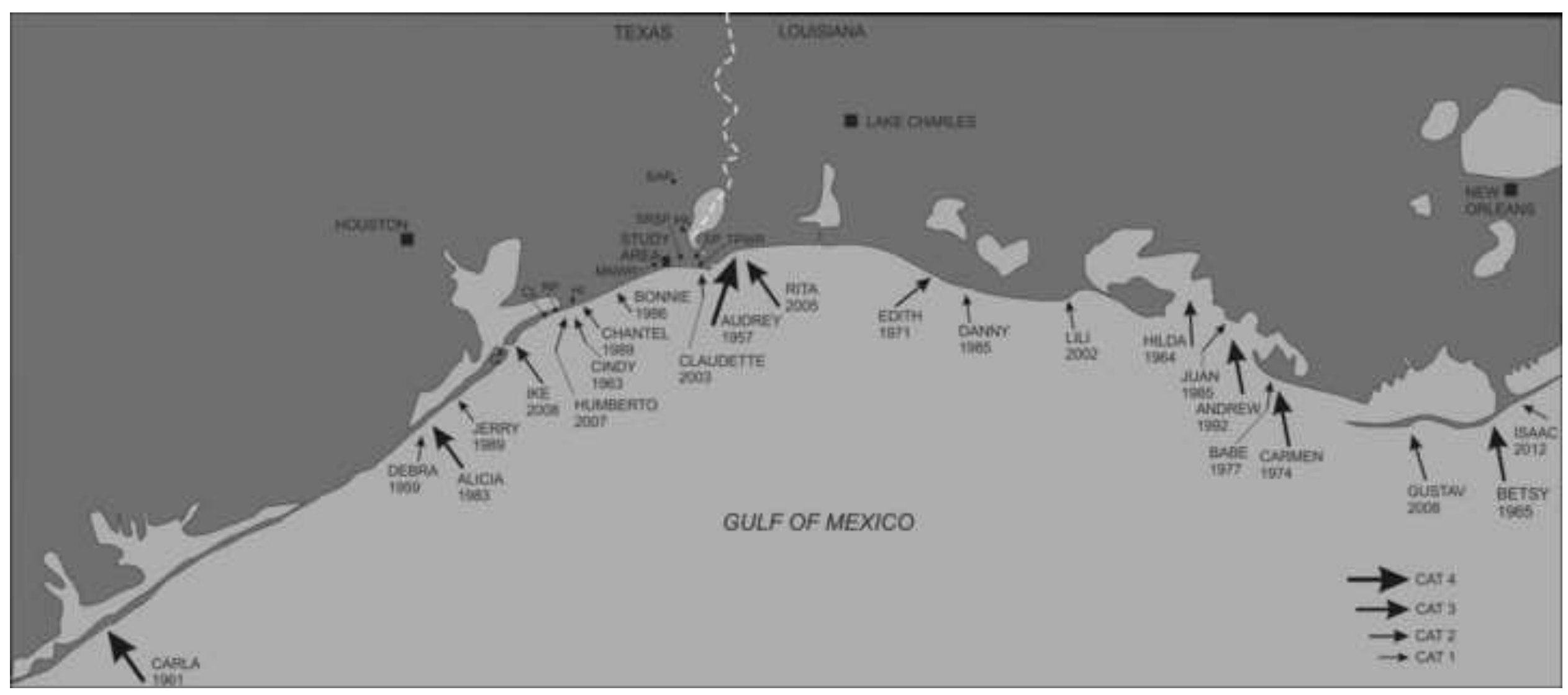


Figure 10 (Greyscale)

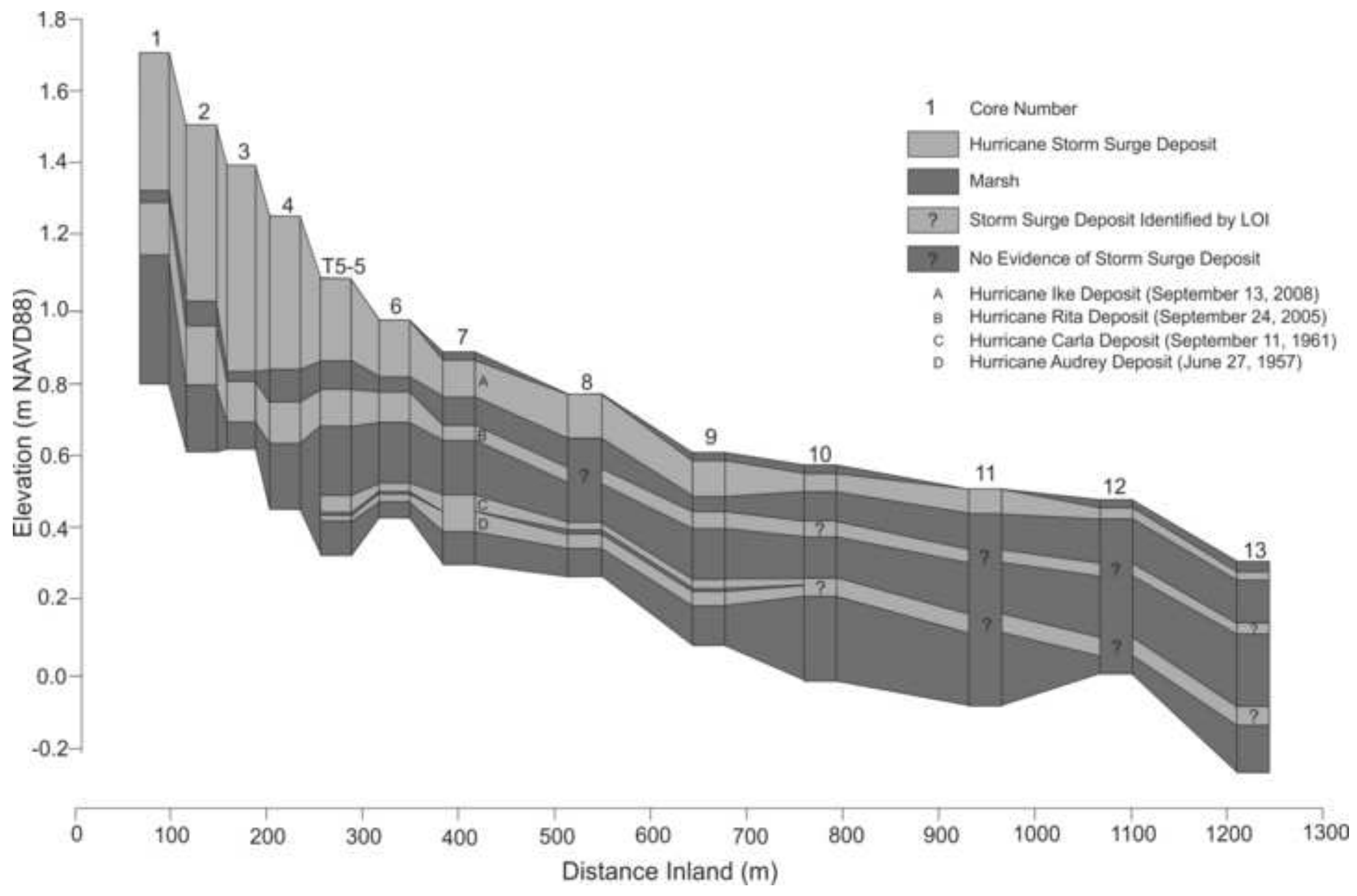



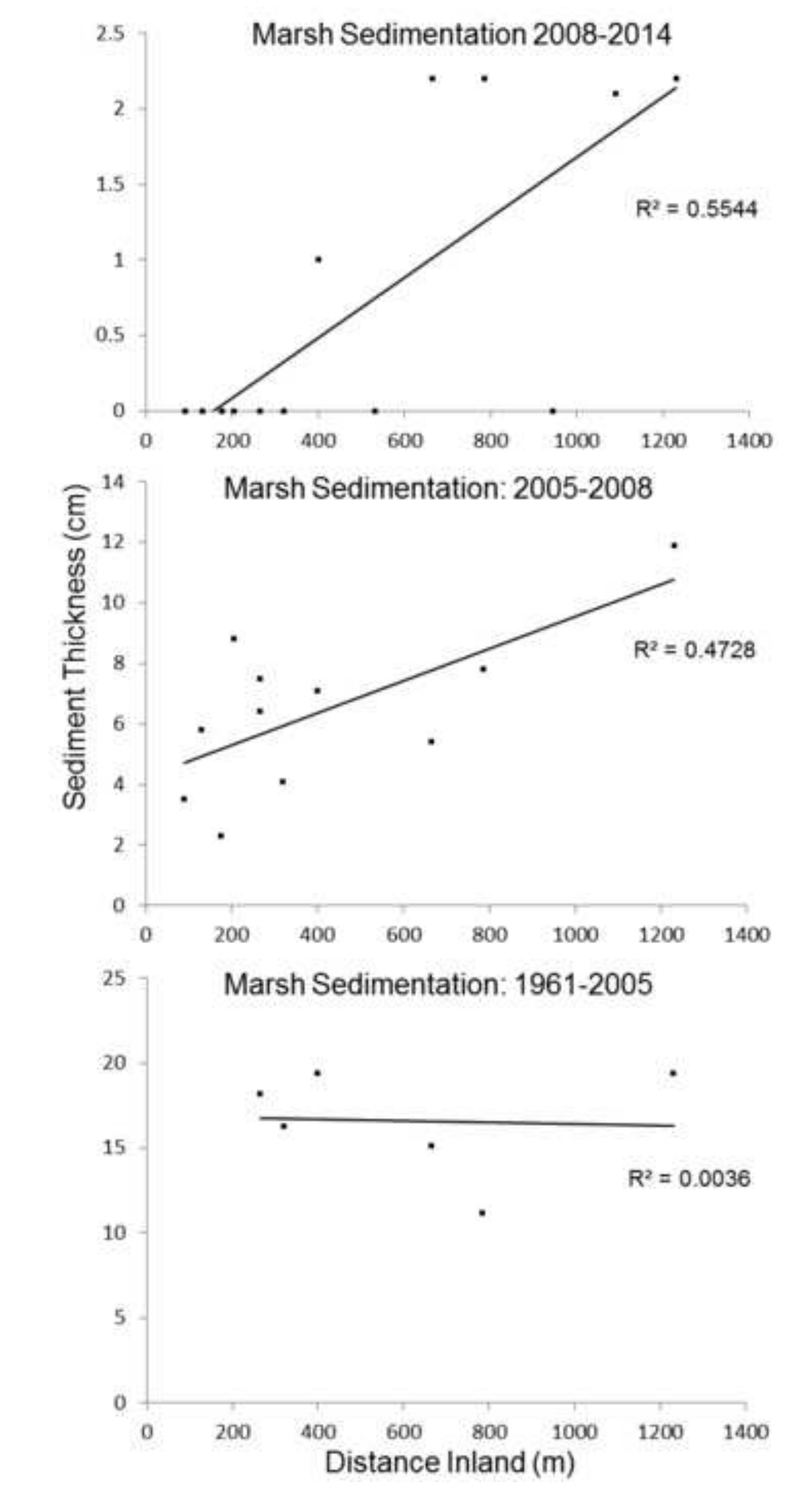

Figure 11 (Greyscale)

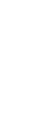

.

gure 11 (Greyscale)

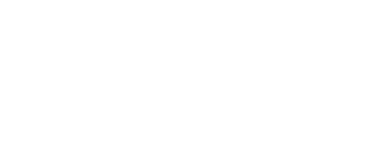

